UNIVERSIDADE DE SĀO PAULO
FFCLRP - DEPARTAMENTO DE BIOLOGIA

PROGRAMA DE PÓS-GRADUAÇĀO EM ENTOMOLOGIA

Análise dos comportamentos envolvidos na organização social e no processo de enxameio de Parachartergus fraternus (Hymenoptera, Polistinae, Epiponini).

\author{
Sidnei Mateus
}

Tese apresentada à Faculdade de Filosofia Ciências e Letras de Ribeirào Preto da USP, como parte das exigências para a obtenção do título de Doutor em Ciências, Área: Entomologia.

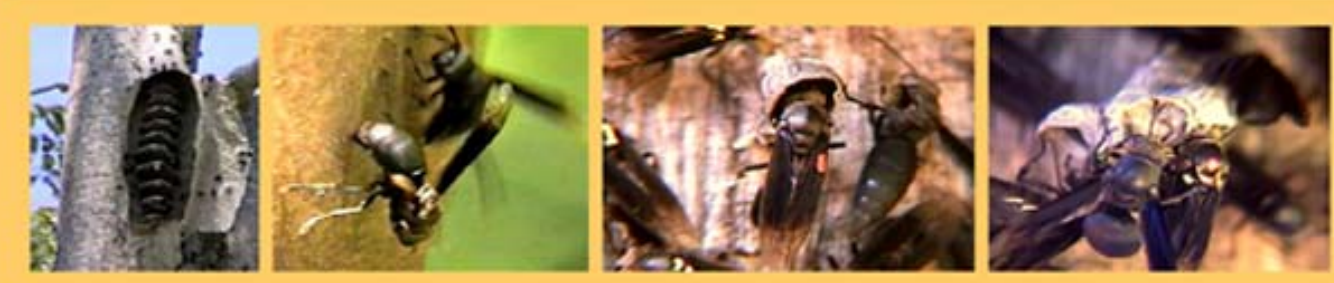

Ribeirào Preto - SP 2005 


\author{
UNIVERSIDADE DE SÃO PAULO \\ FFCLRP - DEPARTAMENTO DE BIOLOGIA \\ PROGRAMA DE PÓS-GRADUAÇÃO EM ENTOMOLOGIA
}

\title{
Análise dos comportamentos envolvidos na organização social e no processo de enxameio de Parachartergus fraternus (Hymenoptera, Polistinae, Epiponini).
}

\section{Sidnei Mateus}

Tese apresentada à Faculdade de Filosofia Ciências e Letras de Ribeirão Preto da USP, como parte das exigências para a obtenção do título de Doutor em Ciências, Área: Entomologia.

Ribeirão Preto - SP 


\author{
UNIVERSIDADE DE SÃO PAULO \\ FFCLRP - DEPARTAMENTO DE BIOLOGIA \\ PROGRAMA DE PÓS-GRADUAÇÃO EM ENTOMOLOGIA
}

Análise dos comportamentos envolvidos na organização social e no processo de enxameio de Parachartergus fraternus (Hymenoptera, Polistinae, Epiponini).

\author{
Sidnei Mateus \\ Orientador: Prof. Dr. Ronaldo Zucchi
}

Tese apresentada à Faculdade de Filosofia Ciências e Letras de Ribeirão Preto da USP, como parte das exigências para a obtenção do título de Doutor em Ciências, Área: Entomologia.

Ribeirão Preto - SP 
Dedicatória 
A meus pais

Saturno e Yolanda,

pelo exemplo constante.

E especialmente,

à Sôninha, Verônica e Lucas,

pelo apoio e compreensão

Dedico 
Ao Prof. Dr. Ronaldo Zucchi pela oportunidade e incentivo para a realização deste trabalho, pela orientação, amizade e confiança.

Ao Prof. Dr. Fernando Barbosa Noll, pela amizade e incentivo.

À Profa. Dra. Luci Rolandi Bego, pela oportunidade.

Ao Prof. Dr. Evandro Camillo, pela amizade e apoio.

À Profa. Dra. Eunice Vieira da Silva Matos, pela leitura da tese.

Aos colegas de laboratório do Setor de Ecologia e Evolução da FFCLRPUSP, pelo apoio e amizade.

Aos colegas Austríacos: Stefan, Michael e Veronika M. Schmidt, pela amizade e apoio.

Aos colegas Japoneses: Kudô, Eri e Ryo pela amizade.

Aos meus colegas funcionários do Departamento de Biologia: José Amílcar, José Carlos, Laércio, Maria Gonçalves (Cidinha), Maria Isabel (Bel), Renata, Miriam Cristina, Isabel, Carlos, Suzi, Ricardo Barosela e Hertz pela amizade.

A todas as pessoas residentes na Furna São Pedro em Pedregulho, SP, pela permissão de trabalho e amizade.

Ao Régis Giolo e família pela ajuda e amizade, especialmente por preservar ninhos de vespas.

Aos Docentes do Departamento de Biologia pela amizade e apoio.

À Coordenação do Curso de Pós-Graduação em Entomologia.

À Universidade de São Paulo, Campus da USP de Ribeirão Preto pela oportunidade oferecida.

À Faculdade de Filosofia Ciências e Letras de Ribeirão Preto - USP, pela oportunidade.

Meus sinceros agradecimentos a todos que de forma altruísta contribuíram para a realização deste trabalho. 


\section{RESUMO}

A fundação por enxameamento e poliginia (múltiplas rainhas funcionais) são características marcantes nas vespas da tribo Epiponini, dominantes na região Neotropical. A diversidade na diferenciação entre castas no grupo é interessante. É evidente a distinção entre rainhas e operárias nos gêneros basais, contrastando com a presença de intermediárias (fêmeas não inseminadas com ovários desenvolvidos) nos gêneros mais derivados. Os objetivos deste trabalho foram conhecer aspectos relacionados ao processo de migração forçada, à organização social inter e intra-castas em Parachartegus fraternus. Certificar-se dos aspectos referentes ao fenômeno da oligoginia cíclica. Os principais resultados foram: $O$ processo de reprodução colonial é um evento de difícil observação. Desse modo, para estudá-lo em detalhes este estudo se valeu da análise de enxameagens provocadas pela remoção das estruturas do ninho de seis colônias naturais de Parachartegus fraternus "absconding swarms" (Richards \& Richards, 1951). Após essa intervenção observaram-se os seguintes eventos: dispersão majoritária dos adultos, retorno gradativo dos indivíduos aos remanescentes do ninho (área do substrato revestida com material vegetal) e sua permanência no local até o início da migração. Esse evento teve início com muitas vespas deixando o local de agregação anteriormente mencionado, voando ao redor de árvores e arbustos próximos, freqüentemente pousando nas folhas e retornando ao local do ninho original. O comportamento de arrastar o abdômen no substrato "dragging behavior" (Naumann, 1975) observado desde a remoção do invólucro e dos favos intensificou-se com o aumento dos referidos vôos. Como esse ato envolve a deposição de substâncias atrativas (Jeanne $1975,1981)$ sobre vários pontos (principalmente folhas) estabelece-se uma trilha "trail making" (Naumann, 1975; Jeanne, 1975, 1981) que atrai outras vespas e, inclusive, novas escoteiras. Essas novas escoteiras, reforçando as marcas anteriores, aumentam a eficiência da trilha que, posteriormente, sendo percorrida pela principal onda migratória guia o enxame propriamente dito até 
o novo local de nidificação. No caso de $P$. fraternus, escoteiras foram encontradas em diferentes locais (pré-seleção do local do novo ninho). Entretanto, no local definitivamente selecionado, as escoteiras, repetidamente, além de arrastar o abdômen, depositavam veneno no substrato diferenciando o local de estabelecimento das marcas deixadas no curso da trilha (finalização do caminho químico). Estabelecida a trilha, a migração difusa e massal definitiva ocorre rapidamente. A eficiência do método migratório é notável. Terminada essa fase, no local do ninho antigo restam poucos indivíduos e, principalmente, os machos. Finda a fase migratória operárias retornam várias vezes ao local em que esteve estabelecida a antiga colônia. Essas visitas servem para coletar materiais que serão reutilizados na construção do novo ninho. As rainhas tiveram uma existência pacífica entre elas, no entanto, ficou evidente a competição ligada a postura. A detecção de oofagia diferencial entre as rainhas é importante por ser ela altamente competitiva. A principal função das rainhas é a postura, em colônias estáveis, supostamente, elas inibem a postura de intermediárias. As operárias estão envolvidas no processo de eliminação de rainhas que ocorre de forma gradual ou abrupta. As rainhas supostamente perdem a dominância feromonal ao longo do ciclo colonial e são agredidas por operárias e eliminadas gradualmente da colônia. A eliminação de forma abrupta ocorreu durante o préenxameio e estabelecimento, provavelmente algumas rainhas são feromonalmente reconhecidas como mais fértil e dominante e não são eliminadas. A oligoginia cíclica foi confirmada, restando apenas uma rainha em uma das colônias, e somente depois do desaparecimento de todas rainhas identificadas novas rainhas iniciaram posturas. Em colônia onde foram retiradas rainhas e intermediárias em postura não foi observado novas rainhas em um período de 30 dias, a orfandade refletiu na arquitetura do ninho. As intermediárias foram flexíveis na realização de tarefas ligadas ao forrageio, construção do ninho e enxameio. Porém, a postura de ovos pelas intermediárias pareceu ser facultativa e oportunista dependente da fase e do número de rainhas na colônia, possivelmente, a postura das intermediárias tenha sido suprimida por feromônios de rainhas. As intermediárias foram ativas durante o 
estabelecimento de algumas colônias, competiram com as rainhas por células para realizar posturas e fizeram oofagia diferencial em ovos de rainhas. No entanto não foi observada nenhuma agressão em intermediárias. Foi observado um caso de substituição da rainha por operária. A fêmea que se tornou rainha foi observada anteriormente em diversas tarefas na colônia ligadas a construção e manutenção. Durante o estabelecimento e a monoginia da colônia, a operária se manifestou como intermediária. No total foi observada por 192 dias desde que foi marcada com código de cores. Assim, em espécies com baixa diferenciação entre as castas, com determinação pós-imaginal, todas as operárias tem possibilidade de se tornar rainha dentro de uma determinada faixa etária. 


\section{SUMMARY}

New nests foundation through swarming and polygyny (multiple functional queens) stand among the most remarkable characteristics of the Epiponini wasps that dominantly thrive in the Neotropics. On morphological grounds inter caste differences range from virtually absent to fair distinctness. Moreover, curious presence of intermediate (uninseminated, ovary-developed females, cf. Richards \& Richards, 1951) in most genera add complex characteristics to the Epiponini social organization. For obvious reasons natural swarming in these wasps has been seldom recorded. On this account to gain new insights on the swarming process it was provoked and studied in six colonies of Parachartergus fraternus by removing nests principal structures. On the other hand, need of observing the experimental colonies carefully lead us to approach the wasps social organization through intensive direct observations. In this case, especial attention was paid to the mechanisms leading to cyclical oligogyny, as the mechanisms underlying queen's selection, queen's competition over egg laying, role of the intermediates, etc., can be adequately approached through direct observations, only. After nest structures removal, majority of the wasps dispersed widely. Their return to the nests remains was invariably gradual, and not organized. So, after using the nest remains as the main aggregation area for a period, migration procedures to o new site started with many wasps departing from the aggregation spot and flying around. Most of these flying wasps used to land on the neighboring vegetation and to return thereafter to the aggregation spot. Abdomen dragging behavior (Naumann, 1975), as observed to occur right after nest's structures removal is intensified. Through such peculiar behavior the wasps (scout wasps) add special scents to the dragged spot (Jeanne, 1971, 1975) of which sequential combination (trail making, cf. Naumann, 1975) guides the wasps to the previously chosen new nest site. Efficiency of the scented spots is certainly increased as newcomers scout wasps often perform additional dragging behavior on them. In the course 
of the observations it could be ascertained that the scout wasps often gather over several spots (nest site pre-selection). Even though abdominal dragging on such spots is intense, it's important to stress that only of them received venom deposition through frequent sting acts on the substratum. This may indicate venom deposition signals towards migration end, as odors in it should be different than those left by the dragging behavior. As soon as the scent trail is set definite migration occurs of which efficiency is remarkable as suggested by very low number of wasps left behind on the old nest remain. Among these prevalence of males is notorious. Seemingly they are not able to follow the scent trail as the females do so efficiently. In addition, after the bulk of the population arrives to the new nest site, the scout start returning to the old spot to collect materials to be promptly used in the newly started constructions.

In general, queens were quite indifferent one another. However, mild and often non explicit competition trends may take place in the events underlying egg laying. Among such, frequent cases of differential oophagy were recorded what probably points out towards competitive mechanisms. More active queens leave more descendants, supposedly. Queen's certainly more evident function relates to oviposition. For such, besides likely competition as afore mentioned it seems also probable that queens can pheromonally inhibit intermediates ovipositions. The mechanism leading to cyclical oligogyny is mediated by the workers. Indeed, groups of workers or even isolated workers respond for the majority of the queen direct attacks. Moreover, mentioned attacks may appear gradually or suddenly. Reasons for such attacks remain unknown. Apparently, in the course of aging the queens may loose their distinctive pheromones what may enhance antagonisms and attacks. Obtained results support cyclical oligogyny. Through it a given colony reached monogyny. In general it was only after queenlessness that the newly produced gynes started ovipositing. In a colony of which queens and intermediates were removed, no queens appeared after 30 days. Orphan colonies develop nests structural abnormalities. Concerning foraging, nest construction and swarming, intermediates were socially flexible. However, their oviposition involvement is seemingly 
opportunistic as it depends on colony development phase, and number of present queens. It seems likely that intermediates ovipositions can be pheromonally regulated by the queens. In some cases they were more active in the course of colony establishment. Despite, no aggressions were recorded against the intermediates; they were seen eating some of the queens laid eggs. In a given instance a worker substituted a queen. Such worker had been previously recorded in tasks related to nest construction and nest keeping. Besides, as her behavior could be albeit intermittently tracked for 192 days, of which period covered from colony establishment until monogyny through polygyny, it could be ascertained that she invariably performed worker-like functions, that is, she was never seen playing even the role of an intermediate female. However, subsequent dissections performed on the nest population proved that she was the only ovary-developed and inseminated female in that particular colony. This is the most extreme case of caste flexibility ever recorded among the Epiponini wasps. Apparently, incipient caste differences allied to likely occurrence of pos-imaginal caste development in $P$. fraternus triggered hidden survival mechanisms allowing present especial case of worker-queen substitution event. 


\section{A- INTRODUÇÃo}

Nos Hymenoptera, a família Vespidae é composta por seis subfamílias: Euparagiinae, Masarinae, Eumeninae, Stenogastrinae, Polistinae e Vespinae (Fig. 1). Nesta família, ocorrem praticamente todos os quatro estágios de organização social citados por Wilson (1971) sendo que três das subfamílias (Stenogastrinae, Polistinae e Vespinae) apresentam espécies eussociais (Carpenter, 1982; Carpenter \& Rasnitsyn, 1990; Carpenter, 1993).

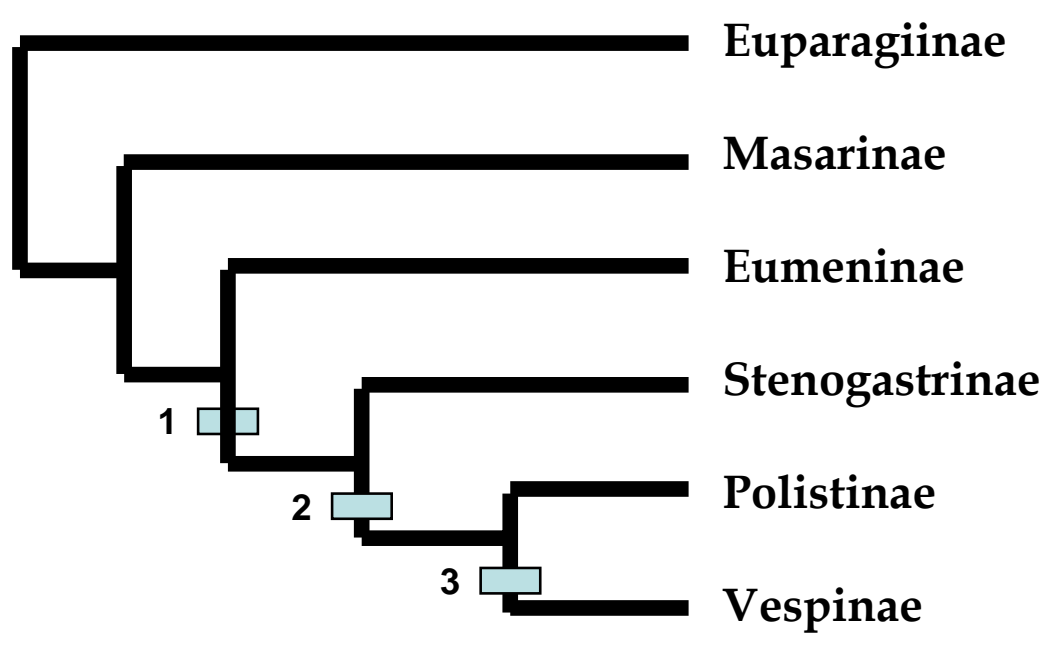

Figura 1. Filogenia de Vespidae, Carpenter (1993), indicando: (1) origem da eussocialidade facultativa ou temporária; (2) origem da eussocialidade permanente com monoginia de curto período; (3) origem da eussocialidade avançada. (cf. Noll, 2000, inclusive referências).

Os Euparagiinae, Masarinae e Eumeninae são tipicamente solitários, porém evidências de comportamento comunal foram encontradas em Masarinae e Eumeninae (Trimeria howardi cf. Zucchi et al., 1976 e em Zethus spp., cf. WestEberhard, 1987; Drumond, 1986) respectivamente. Nos Stenogastriinae a fundação do ninho é solitária, podendo ocorrer com a presença de mais de uma fêmea. Nessa subfamília não há espécies que apresentem comportamento tipicamente eussocial, isto é, todos os indivíduos são potencialmente 
reprodutores e não há evidências de casta operária (Turillazzi, 1991). Em decorrência disso os Stenogastrinae podem ser considerados primitivamente eussociais, em que diferenças eto-fisiológicas parecem ser a única forma de distinguir poedeiras de operárias (Sakagami \& Yoshikawa, 1968; Yoshikawa et al., 1969; Hansel et al., 1982).

Nos Vespinae e nos Polistinae, encontram-se os grupos eussociais. Embora isso se aplique perfeitamente para o caso de colônias maturas é preciso lembrar que a maioria dos Vespinae (exceto Provespa anomala, cf. Matsuura, 1991), Polistini, Mischocyttarini, Parapolybia, Belonogaster e alguns Ropalidiini apresentam uma fase preferencialmente solitária durante a fundação colonial. Assim sendo, os Vespidae realmente eussociais são apenas aqueles cujas novas colônias são produzidas por enxames "swarm-founding" Polistinae; cf. Hölldobler \& Wilson, 1977; Jeanne, 1980, a saber, todos os Epiponini e alguns Ropalidiini (Figura 2). Evidentemente, uma apreciação sociobiológica do assunto é ainda matéria pendente. O próprio termo eussocial sensu Michener, 1969 não tem para as vespas a mesma conceituação que tem para as abelhas. Algumas tentativas de padronização foram tentadas (Kukuk, 1994; inclusive referências). Na prática, face à complexidade do assunto (táxons que apresentam diferentes padrões de organização social à medida que o ciclo colonial progride; alta diversidade social em certos táxons por ex., Ropalidia formosa que apresentou evidências de espécie solitária, cf. Wenzel, 1987 etc.), o uso dessas tentativas tem sido bastante limitado.

As vespas sociais formam dois grupos distintos de acordo com a maneira de fundação de seus ninhos (Jeanne, 1980). O primeiro grupo é formado pelas fundadoras independentes, o ninho é iniciado por uma rainha inseminada. Nos Polistinae com fundação independente, uma ou mais fêmeas inseminada podem, posteriormente unir-se à fundadora. O segundo grupo é formado pelas vespas enxameadoras, no qual uma colônia é iniciada por uma ou várias rainhas e um grupo de operárias. As vespas enxameadoras ocorrem em quatro clados: os Vespinae, gênero Provespa mais os Ropalidiine, gênero Ropalidia (somente algumas espécies) e Polybioides no velho mundo, e todos os 19 gêneros 
Neotropicais da tribo Epiponinii (Fig. 2). De acordo com cladograma apresentado (Fig. 2), as vespas fundadoras independentes tiveram um ancestral comum como em todas vespas eusociais. E a característica de enxamear esteve envolvida independentemente pelo menos quatro vezes (Wenzel \& Carpenter, 1994) (Fig. 2).

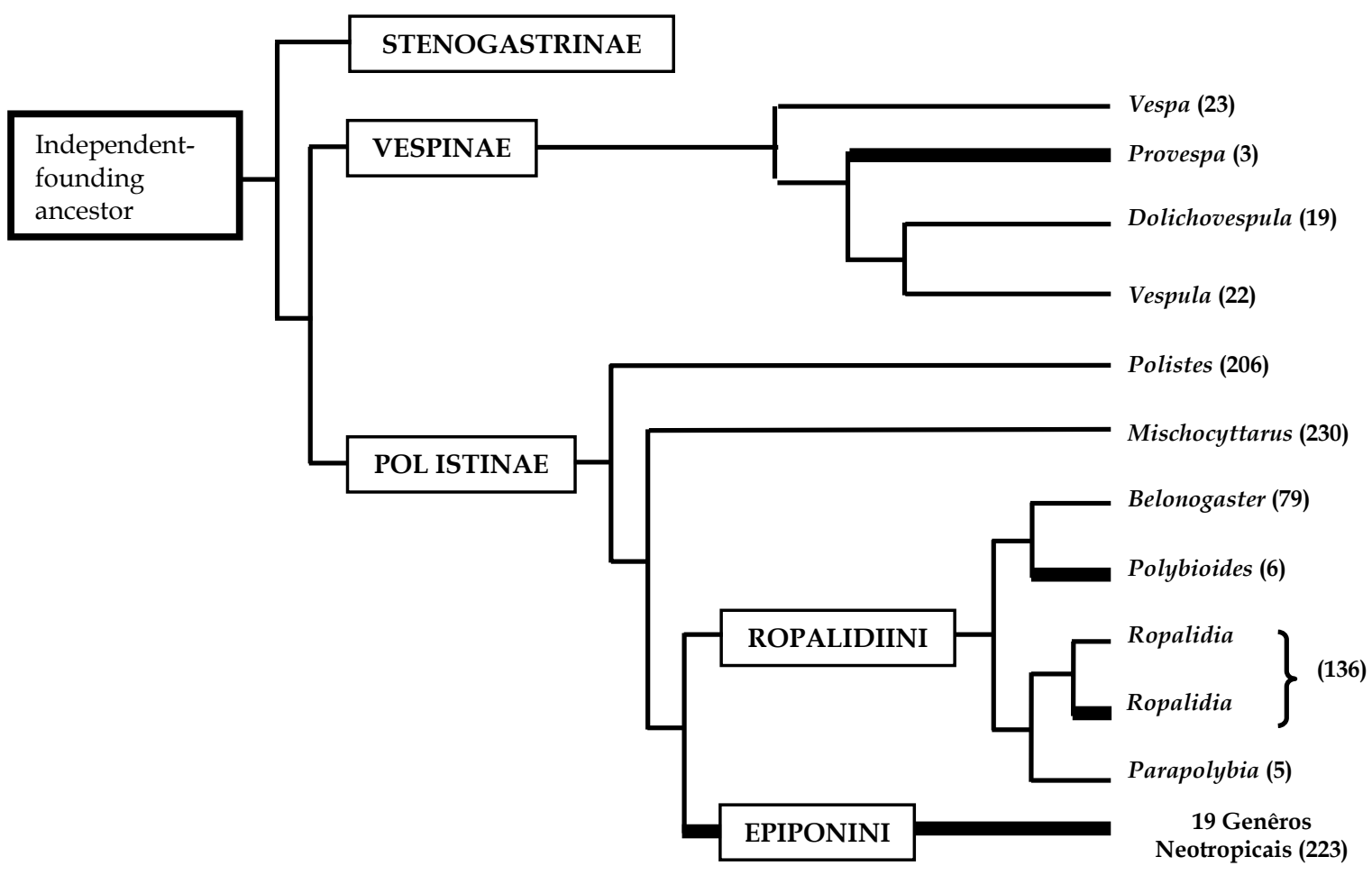

Figura 2. Cladograma dos Vespidae eusociais (modificado de Jeanne, 2003 Carpenter, 1991, 2004) mostrando fundadores independentes (linha fina), e vespas enxameadoras (linha grossa), entre parênteses o número de espécies.

O grupo monofilético Neotropical formado pela tribo Epiponini se caracteriza pela variação no número de rainhas durante o ciclo da colônia. Em decorrência, em certos casos, e por um certo período, pode ocorrer apenas uma (monoginia) ou poucas rainhas (oligoginia) na colônia (West-Eberhard, 1973, 1978a; Richards, 1978; Jeanne, 1980, 1981). Desse modo, o grupo tem sido caracterizado como permanentemente (ou primariamente) poligínico. Entretanto, a marcante poliginia ao longo dos ciclos coloniais dos Epiponini 
indica que o ancestral comum do grupo apresentaria poliginia de longoperíodo.

A tribo Epiponini é composta por 19 gêneros (Carpenter, 2004; Tabela 1). Embora a distribuição geográfica do grupo seja bastante ampla, pois seus representantes ocorrem da Argentina até os Estados Unidos, é nos ecossistemas brasileiros que os Epiponini atingem sua diversidade máxima, tanto ao nível genérico quanto específico. No Brasil, os Epiponini são ecologicamente dominantes e se caracterizam por notável irradiação adaptativa (Jeanne 1975a, 1980).

Tabela 1 . Classificação e distribuição geográfica dos Polistinae (cf. Carpenter 1993, 2004

\begin{tabular}{|c|c|c|}
\hline TRIBO & GÊNEROS & DISTRIBUIÇÃO \\
\hline Polistini & Polistes & Cosmopolita, exceto Nova Zelândia \\
\hline Mischocyttarini & Mischocyttarus & $\begin{array}{l}\text { Argentina até sudeste e oeste dos } \\
\text { Estados Unidos, Columbia Britânica }\end{array}$ \\
\hline Ropalidiini & Ropalidia, Parapolybia, Polybioides, Belonogaster & $\begin{array}{lcr}\text { Austrália, } & \text { África } & \text { sub-Sahara, } \\
\text { Península } & \text { Arábica, } & \text { Trópicos } \\
\text { Orientais, China, Coréia, Japão, Irã, } \\
\text { África Equatorial, Índia }\end{array}$ \\
\hline $\begin{array}{l}\text { Epiponini } \\
\text { (= Polybiini, auct.) }\end{array}$ & $\begin{array}{l}\text { Apoica, Agelaia, Angiopolybia, Pseudopolybia, } \\
\text { Parachartergus, Leipomeles, } \\
\text { Chartergellus, } \\
\text { Nectarinella, Protopolybia, Polybia, Protonectarina, } \\
\text { Charterginus, Chartergus, Brachygastra, Epipona, } \\
\text { Synoeca, Asteloeca, Clypearia, Metapolybia }\end{array}$ & $\begin{array}{l}\text { Argentina até sudeste dos Estados } \\
\text { Unidos (representantes de Polybia e } \\
\text { Brachygastra ocorrem no Texas e } \\
\text { Arizona) }\end{array}$ \\
\hline
\end{tabular}

O gênero Parachartergus, enfoque principal deste trabalho, pertence à subfamília Polistinae. Segundo Richards (1978) o gênero conta com 17 espécies descritas, entretanto, a bionomia de muitas delas é pouco conhecida. Parachartegus fraternus habita preferencialmente as áreas de cerrado e, dentro do gênero, é a espécie que apresenta distribuição geográfica mais ampla, ocorrendo desde a Guiana Francesa até Minas Gerais (Richards, 1978) e São Paulo (Mateus, et al., 2004). A diferenciação morfofisiológica das castas é incipiente na maior parte do ciclo colonial (Richards, 1978; Noll, 2000; Mateus et al., 2004; Saito et al., 2004). Além disso, essa espécie se caracteriza pela abundante presença de 
intermediárias (cf. Richards \& Richards, 1951, fêmeas com desenvolvimento ovariano consistente e não inseminadas) durante a maior parte do ciclo colonial.

Desde os trabalhos pioneiros de H. de Saussure, A. Ducke, H. von Ihering, O. W. Richards, etc. (cf. revisão, Carpenter 2004) vários detalhes da bionomia das vespas da tribo Epiponini (Polybiini auct., cf. Carpenter, 1993), tais como, marcante variabilidade da arquitetura dos ninhos, ocorrência de múltiplas rainhas (poliginia), reduzida diferenciação inter castas, propagação de colônias por enxameio, ocorrência de intermediárias, etc., têm atraído a atenção de muitos pesquisadores. Mais recentemente, embora sob novos enfoques, o mencionado interesse ingressa numa fase fortemente ascendente, a saber:

1- a expressiva variabilidade dos Epiponini impulsionando estudos da filogenia. Esse tipo de abordagem tem progredido muito e, além de organizar o tratamento dos tradicionais aspectos morfológicos, tem se preocupado também com detalhes comportamentais (Carpenter, 1991, 1993; Wenzel, 1993; Wenzel \& Carpenter, 1994; Noll et al., 2004). Graças a isso, para as vespas em geral e para Epiponini em particular, tem-se hoje um modelo filogenético consistente. Especialmente para um grupo com alta diversidade bionômica, a importância de se poder contar com bases filogenéticas seguras reverte-se em incentivo para inúmeros tipos de abordagens evolutivas. Para isso, basta lembrar que as abordagens visando compreensão (mesmo parcial) dos mecanismos envolvidos na evolução das adaptações complexas (padrões de organização social, tipos de arquitetura de ninhos, mecanismos de comunicação, etc.) são essencialmente exercícios comparativos que se beneficiam do uso de caracteres apresentando estados diversificados. Segundo Brockmann \& Dawkins (1979) essa situação favorável fica ainda mais facilitada se a diversidade, além de expressiva, puder, também, ser organizada em séries de transformações plausíveis. A freqüente detecção dessas características favoráveis nas vespas (Vespidae, cf. Carpenter \& Rasnitsyn, 1990), fizeram desses insetos um grupo paradigmático e ideal para fundamentar, entre outros aspectos, estudos de evolução do comportamento social (Michener, 1990; West-Eberhard, 1991). Evidentemente, todo o sucesso já 
conseguido seria duvidoso ou falho sem as mencionadas bases filogenéticas seguras.

2- emergência e abrangência da seleção por parentesco ("inclusive fitness", cf. Hamilton 1963; 1964 a \& b; 1972; "kin selection", cf. Maynard Smith, 1964). Numa colônia eussocial monogínica a rainha convive com um grande número de indivíduos não reprodutores (operárias). O modelo proposto por Hamilton visa explicar as razões pelas quais as operárias contribuem na criação de novas irmãs, em vez de produzir suas próprias crias. Considerando que nos Hymenoptera o genoma haplodiplóide é ancestral em relação à eussocialidade, Hamilton ponderou que o grupo estaria pré-disposto à eussocialidade em razão do elevado relacionamento gênico entre as irmãs acarretado pela haplodiploidia. Entretanto, como na poliginia o "fitness" ganho via cooperação diminui em proporção ao crescimento do número de rainhas, isso levou Hamilton (cf. Hamilton 1972: 217) a expressar suas próprias dúvidas quanto à universalidade da "kin selection" como promotora do altruísmo, ao afirmar: "In my opinion the polygyny in Polybiini (for example) and its contrast with organization of Polistes and Vespinae, provides the most testing difficulty for the interpretation of the social insect pattern which is offered in this review".

3- a oligoginia cíclica e a solução do dilema de Hamilton. Lembrando que os Polybiini mencionados acima, correspondem atualmente aos Epiponini (cf. Carpenter, 1993; 1997), é importante enfatizar que a dúvida explicitada por Hamilton permaneceu vigente até que os trabalhos de West-Eberhard (1978 a, b; 1981) referentes à bionomia de Metapolybia aztecoides contribuíssem para elucidar os aspectos envolvidos na questão. De fato, partindo-se de uma colônia madura (normalmente poligínica), conforme o ciclo colonial progride, a população de rainhas decresce (fase oligogínica) podendo reduzir-se a uma só (fase monogínica). Além disso, como a produção de novas rainhas só ocorre em colônias maduras, isto é, mono e/ou oligogínicas, as rainhas-filhas serão altamente aparentadas entre si ("full sisters", ou "super sisters", cf. Page \& Laidlaw, 1988), pois a haplodiploidia aliada, no caso, aos efeitos da poliginia, promove a ocorrência de linhagens de operárias geneticamente próximas devido 
ao estreito vínculo matrifilial. De acordo com os resultados obtidos, existem fortes evidências de que o modelo descrito para Metapolybia possa ser generalizado para outros Epiponini (Noll \& Zucchi, 2002; Noll et al., 2004; Nascimento et al., 2004; Kudô et al., 2005 etc.). Desse modo, de maneira muito convincente, esse quadro insere os Epiponini nos postulados da "kin selection". Ademais, o padrão encontrado em Metapolybia aztecoides, além de explicar outros casos afins de monoginia descritos na literatura (Richards \& Richards 1951: Polybia micans, Po. bistriata, Po. bicytarella, Po. catillifex), contribuiu também para evidenciar o mesmo fenômeno em vários outros taxa (West-Eberhard, 1978b; Forsyth, 1978; Jeanne, 1991; Shima et al., 1994; Strassmann et al., 1989, 1997), embora, nem sempre, o número de rainhas chegue à monoginia. Cunhou-se, assim, o termo oligoginia cíclica para especificar que, durante a ontogênese, uma colônia de Epiponini pode apresentar alternância entre alto e baixo número de rainhas, com produção de rainhas-filhas apenas na etapa em que as rainhasmães estejam ocorrendo em freqüências reduzidas. A utilização de técnicas biomoleculares contribuiu para validar o modelo em questão, pois vários trabalhos têm revelado o elevado parentesco ocorrente entre operárias de uma mesma colônia (Queller \& Strassmann, 1998, 1993; Hughes et al., 1993; Solís et al., 1998; Strassmann et al., 1991, 1997, 1998).

4- a possível origem e evolução dos característicos que promovem a singularidade dos Epiponini. Como já mencionado essa singularidade deriva da ocorrência dos seguintes caracteres: alta diversidade arquitetural dos hábitos de nidificação, poliginia, castas pouco diferenciadas, reprodução de colônias por enxameio e presença de fêmeas intermediárias.

Consensualmente admite-se que as explicações para as mencionadas singularidades de Epiponini derivam de dois cenários: a eussocialidade das vespas originou-se nos trópicos (Evans \& West-Eberhard, 1970); onde as formigas são os mais importantes predadores das colônias (Richards \& Richards, 1951). A partir dessas premissas, parece adequado considerar que os característicos mais relevantes da bionomia dos Epiponini (cf. acima), seriam resultantes de adaptações que acabaram por aperfeiçoar os meios de defesa 
contra o mencionado tipo de predação (Richards, 1971, 1978; Jeanne, 1975a, 1979; Starr, 1990; Simões et al., 1996). Desse modo, a diversidade de tipos de ninhos, por exemplo, sugere evolução de respostas adaptativas que além da defesa eficiente contra formigas proporcionaram, também, economia de trabalho e otimização dos materiais usados na construção dos ninhos (Jeanne, 1975a; Wenzel, 1991, 1998). Como reforço a essa interpretação, é importante mencionar que: a- a taxa predatória pelas formigas é significativamente maior nos trópicos (Jeanne, 1979); b- vespas que constroem ninhos pedunculados (estelocítaros) revestem essa estrutura com substâncias repelentes a formigas, produzidas pelas glândulas abdominais e que são posteriormente espalhadas com o órgão de Van der Vecht (Jeanne, 1970, 1972; Starr, 1990, inclusive referências); cMetapolybia aztecoides que constrói ninhos apostos ao substrato (astelocítaros), deposita substâncias repelentes ao redor do invólucro colonial ("scent-trail diversion", cf. West-Eberhard, 1989); d- Nectarinella xavantinensis, que não possui o órgão de Van der Vecht (Smith et al., 2001) deposita pequenas porções de material viscoso na entrada do ninho e ao redor do invólucro (Mateus \& Noll, 1997).

Seguindo argumentação semelhante, outras peculiaridades dos Epiponini (cf. acima) ficam também mais fáceis de interpretar alegando-se os mesmos agentes causais. Frente a um ataque de formigas o abandono do ninho pela rápida migração da população adulta é, certamente, uma importante estratégia.

Desse modo, a eficiência e a segurança do comportamento migratório forçado ficariam aumentadas com a poliginia, cujas características essenciais derivam de um processo de transformação que levou à seleção de rainhas morfologicamente pouco diferenciadas (menor massa corpórea, maior facilidade de voar) e numericamente abundantes (maiores oportunidades para o restabelecimento das atividades da colônia num novo local de nidificação). Dentre as peculiaridades componentes da bionomia dos Epiponini, citou-se a presença de fêmeas intermediárias. Elas foram registradas primeiramente por Richards \& Richards (1951) que, a partir de suas características essenciais as definiu como "fêmeas não inseminadas e portadoras de desenvolvimento 
ovariano consistente, em colônias normais". A função das intermediárias nas colônias de Epiponini é assunto muito debatido. Richards (1971) as considera como possíveis produtoras de ovos tróficos atribuindo-lhes, inclusive, a produção de machos. Entretanto, Forsyth (1978), West-Eberhard (1978a) e Gastreich et al. (1993), consideram-nas como rainhas jovens e, portanto, ainda não inseminadas. Richards (1971) e West-Eberhard (1978), adicionam que o desenvolvimento ovariano das intermediárias relaciona-se com o número de rainhas presentes na colônia, isto é, na presença de poucas rainhas elas apresentam ovários mais desenvolvidos e vice-versa. Entretanto, mesmo levando-se em conta que isso tenha sido demonstrado em alguns táxons (Noll, 1995; Noll \& Zucchi, 2000, 2002; Noll et al., 2004; Shima et al., 2003; Noda et al., 2003), parece claro que as conclusões acima não podem ser generalizadas. Para tanto, é suficiente lembrar que intermediárias nunca foram detectadas em certos táxons, (Simões, 1977; Sakagami et al., 1995; Noll et al., 1997; Baio et al., 1998), como é o caso da maioria das espécies que compõem o gênero Agelaia (exceto Agelaia lobipleura, cf. Richards, 1978). Ademais, a ausência de intermediárias se mantém mesmo sob monoginia temporária, em Apoica flavissima (cf. Shima et al., 1994). Além disso, análises morfométricas (Noll, 1995; Noll et al., 2004) mostraram que em certas espécies, as intermediárias relacionam-se mais estreitamente às operárias e que, em outras espécies, elas estão mais relacionadas às rainhas. As intermediárias podem ser encontradas em todas as fases do ciclo colonial em algumas espécies como, por exemplo, Protopolybia exigua (Simões, 1977; Noll et al., 1996) ou em fases específicas do ciclo colonial (Noll, 1995; Noll \& Zucchi, 2000, 2002; Noll et al., 2004). Tais fatos parecem indicar a ocorrência de três tipos de intermediárias: generalizadas (indistintamente presentes durante todo o ciclo de desenvolvimento da colônia), especializadas (presentes apenas em determinadas fases do ciclo da colônia) e, ausentes. Embora os fatores determinantes dessas possíveis categorias não sejam conhecidos, aparentemente, elas seriam derivadas da atuação dos mesmos fatores que se responsabilizam pelas diferenças ocorrentes entre rainhas e operárias, ou seja, as categorias de intermediárias seriam determinadas por 
peculiaridades nutricionais que se estabeleceriam durante o desenvolvimento larval (diferenciação pré-imaginal) e que se expressariam (ou não) dependendo do estado colonial. Outros detalhes referentes às intermediárias podem ser encontrados em Wheeler, 1986, 1991; Jeanne, 1995; Shima et al., 1998, 2003; O’Donnell, 1998; Noll \& Zucchi, 2000, 2002; Noll et al., 2004. Conforme mencionado, pouco se sabe sobre a função das intermediárias na colônia. Entretanto, em Protopolybia exigua (Simões, 1977), e Pr. acutiscutis (= P. pumila, cf. Naumann, 1970) os ovos por elas produzidos são comidos pela própria poedeira. Além disso, usando técnicas de biologia molecular, Hastings et al., (1998) demonstraram em Brachygastra mellifica que apesar da presença de um alto número de intermediárias, os machos são produzidos exclusivamente pelas rainhas. Desse modo, a função das intermediárias, poderia ser interpretada como ligada à distribuição de alimentos via funcionamento dos ovários e produção de ovos tróficos. Essa possibilidade já foi aventada para explicar casos afins ocorrentes em formigas dos gêneros Camponotus e Formica (Weyer, 1927, 1928, 1929; apud Sakagami et al., 1963), em Protopolybia acutiscutis (Naumann, 1970) e Meliponini (Zucchi, 1993, Zucchi et al., 1999). Como a principal fonte alimentar dos Epiponini é proteína animal que, por ser deteriorável, não permite estocagem, na eventualidade de uma migração forçada, os ovos tróficos das intermediárias, especialmente, na fase crítica de estabelecimento de um novo ninho após migração forçada, seria uma importante fonte emergencial de nutrientes. Nesse contexto, a origem das intermediárias somar-se-ia à origem das outras adaptações da bionomia dos Epiponini, também, supostamente selecionadas para enfrentar a ação predatória das formigas.

\section{5- o plano básico bivoltino e sua relação com a evolução e manutenção} da socialidade. Não sem razão, Polistes é considerado um "Key-genus". Não bastassem as características referentes às hierarquias de dominância (Pardi, 1942) e suas implicações na organização das sociedades animais, nem os estudos de Hamilton (1963, 1964a e b) que levaram à postulação dos princípios referentes a "inclusive fitness", recentemente, Hunt \& Amdam (2005) se valem de Polistes para propor um novo corpo de hipóteses que, pelas suas 
características, promete ser muito importante. Segundo essa proposta, a evolução das castas faria parte de um processo de remodelação que usaria os controles dos circuitos responsáveis pelo solitarismo (plano básico) na construção dos fenótipos sociais. A argumentação bastante convincente dos autores sugere que essa concepção simplifica as atuais ênfases baseadas em altruísmos, custo e beneficio, conflitos e cooperação etc., trazendo as explicações e implicações da aquisição de comportamento social para o comportamento da biologia do desenvolvimento.

6- o conceito de sociedades complexas. Numa recente e brilhante monografia (Jeanne, 2003) amplia, usando o modelo da organização social das vespas, o trabalho de Bourke (1999) sobre o assunto afim. No geral, o trabalho se preocupa com a questão: para onde a evolução conduziu as sociedades posteriormente à ultrapassagem da barreira solitarismo-eussocialidade. Cada um dos 4 grupos de insetos eussociais (térmitas, abelhas, formigas e vespas) exibe enorme diversidade de padrões de organização social. Esses padrões ocorrem em sociedades muito pequenas e estruturadas com simplicidade (Halictidae, Stenogastrinae etc.) até sociedades muito grandes e complexas (Apis, saúvas, térmitas etc.). Em comparação com o muito que tem sido feito para entender a evolução da eussocialidade, muito pouco esforço tem sido empregado no sentido de se entender tanto a diversidade dos tamanhos populacionais das colônias como também, o grau de integração social envolvido. Como o assunto tem sido tratado quase que exclusivamente com formigas, o autor argumenta sobre os benefícios que surgirão à medida que estudos detalhados da organização das vespas puderem ser analisados nos mesmos contextos. 


\section{A.1 - OBJETIVOS}

Evidentemente, é possível afirmar que cada uma das frentes (1-6) anteriormente mencionadas carece de substratos básicos e, entre estes situam-se especialmente os aspectos relacionados à observação direta dos comportamentos. No geral, estudos bionômicos em vespas da tribo Epiponini são escassos. Além da agressividade, podemos citar outras restrições ao pleno desenvolvimento de estudos nessas vespas, tais como: localização dos ninhos que freqüentemente ocorrem em locais de difícil acesso, presença do invólucro, abandono do ninho mediante interferências, ataques de formigas e de outros parasitas em ninhos submetidos a experimentação e a difícil adaptação em laboratório, etc. Desse modo, especial ênfase será dada ao processo de divisão colonial (processo de enxameio) e, também, a vários aspectos da organização social.

Embora a capacidade de enxamear seja comum a todos os gêneros de Epiponini, o processo de enxameagem tem sido pouco estudado tanto qualitativo, quanto quantitativamente. O próprio desenvolvimento do tema nos levou a abordar aspectos da organização social e seus determinantes, a saber: inter-relações rainhas - intermediárias - operárias, com ênfase nos comportamentos de posturas (rainhas e intermediárias), e também, longevidade das rainhas e intermediárias, verificar se o número de intermediárias presentes nas colônias é controlado pelo número de rainhas, além disso, verificar quando as intermediárias realizam posturas e qual o destino dos ovos por elas botados. Além disso, nos preocupamos em saber se as intermediárias participam da construção e defesa do ninho, se elas estão envolvidas em cuidados com a prole, se são capazes de forragear, etc. Também se objetiva saber quando e como ocorre a eliminação de rainhas, quais os fatores envolvidos neste fenômeno determinante da oligoginia cíclica. Outro aspecto que pretendemos estudar é a substituição de rainhas da colônia através da remoção de todas as fêmeas realizando posturas, rainhas e intermediárias, estudar os comportamentos da população durante a orfandade. 


\section{B - MATERIAL E MÉTODOS}

As seis colônias de Parachartergus fraternus (Gribodo) utilizadas para a realização deste trabalho foram coletadas e estudadas na área rural do município de Pedregulho SP, a saber: as colônias C1, C3 e C4 foram estudadas no local de ocorrência (Sítio Nossa Senhora Aparecida S 20¹5' W 047²7', altitude 1010 metros). A colônia C2 foi estudada na Furna São Pedro, Sítio Dona Júlia (S 20¹0' W 047²9') 690 metros de altitude. As colônias C5 e C6 foram coletadas na Furna São Pedro em 03/04/03 e 18/03/2004, respectivamente, e transferidas para o Campus da USP de Ribeirão Preto. Para isso, no período noturno, os ninhos foram envolvidos com tela de nylon e esta foi grampeada ao substrato original, sem danificar o invólucro. No novo local os ninhos foram fixados em troncos de árvores, preservando sua orientação original em relação ao sol. A tela de nylon foi retirada logo após a fixação do ninho ao novo local. O registro dos comportamentos envolvidos nas interações foram feitos após a remoção total ou parcial do invólucro e favos. Os ninhos de $P$. fraternus têm invólucro simples e favos horizontais pedunculados. Essas características facilitam observações diretas e registros em vídeo.

As observações iniciais para o estudo do enxameio forçado nas colônias C1, C2, C3, C4 e C6 foram contínuas, desde a remoção parcial das estruturas do ninho até o estabelecimento da população migrante no novo local, foi variável a duração em horas do pré-enxameio para cada colônia estudada (Tabela 2). Após o estabelecimento as colônias C1 e C2 foram observadas semanalmente durante um período de 272 e 247 dias consecutivamente. Essas observações visavam registrar aspectos comportamentais das rainhas, interações e longevidade. Com relação à colônia $\mathrm{C} 3$, durante o estabelecimento, o estudo foi direcionado ao comportamento das intermediárias e à eliminação das rainhas. Nesse período as intermediárias botando, rainhas eliminadas e operárias agressoras foram coletadas para posterior análise. Outro objetivo de estudo nesta colônia foi à 
remoção de todas as rainhas e intermediárias durante o estabelecimento para deixar a colônia órfã, e observar o tempo de produção de novas rainhas e testar a possível totipotência das operárias. A colônia C3 foi observada semanalmente por 30 dias. As colônias C4 e C6 foram utilizadas somente para o estudo do enxameio, os novos ninhos foram construídos em locais de difícil acesso para continuar os estudos de comportamento. Na colônia C5, não houve a remoção das estruturas do ninho, a colônia estava na fase de produção de operárias. $\mathrm{O}$ estudo foi inicialmente direcionado para as interações inter rainhas e, também, para as interações inter castas. Visando evitar o risco de abandono do ninho essas observações foram realizadas em dias intercalados, iniciaram em 24/04/03 e continuaram até 14/06/03 quando a população apresentou comportamento de pré-enxameio. Durante o estabelecimento e pós-estabelecimento algumas intermediárias tiveram os seus comportamentos detalhados (duração 17/06 a 05/08/2003). Posteriormente, elas foram coletadas, assim como, as rainhas que foram sendo eliminadas. Para as observações comportamentais, o invólucro era cortado e afastado lateralmente até permitir a visualização dos favos. Ao final das observações o invólucro era recolocado no lugar original e, após isso, as próprias vespas completavam sua fixação no local original.

A identificação dos indivíduos foi feita marcando-se os sujeitos com tinta atóxica no tórax segundo um código de cores. Para isso eles eram coletados na entrada do ninho com pinça ou aspirador, introduzidos em tubos de ensaio e colocados em gelo até o torpor. Após marcação eles eram liberados ou na entrada do ninho, ou sobre o invólucro ou favos. Algumas escoteiras foram marcadas enquanto executavam o comportamento de arrastar o abdômen num substrato ("dragging", componente do caminho químico), ou quando estavam agrupadas no local selecionado para a construção do novo ninho. As rainhas foram marcadas após a abertura ou remoção do invólucro e favos.

A idade relativa dos indivíduos foi determinada de acordo com a pigmentação do apódema transverso dos esternitos gastrais. Como essa pigmentação aumenta com a idade, 4 classes de idade relativa foram definidas: 1, sem pigmento; 2, marrom claro; 3, marrom escuro; 4, preto. (Richards, 1971; 
West-Eberhard, 1973; Forsyth; 1981; Mateus et al., 2004). O desenvolvimento ovariano e a inseminação dos indivíduos (cf. Mateus et al., 2004) foram avaliados após dissecação e usando um estereomicroscópio binocular Wild M5. Os registros comportamentais foram feitos com filmadora Panasonic M9000 fixa em tripé com lentes "close-up" +2 e +3 . Fotos, slides e observação direta foram também amplamente empregados. Visando evitar demasiadas interferências, as sessões de registros em vídeo e observações diretas foram feitas em dias e períodos espaçados, com duração mínima de uma hora. Para a obtenção do repertório comportamental das rainhas, operárias e intermediárias, seguiram-se os procedimentos de amostragem esporádica e acompanhamento individual (Fagen \& Goldman, 1977). As freqüências dos atos comportamentais envolvendo as rainhas e as intermediárias foram analisadas e comparadas. $\mathrm{O}$ teste $t$ (dois grupos) ou One Way ANOVA (mais que dois grupos) foram empregados para se avaliar diferenças entre as freqüências dos atos comportamentais ligados à postura e interações competitivas entre as rainhas e entre as rainhas e intermediárias nas diferentes fases do ciclo colonial. Em caso de rejeição da distribuição normal, o teste One Way ANOVA on Ranks (Kruskal Wallis One Way) foi utilizado. As análises dos dados foram realizadas no SigmaStat 3.1 e STATISTICA 6.0.

As colônias estudadas apresentaram as mesmas características de arquitetura de ninho e de ciclo colonial, como descrito por Mateus et al., (2004). A seguir apresentaremos alguns detalhes sobre as colônias estudadas:

- colônia C1 estava localizada em uma árvore isolada em área de pastagem a 4,5 metros de altura, próxima de habitação humana com pomar, continha 10 favos com imaturos e pupas (fase de produção de operárias).

- colônia C2 estava localizada em um pilar de tijolos a 2,5 metros de altura, continha 7 favos com imaturos e pupas (fase de produção de machos).

- colônia C3 estava localizada em uma árvore isolada em área de pastagem a 5 metros de altura, continha 10 favos com imaturos e pupas (fase de produção de machos). 
- colônia C4 estava localizada em uma coluna de madeira de uma varanda com cobertura a 1,75 metros de altura, continha 11 favos com imaturos e pupas (fase de produção de machos).

- colônia C5 estava localizada em um galho de uma árvore em área de pastagem a 3 metros de altura, continha 9 favos com imaturos e pupas (fase de produção de operárias).

- colônia C6 estava localizada em galho de árvore em área de pastagem a 4,5 metros de altura, continha 9 favos com imaturos e pupas (fase de produção de machos).

A seguir, definem-se alguns termos utilizados neste trabalho:

- Ninho - a estrutura física que dá abrigo aos indivíduos componentes da colônia.

- Colônia - a unidade social que ocupa o ninho, constituindo-se de imaturos e adultos.

- Duração do ninho - em valores absolutos é o tempo decorrido entre a fundação e o término das atividades da colônia; em termos relativos é o período entre o início das observações e o abandono do ninho.

- Enxame - ("reproductive swarm", cf. Richards \& Richards, 1951) divisão reprodutiva da colônia que se encontra em fase de produção de novos indivíduos sexuados.

- Migração forçada - ("absconding", "evacuating swarm”, cf. Richards \& Richards, 1951) enxameio induzido por mecanismos adversos, como predação e outros fatos acidentais. Neste trabalho, refere-se ao mecanismo que se segue à remoção de partes da estrutura do ninho e, como tal, representa uma maneira de se abordar embora forçadamente, os mecanismos envolvidos na migração colonial.

- Deslocamento ou migração da população - precedida pelo préenxameio e início do estabelecimento. É o deslocamento da população usando o caminho químico previamente estabelecido pelas escoteiras do local do ninho original (LNO) até o local do novo ninho (LNN). 
- Rainhas - fêmeas com síndrome comportamental diferente de operárias, não executam nenhum tipo de trabalho na colônia exceto posturas, têm ovários muito desenvolvidos e são inseminadas.

- Operária - fêmea que desenvolve diferentes tarefas na colônia, de acordo com a necessidade.

- Intermediárias - fêmeas apresentando desenvolvimento ovariano consistente e não estão inseminadas (Richards \& Richards, 1951).

- Escoteira - operária que durante o pré-enxameio deixa o ninho original em busca de um novo local para construir o novo ninho, faz caminho químico e marca o novo local do ninho depositando veneno (este estudo).

- Ovo/óvulo - estes termos serão usados indistintamente, sem levar em conta a usual conotação embriológica - funcional.

- Ciclo colonial - período de desenvolvimento da colônia que compreende o final de um episódio reprodutivo colonial até o final de outro consecutivo. Colônias com ciclo curto são aquelas que alcançam o ciclo reprodutivo rapidamente. Quando varias gerações são produzidas anteriormente à produção de sexuados, temos um ciclo longo.

Neste estudo utilizamos as seguintes denominações para as fases das colônias estudadas:

- Fase de produção de operárias - foi considerado neste trabalho uma fase com várias rainhas na colônia realizando posturas (colônia C5).

- Pré-enxameio - período de duração entre a destruição do ninho até a migração da população, as escoteiras iniciam a busca de um novo local para a construção do novo ninho (este trabalho).

- Estabelecimento da colônia ou pré-emergência - desde a chegada da população ao novo local do ninho e início da construção dos favos e invólucro (este trabalho).

- Pós-estabelecimento - ninho com invólucro completo, presença de imaturos nos favos (este trabalho). 
A partir das análises dos registros em vídeo e das observações diretas criou-se um catálogo de atos comportamentais para as rainhas e intermediárias das colônias estudadas.

A seguir faremos a descrição dos principais atos comportamentais realizados pelas rainhas durante as diferentes fases das colônias estudadas.

\section{Comportamentos ligados à postura.}

1. Inspeção de célula (IC): durante o comportamento de patrulha nos favos, a rainha insere a cabeça no interior de células vazias ou não, pode preceder a postura.

2. Postura (PO): invariavelmente ocorre após a inspeção de uma célula, a rainha introduz o abdômen na célula, fica com as asas ligeiramente abertas permanecendo assim até a eliminação do ovo.

3. Fixar o ovo (FXO): ocorre sempre após a postura, a rainha vira-se e por alguns segundos toca o ovo com o aparelho bucal. Também foi observado ocorrer em relação a ovos alheios.

\section{Comportamentos individuais realizados pelas rainhas}

4. Parada (PR): a rainha fica parada no substrato ou favo, às vezes, com as asas semi abertas e movimentando as antenas.

5. Voar (VR): rainha deixa o agrupamento em vôo, ocorre especialmente durante o pré-enxameio.

6. Limpeza, "grooming" (AL): ocorre principalmente, quando as rainhas estão próximas. Nesses casos, elas esfregam os esternitos gastrais com o último par de pernas e passam essas mesmas pernas nas asas, várias vezes.

7. Macerar presa (MA): rainha divide alimento sólido geralmente com operárias, não divide com outro indivíduo ou alimenta larvas.

8. Tocar polpa úmida (TPO): rainha toca com as antenas e mandíbulas o material vegetal que está sendo adicionado pelas construtoras.

Interações com adultos 
9. Curvar abdômen (CR): parada ou em movimento a rainha curva o abdômen em direção à outra rainha ou operária próxima, ou recebe este comportamento de outra rainha. Sugere-se que esses atos façam parte dos mecanismos de dominância.

10. Receber de outra rainha o curvar abdômen (RCR).

11. Curvar abdômen para operárias (CRO).

12. Contato corporal entre rainhas (CCR): rainha se aproxima e encosta o corpo em outra rainha, forçando-o lateralmente e permanecendo assim por alguns instantes. Ocorre entre duas, ou até 5 rainhas.

13. Rainhas agrupadas sem contato corporal (RAG): envolve de 2 até 6 rainhas que, permanecendo próximas, geralmente, se envolve em auto-limpeza.

14. Locomoção (LC): enquanto se desloca pelo substrato a rainha faz contato bucal e pode receber alimento liquido e sólido das operárias.

15. Trofaláxis (TR): ocorre entre rainhas, intermediárias e operárias. A rainha introduz a glossa entre as mandíbulas abertas de outra rainha, intermediária ou operária que expõe uma gota. A rainha solicitante geralmente prende a doadora com o primeiro par de pernas.

16. Trofaláxis com rainha (TR-R).

17. Rainha é agredida por operárias (AGR): operária avança para a rainha com mandíbulas abertas tentando mordiscá-la quando esta tenta contato bucal, ou mesmo enquanto ela se locomove pelos favos.

\section{Interações competitivas}

18. Retira rainha da célula (RR): rainha empurra com a cabeça ou mordisca outra rainha que está com o abdômen inserido numa célula.

19. Rainha que foi empurrada da célula (RT): 
20. Retira rainha da célula enquanto fixa ovo (RRFX): rainha empurra com a cabeça ou mordisca outra rainha que está fixando seu ovo.

21. Rainha que foi empurrada da célula enquanto fixava ovo (RTFX):

22. Oofagia (Oof): rainha toca o ovo com as antenas por alguns segundos e em seguida o ingere.

23. Tentativa de postura (TP): rainha apenas insere o abdômen na célula sem botar, é impedida por outra rainha ou intermediária.

\section{Interação com imaturos}

24. Contato bucal com larva (CBL): durante as incursões pelos favos a rainha toca as larvas com as antenas. Após abertura de mandíbulas pode ocorrer a transferência de fluidos.

Descrição dos principais atos comportamentais realizados pelas intermediárias durante o enxameio nas diferentes fases das colônias estudadas.

\section{Construção do ninho}

25. Construir invólucro (CI): intermediária adiciona polpa macerada na borda do invólucro iniciada por outro indivíduo ou por ela mesma.

26. Macerar polpa (MP): intermediária trabalha a polpa com as mandíbulas e primeiro par de pernas, adiciona saliva e utiliza esse material na construção de células ou envelope.

27. Dividir polpa (DP): intermediária divide massa de polpa com outra construtora, que poderá dividí-la novamente.

\section{Manutenção da colônia}

28. Ventilação (FAN): intermediária vibra as asas o que contribui para a aeração do ninho.

29. Relocar polpa (REL): com as mandíbulas a intermediária remove uma porção de polpa e a transfere para outro local.

\section{Cuidado com a prole}


30. Macerar presa (MA): intermediária macera presa trazida por forrageadora, ou recebe de outra operária.

31. Alimentar larvas com presa (ALP): intermediária alimenta larva com presa macerada.

\section{Interações com adultos}

32. Receber da rainha curvar abdômen (IRC).

33. Trofaláxis (TR): intermediária requisita fluido, ou este é dela requisitado por outro indivíduo. Após antenação uma das vespas (doadora) abre as mandíbulas enquanto a outra (solicitante) suga o fluido.

34. Sendo limpa (SL): intermediária permanece imóvel recebendo limpeza de uma ou mais operárias.

35. Limpeza de operária (LO): intermediária limpa o corpo de outra operária.

\section{Interação com imaturos}

36. Contato bucal com larva (CBL): intermediária faz contato bucal com larva após tocá-la com as antenas. Ocorre troca de fluidos.

\section{Comportamentos individuais realizados pelas intermediárias}

37. Auto-limpeza (AL): a intermediária esfrega as pernas posteriores no abdômen, asas e uma perna na outra; com as pernas anteriores limpam também o tórax, cabeça, antenas e mandíbulas e, por fim, as lambe. Não necessariamente ocorrem todos esses passos nem sempre ocorrem integralmente ou, na mesma ordem.

38. Inspeção de célula (IC): intermediária inspeciona o interior da célula que contém ovos ou larvas com as antenas.

39. Postura (PO): ocorre após a inspeção de uma célula, a intermediária introduz o abdômen na célula, fica com as asas ligeiramente abertas permanecendo assim até a eliminação do ovo.

40. Fixar o ovo (FXO): ocorre sempre após a postura, a intermediária vira-se e por alguns segundos toca o ovo com o aparelho bucal. Ocorre também em relação a ovos alheios.

\section{Interações competitivas}


41. Retira rainha ou intermediária da célula (RRI): intermediária empurra com a cabeça ou mordisca outra intermediária ou rainha que esteja com o abdômen inserido na célula enquanto tentava realizar sua própria postura.

42. Intermediária retirada da célula (IRT):

43. Retira intermediária ou rainha enquanto fixa ovo (RFX): Intermediária empurra com a cabeça ou mordisca outra intermediária ou rainha que esteja fixando ovo.

44. Intermediária retirada enquanto fixava ovo (IFX):

45. Oofagia (Oof): Intermediária toca o ovo com as antenas por alguns segundos e em seguida o ingere.

46. Tentativa de postura (TP): intermediária apenas insere o abdômen na célula sem botar, é impedida por outra intermediária ou rainha.

Atos comportamentais não quantificados realizados por intermediárias enquanto escoteiras durante o enxameio.

47. Arrastar o abdômen num substrato, "dragging behavior" - comportamento executado por intermediárias agindo como escoteiras durante o préenxameio. A finalidade é estabelecer um caminho químico (vários substratos) entre o ninho original (LNO) e o novo ninho (LNN). Idem para marcação do local do LNN.

48. Deposição de veneno no local do novo ninho - embora basicamente um comportamento defensivo serve, também, para marcar o local do novo ninho e, provavelmente, o ponto final do enxameio.

49. Recrutamento pós-migração - Após a migração da população para o LNN as intermediárias enquanto escoteiras retornam ao ninho original usando o caminho químico. No LNO elas pousam no substrato, fazem contatos bucais e "dragging". 


\section{C - RESULTADOS E DISCUSSÃO}

\section{C.1 - Análise cronológica do processo de enxameio forçado de $P$. fraternus obtido após remoção total das estruturas do ninho (exceto da colônia $\mathrm{C} 5$ ).}

\section{C.1.1 - Colônia C1:}

25/02/01: o invólucro do ninho foi parcialmente removido (Fig. 3 A). As vespas atacaram com ferroadas e aspergiram veneno "venom spraying" na máscara do experimentador. Logo após a remoção do invólucro grande parte da população se dispersou, pousando em folhas da mesma árvore ou em folhas de árvores próximas, sozinhas ou em pequenos grupos. Os indivíduos que ficaram no ninho removeram imaturos (larvas e pré-pupas) das células. No início os imaturos eram macerados por uma ou mais vespas, depois eles eram retirados das células e jogados para fora, em vôo ou da borda dos favos. Vários indivíduos vibraram as asas "buzz running" no substrato ou sobre os favos. Até o final do dia, esses comportamentos não se alteraram. Os indivíduos que se dispersaram, retornaram gradualmente ao ninho.

26/02/01: o restante do invólucro e os favos foram removidos (9h 00min) restando, portanto, apenas a cobertura do substrato na área delimitada pelo invólucro. Novamente, a população se dispersou. Mesmo com a remoção total do invólucro e dos favos os indivíduos permaneceram no local do ninho, muitos voaram pousando próximo do ninho retornando gradualmente. Não houve formação de grupos de indivíduos nas áreas próximas do ninho, mas apenas uma grande dispersão da população, cujos indivíduos isoladamente pousavam nas folhas. Foram identificadas e marcadas com tinta no tórax, sem serem removidas do ninho, 11 rainhas. Elas ficavam preferencialmente no centro do grupo, próximas umas das outras ou até mesmo encostadas umas nas outras, 
curvavam o abdômen para operárias e rainhas. Além disso, elas tentavam contato bucal com as operárias que na maioria das vezes fugiam.

10h 45min: grande agitação da população causada por duas vespas que arrastaram o abdômen "dragging" no ápice do agrupamento e voaram. As vespas voavam em várias direções e a diferentes distâncias do ninho original (10, 20, 30 e 40 metros). Esses vôos eram sempre em volta de árvores. De tempos em tempos, elas pousavam em folhas periféricas, tocavam com as antenas a superfície dessas folhas, voavam e pousavam em outra folha e repetiam o mesmo comportamento. $\mathrm{O}$ "buzz-running" foi realizado com mais freqüência por operárias, que se locomoviam pelo agrupamento o que contribuía para desencadear o mesmo comportamento noutros membros da colônia. As vespas que retornavam do campo locomoviam-se agitadas entre os indivíduos fazendo muitos contatos bucais o que causava agitação nos demais membros da colônia no local do ninho original. O comportamento dos indivíduos permaneceu o mesmo, exceto pelo aumento gradativo no número de vespas saindo do ninho e retornando do campo, muitos contatos bucais, "dragging" no substrato do ninho original.

15h 00min: um grupo de 12 escoteiras foi encontrado em uma coluna de madeira de uma varanda a 28 metros de distância do ninho original (Fig. 3 B). É importante mencionar que essa localização só foi possível seguindo-se a trilha formada pelas escoteiras fazendo "dragging" nas folhas periféricas de árvores e arbustos. No LNN (local do ninho novo) as escoteiras voavam em volta do agregado, pousavam, tocavam o substrato com as antenas e aparelho bucal, faziam "dragging" pressionando os esternitos gastrais no substrato com leves movimentos laterais, voavam, pousavam no substrato repetindo os mesmos comportamentos, ou retornavam ao LNO (local do ninho original) percorrendo o caminho químico antes estabelecido. Dez indivíduos fazendo estes comportamentos no LNN foram marcados com tinta no tórax. Posteriormente essas escoteiras foram observadas no LNO executando agitados contatos bucais e retornando ao LNN. 
No ninho original a situação permaneceu a mesma até o final do dia. Grande parte da população lá permaneceu formando pequenos grupos. As escoteiras continuaram a visitar o LNN usando o caminho químico feito nas folhas mais externas das árvores. A alta freqüência de "dragging" nas mesmas folhas sugere o comportamento de reforçar o caminho químico previamente estabelecido.

27/02/01: muitos indivíduos voavam em volta do LNO, pousavam e faziam vários contatos bucais. $8 \mathrm{~h} 50 \mathrm{~min}$ : várias vespas, inclusive marcadas, visitavam o LNN usando o caminho químico feito no dia anterior. O comportamento das escoteiras não se alterou, mas suas atividades nitidamente aumentaram de intensidade e agitação. Retornando ao LNO elas mantinham os mesmos comportamentos agitados. Muitos "dragging" foram feitos antes que elas deixassem o ninho. 11h 00min: seis indivíduos foram marcados no tórax enquanto percorriam o caminho químico. Posteriormente, esses indivíduos foram observados fazendo "dragging" no LNO, e depositando veneno no LNN. 11h 30min: no LNN, 22 escoteiras faziam "dragging" e depositavam veneno. 12h 09min: dos registros em vídeo estimou-se que LNO havia 287 indivíduos. Estimuladas pelas escoteiras que retornavam do LNN a população se mantinha muito agitada. Muitos indivíduos voavam em círculos, pousavam, locomoviamse rapidamente pelo agrupamento, faziam rápidos contatos bucais e retornavam para o caminho químico.

Com o aumento do número de vespas no LNN houve, também significativo aumento na agitação das vespas que faziam um "dragging" mais vigoroso, isto é, percorrendo agitadas a superfície elas moviam rapidamente o abdômen para os lados, em seguida, parando bruscamente, elas curvavam o terminal abdominal até tocar o substrato. Seguia-se uma nítida contração do abdômen com deposição de veneno. Esses comportamentos foram desenvolvidos repetidamente e sempre sob muito agitação. A análise de alguns registros em vídeo mostrou que, nessas ocasiões, os dois últimos segmentos abdominais se abriam permitido visualizar a exposição parcial do ferrão. 
12h 30min: o número de indivíduos na trilha aumentou consideravelmente. No LNN havia aproximadamente 260 indivíduos. As escoteiras que pousavam realizavam "dragging" e depositavam veneno, com muito mais agitação do que anteriormente observado.

13h 05min: grande número de indivíduos voava em volta do LNN. Observavase muita agitação entre os indivíduos que estavam no substrato. O número de indivíduos no caminho químico aumentou, assim como, aumentou o número de indivíduos voando próximos ao LNN. 13h 15min: no LNO o número de indivíduos diminuiu em torno de $50 \%$, grande parte da população voava ao seu redor e, também na trilha deixada pelas escoteiras. No LNN já havia grande número de indivíduos voando em volta e as escoteiras continuavam a fazer "dragging" no substrato. 13h 40min: no LNO um indivíduo removeu material vegetal e se direcionou para o LNN. 13h 57min: foi estimado em vídeo que 252 indivíduos estavam no LNN. Muitos voavam ao seu redor e vários outros retornavam ao LNO usando o caminho químico. Pouco depois o LNO estava vazio. A migração da população, desde o momento da revoada no LNO até a população atingir o LNN, durou cerca de 30 minutos. Nesse período, houve grande movimentação de vespas no caminho químico. Ao atingir o LNN, os indivíduos, repetidamente, voavam em volta do substrato, pousavam, tocavam o substrato com as antenas e faziam muitos contatos bucais.

As construções das bases de três pedúnculos e dos primórdios do invólucro foram iniciadas imediatamente após a chegada da população ao LNN, pois como se relatou, algumas escoteiras já estavam removendo polpa vegetal do LNO antes mesmo da migração total da população. Logo após o estabelecimento da população no LNN, a atividade das forrageadoras que coletavam polpa vegetal no LNO, aumentou consideravelmente. Aos poucos essa atividade tornou-se independente do caminho químico e, três dias após a migração, as forrageadoras ainda foram vistas voando do LNO para o LNN diretamente. Os favos foram construídos no centro da área onde as escoteiras fizeram a maior parte da marcação com veneno. Nos primeiros momentos a população espalhou-se por $50 \mathrm{~cm}$ abaixo do local marcado, formando uma linha de defesa contra possíveis predadores e formigas. Logo que iniciaram a 
construção de favos e invólucro, algumas escoteiras marcadas no caminho químico e no LNN, foram observadas trazendo água e polpa e, inclusive, distribuindo esses materiais entre as construtoras. A duração do pré-enxameio na colônia $\mathrm{C} 1$ foi de 50 horas, o novo ninho foi construído 28 metros do ninho original (Tabela 2).

\section{C.1.2 - Colônia C2:}

22/03/01: 9h 00min: o invólucro do ninho foi totalmente removido. Os adultos reagiram agressivamente com ferroadas e aspergindo veneno. As vespas que ficaram nos favos retiraram larvas das células. 9h 30min: os favos foram removidos, a população se dispersou pousando em folhas de árvores próximas. Não houve a formação de grupos. Poucos indivíduos ficaram no local do ninho. A população retornou ao ninho gradativamente. Nove rainhas foram marcadas no tórax sem serem removidas do substrato. Elas ficavam preferencialmente no centro do grupo, raramente próximas umas das outras e curvavam o abdômen para operárias próximas ou mesmo para outras rainhas. Além disso, elas tentavam contato bucal com as operárias que na maioria das vezes fugiam.

Durante o pré-enxameio algumas forrageadoras traziam água que era imediatamente distribuída. 14h 02min: uma forrageadora pousou com uma presa. Várias operárias participaram da divisão do alimento. 15h 45min: uma rainha dividiu com uma operária um pedaço de presa que a operária macerava. 17h 00min: a população estava calma. Muitos indivíduos imóveis compunham pequenos agrupamentos no substrato.

23/03/01: 8h 00min: formando cinco grupos, operárias e rainhas estavam imóveis no substrato. 10h 00min: os indivíduos começaram a movimentar-se pelo substrato. Ocorreram contatos bucais e alguns voavam em volta do ninho. Com o aumento da temperatura as operárias começaram a forragear água e a distribuí-la. 13h 00min: foram marcados no tórax alguns indivíduos que retornavam ao ninho. Mesmo com a destruição das principais estruturas duas forrageadoras trouxeram presas. A partilha causou agitação o que atraiu algumas rainhas. 14h 00min: grande número de indivíduos pousando e 
deixando o ninho. Os vôos tomavam rumos diversos. Ao pousar em folhas eles tocavam a superfície com as antenas e retornavam ao ninho. $16 \mathrm{~h}$ 27min: uma escoteira fez "dragging" no substrato do LNO. Logo a seguir ela se dirigiu para as folhas de uma árvore próxima. 16h 45min: uma escoteira fazia "dragging" numa parede a 10 metros do LNO. O comportamento das rainhas não se alterou. Elas ficavam preferencialmente paradas curvando o abdômen sempre que outro indivíduo aproximava. Ao se locomoverem, faziam solicitação de alimento para as operárias que, na maioria das vezes, fugiam.

24/03/01: 8h 39min: conforme já mencionado, havia vespas voando em várias direções e a diferentes distâncias do ninho original. Os indivíduos que retornavam sempre faziam muitos contatos bucais. Uma escoteira marcada no dia anterior fez "dragging" no ninho original e voou. Vários indivíduos foram atraídos até o local onde o "dragging" ocorreu. Eles tocaram o local com as antenas e, por alguns instantes, ficaram agitados. 12h 30min: aumentou o número de indivíduos em vôo. Foram observadas escoteiras voando em várias direções, pousando e fazendo "dragging" em tronco de árvores e folhas. Quando retornavam ao ninho elas faziam muitos contatos bucais, andavam agitadas e saiam em vôo.

25/03/01: 8h 40min: uma escoteira marcada retirava polpa vegetal do ninho. Entre $9 \mathrm{~h} 00 \mathrm{~min}$ até $10 \mathrm{~h} 00 \mathrm{~min}$ houve grande agitação na parte central do agrupamento no LNO. As escoteiras marcadas que pousavam, andavam rápido, fazia "dragging" e muitos contatos bucais o que causava grande agitação entre as vespas. Observando o rumo do vôo dessas escoteiras marcadas e utilização do caminho químico foi possível localizar um agrupamento com 12 vespas em um galho de jabuticabeira a 30 metros de distância do ninho original. No LNN as escoteiras voavam em volta do galho, pousavam e tocavam a superfície com as antenas e aparelho bucal, faziam "dragging", direcionavam a extremidade distal do abdômen para o substrato e depositavam veneno. As vezes era possível observá-las tocando o substrato com a parte distal dos tergitos gastrais. Essas seqüências eram freqüentemente repetidas (Fig. 3 C e D). 
No LNO havia muita agitação, muitos contatos bucais e muitos indivíduos retornando ao ninho vindo de várias direções, apesar de já existir um agrupamento (LNN) e uma trilha já estabelecida pelas escoteiras. O número de indivíduos na trilha que conduzia ao LNN na jabuticabeira aumentou gradativamente. As escoteiras que retornavam ao LNO faziam muitos contatos bucais andando rapidamente entre a população e, antes de voar, faziam "dragging".

11h 07min: havia 24 escoteiras no novo local do ninho, fazendo "dragging" e depositando veneno no substrato. A comunicação entre LNO e LNN já estava estabelecida. 11h 26min: no LNN se observou um indivíduo com uma pequena massa de polpa vegetal nas mandíbulas. 11h 32min: aproximadamente 73 indivíduos estavam no LNN e havia dezenas voando ao seu redor. Indivíduos que pousavam faziam uma espécie de reconhecimento tocando o substrato com as antenas. 11h 35min: no LNO havia 165 indivíduos no substrato. Além disso, dezenas estavam voando e percorrendo a trilha. Havia muita agitação. Boa parte dos indivíduos que retornava ao LNO fazia "dragging", contatos bucais e voavam na direção do caminho químico. Como o número de indivíduos fazendo “dragging" e depositando veneno no substrato do LNN era elevado, foi possível sentir forte cheiro de veneno no ar.

11h 37min: a primeira rainha chegou ao LNN. Ao pousar tocou o substrato com as antenas e passou a curvar o abdômen para as operárias que se apresentavam muito agitadas. 11h 40min: havia cerca de 100 indivíduos no substrato do LNN. Dezenas voavam nas vizinhanças, outros pousavam nas folhas como que procurando o caminho químico. 11h 54min: no LNO restou uma rainha e 8 operárias. Algumas escoteiras voavam ao redor, pousavam e faziam o recrutamento dos indivíduos restantes via contatos bucais e "dragging". 12h 00min: no LNN havia dezenas de indivíduos voando em volta da árvore, pousando nas folhas. Oito rainhas já haviam pousado no LNN. O número de indivíduos fazendo "dragging" no substrato diminuiu com a chegada em massa 
da população. 12h 06min: inicia-se a construção do primeiro pedúnculo. Algumas forrageadoras retornaram ao LNO para coletar fibra vegetal.

A migração da população ocorreu entre $11 \mathrm{~h}$ 30min e $11 \mathrm{~h} 55 \mathrm{~min}$. Estimuladas pelas escoteiras as vespas deixaram o LNO gradualmente e voavam em busca do caminho químico. Mesmo com a chegada da maior parte da população ao LNN, várias escoteiras continuaram a percorrer a trilha até o LNO o que, com certeza, contribui para aumentar a eficiência da migração. No final do dia, os indivíduos que não enxamearam foram coletados. Eram 6 machos jovens, e uma rainha que havia sido previamente marcada. A dissecação revelou que ela não era jovem (apódemas dos esternitos gastrais bem pigmentados). Seus ovários estavam bem desenvolvidos, com vários ovócitos maturos, e ela estava inseminada. A duração do pré-enxameio na colônia C2 foi de 74 horas e 50 minutos, o novo ninho foi construído 30 metros do ninho original (Tabela 2).

\section{C1.3 - Colônia C3:}

Antes da remoção das estruturas do ninho para estudo do processo de migração forçada, na parte externa do invólucro da colônia C3, a $25 \mathrm{~cm}$ acima da entrada do ninho foi construída uma pequena câmara, ela se fixava à lateral do invólucro e no substrato (Fig. 3 E). Não havia comunicação entre a câmara e o interior do ninho. Nela foram coletadas e fixadas 8 fêmeas. Após a dissecação verificou que entre elas havia 2 intermediárias de padrão 5 de desenvolvimento ovariano, 3 indivíduos de padrão 3, 2 indivíduos de padrão 2 e uma fêmea sem desenvolvimento ovariano. Os indivíduos não eram jovens (Mateus et al., 2004). O ninho estava em fase de produção de machos. Posteriormente foi verificada a presença de intermediárias. A presença de intermediárias coletadas no interior da câmara possivelmente é um indício de que estava ocorrendo conflito no interior do ninho. Durante o estabelecimento ocorreu a eliminação de rainhas da colônia. 
03/03/2003: 11h 30min: o invólucro e 10 favos do ninho original foram removidos. A reação das vespas ocorreu como já descrito nos casos anteriores. Não houve formação de agregados, apenas forte dispersão das vespas. A população voltou ao ninho gradativamente, sempre fazendo muitos contatos bucais, limpeza corporal. No período da tarde houve grande movimentação, as vespas voavam em volta do ninho e sobre as folhas de árvores próximas. No final da tarde elas se acalmaram e havia poucos indivíduos voando. Vários agrupamentos foram observados sobre o substrato. O comportamento de préenxameio não diferiu dos demais ninhos estudados. A colônia estava na fase de produção de machos, nos favos removidos foram encontradas poucas pupas, as larvas e ovos estavam nas células centrais e as células periféricas estavam vazias.

04/03/03: no período da tarde as vespas voavam em várias direções e a diferentes distâncias do ninho original. Foram observadas escoteiras voando sobre folhas de árvores distantes 50 metros do ninho original. Um grupo de escoteiras foi encontrado em uma coluna de varanda (LNN) distante 28 metros do LNO. Esses indivíduos pousavam no substrato, tocavam a superfície com as antenas e aparelho bucal e faziam "dragging", voavam, retornavam e repetiam os mesmos comportamentos. Nesse dia, houve pouca alteração numérica neste agrupamento. O comportamento das rainhas durante o pré-enxameio não diferiu do que foi observado nas colônias anteriores. Elas permaneciam agrupadas, curvando o abdômen e solicitando alimento das operárias.

05/03/03: 10h 34min: havia grande movimentação de vespas no LNO. No LNN foram observadas 8 escoteiras que no substrato faziam "dragging". As escoteiras que deixavam o LNN seguiam um caminho químico feito em folhas de árvores até o LNO. 11h 06min: no LNN foram marcadas com tinta no tórax 40 escoteiras. Os comportamentos não diferiram do que fora observado anteriormente, mas tanto o "dragging", como a deposição de veneno no substrato desenvolvia-se sob maior agitação. No LNN, mesmo antes da migração final da população algumas escoteiras já dividiam polpa vegetal e, inclusive, iniciaram a construção de dois pedúnculos simultaneamente. A migração final iniciou-se com a revoada de dezenas de indivíduos em volta do LNO estimuladas pelas escoteiras que 
faziam "dragging" no substrato e voavam para o caminho químico. 11h 23min: dezenas de vespas voavam em volta do LNN, foram contados 108 indivíduos no substrato, enquanto que no LNO restavam muitas vespas. Durante a migração a população utilizou o caminho químico ligando os dois ninhos e que fora feito pelas escoteiras nas folhas de árvores e arbusto. 11h 46min: no LNN, entre outras obreiras, duas escoteiras construíam dois pedúnculos. As rainhas ficaram concentradas acima dessa área de construção. Algumas escoteiras foram observadas fazendo "dragging" e depositando veneno no substrato após a chegada da população. Após a migração, as vespas forrageadoras de polpa retornavam ao LNO para coletar material de construção onde restaram apenas alguns machos. A duração do pré-enxameio na colônia C3 foi de 48 horas, o novo ninho foi construído 28 metros do ninho original (Tabela 2).

\section{C.1.4 - Colônia C4:}

03/03/2003: o invólucro e 11 favos foram removidos as $15 \mathrm{~h} 20 \mathrm{~min}$. Seguiram-se os mesmos comportamentos já descritos para as colônias anteriores. No ninho foram observados machos. No período da tarde houve grande movimentação de vespas voando em volta do ninho e sobre as folhas de árvores próximas. No final da tarde havia pouca movimentação da população, vários agrupamentos foram observados sobre o substrato. $\mathrm{O}$ comportamento de pré-enxameio não diferiu dos demais ninhos estudados. Nos favos havia poucas pupas, as larvas e ovos estavam nas células centrais, e as células periféricas estavam vazias.

04/03/03: muitas escoteiras voando em busca de um novo local para o ninho, no substrato do LNO ocorriam contatos bucais e "dragging". No período da tarde algumas escoteiras que retornavam ao ninho foram capturadas e marcadas. A movimentação de escoteiras era intensa. Aparentemente não tinham ainda um local definido para construção do ninho, pois chegavam de todas as direções. Esta situação permaneceu a mesma até o final do dia.

05/03/03: intensa movimentação de escoteiras saindo e retornando ao ninho, foram observados vários indivíduos fazendo "dragging" no LNO. Seguindo a 
direção de vôo de maior fluxo de escoteiras, foi encontrado um agrupamento distante 22 metros do ninho original. Ele se localizava numa parede. Onze escoteiras, algumas das quais foram marcadas no dia anterior estavam presentes. Elas tocavam a superfície com as antenas, faziam "dragging" e em seguida depositavam veneno no substrato. O número de escoteiras neste agrupamento variava, algumas saiam e voavam até o LNO. Apesar de já haver um agrupamento de escoteiras, muitas vespas retornavam e deixavam o ninho voando em várias direções. 11h 20min: a movimentação de escoteiras retornando ao ninho original ficou mais intensa. Antes de voar elas faziam muitos contatos bucais, andavam rapidamente entre a população e faziam “dragging". A soma desses comportamentos acarretava agitação entre os indivíduos.

A população migrou entre $12 \mathrm{~h} 15 \mathrm{~min}$ e $13 \mathrm{~h}$ 35min. Não foi possível acompanhar o momento exato da migração. No LNO restaram algumas operárias e alguns machos. As escoteiras que retornaram ao ninho faziam contatos bucais com estes indivíduos e, as vezes, "dragging" no substrato estimulando-os a migrar. Os machos não acompanharam o enxame. Após a migração, vários indivíduos retornaram ao LNO, inclusive, várias escoteiras marcadas, para coletar polpa vegetal e utilizá-la na construção do novo ninho. $\mathrm{O}$ LNN foi encontrado no dia seguinte, distante 75 metros do ninho original e a 12 metros de altura. O invólucro já estava delimitado e havia 4 favos pequenos. A duração do pré-enxameio na colônia C4 foi de 49 horas, o novo ninho foi construído 75 metros do ninho original (Tabela 2).

\section{C.1.5 - Colônia C5, enxameio natural:}

A população estava identificada com código de cores, estudos sobre comportamento de rainhas e operárias estavam sendo realizados desde 15/04/03, o invólucro era afastado periodicamente. Em 14/06/03 a população apresentou comportamentos de pré-enxameio. Parte da população estava inativa no interior do ninho, algumas vespas faziam vôos circulares em volta do 
ninho e voavam para as folhas da árvore onde o ninho esta fixado ou para folhas de árvores próximas. Nessas folhas elas pousavam, tocavam a superfície com as antenas e voltavam para o ninho. O invólucro foi parcialmente removido para observações intraninho e não foi reconstruído como observado anteriormente.

Não se verificou entrada de alimento ou material de construção e, devido à remoção de imaturos das células, não havia pupas nos favos e muitas células estavam vazias. Duas operárias marcadas (códigos 21 e 99) retornaram ao ninho muito agitadas, fazendo muitos contatos bucais. As rainhas permaneceram paradas no interior do ninho, próximas umas das outras, com asas semi abertas e curvando o abdômen para operárias. Havia machos no ninho.

15/06/03: 11h 00min: grande movimentação de saídas e retornos ao ninho. A operária (código 90) pousou na entrada do ninho, fez vários contatos bucais, e antes de sair em vôo fez "dragging” no substrato.

15h 45min: o número de vespas deixando o ninho e procurando o caminho químico nas folhas aumentou. Isso foi causado pelo aumento do número de escoteiras fazendo "dragging" na entrada do ninho antes de voar. Havia dezenas de escoteiras voando para uma mesma direção (noroeste), mas não foi encontrado agrupamento de vespas. Muitas delas partiam e chegavam de várias direções, sempre fazendo os mesmos comportamentos. 16h 30min: o número de vespas voando nas proximidades do ninho, bem como, as saídas e retornos diminuíram rapidamente, até cessar.

16/06/03: 9h 10min: havia pouca atividade externa. A escoteira (código 10) foi observada fazendo "dragging" nas folhas da árvore onde estava localizado o ninho. Os comportamentos característicos de pré-enxameio continuaram, ou seja, muito contato bucal entre as escoteiras e os indivíduos no ninho, as escoteiras sempre fazendo "dragging" nas folhas ao longo do caminho químico. O número de indivíduos no campo aumentou gradativamente com o aumento da temperatura, algumas operárias ficavam sobre o invólucro próximo da entrada e interagiam com todas as vespas que retornavam ao ninho. A atividade de pré-enxameio aumentou no período da tarde, dezenas de indivíduos 
percorriam o caminho químico (direção noroeste) feito no dia anterior nas folhas das árvores e arbustos. Com o intenso fluxo de entradas e saídas, e o estímulo das escoteiras fazendo "dragging", as 1500 horas houve grande revoada de vespas em volta do ninho o que marcou o início da migração. Havia grande número de vespas percorrendo o caminho químico até o LNN num arbusto a 30 metros do LNO. Neste caso, o agrupamento de escoteiras que marca o LNN não pode ser encontrado antes da migração. 15h 25min: no LNO restavam algumas vespas, alguns indivíduos voavam em volta do ninho e seguiam a trilha. Após a migração foram observados cinco indivíduos (códigos 82, 51, 129, 156 e 116) retornando ao ninho original para coletar polpa vegetal. A coleta de polpa vegetal para a construção do novo ninho foi observada antes da migração da população. Esse material foi retirado do tubo de entrada e do interior do ninho. No LNN as operárias iniciaram simultaneamente a construção de dois pedúnculos. Após a migração, no LNO restaram duas rainhas marcadas, operárias sem marcas e alguns machos. Como as escoteiras continuaram com os comportamentos de recrutamento, no dia seguinte só restaram machos no LNO e todas as rainhas foram observadas no novo ninho. A duração do pré-enxameio na colônia C5 foi de 55 horas, o novo ninho foi construído 26 metros do ninho

original (Tabela 2). É interessante notar que a duração do pré-enxameio sem a destruição das estruturas do ninho na colônia C5 não diferiu muito das demais colônias estudadas.

\section{C.1.6 - Colônia C6:}

23/03/2004: no final da tarde o invólucro e 11 favos foram removidos. Seguiram-se os mesmos comportamentos já relatados nas colônias anteriores. 24/04/04: 10h, 30min: as vespas começaram a voar em volta do ninho e pousar nas folhas da árvore onde o ninho estava afixado. Durante todo o dia o padrão de comportamento de pré-enxameio desenvolveu-se como nos demais ninhos estudados, as escoteiras voavam em várias direções e distâncias do ninho original. Antes da migração, foram observadas duas vespas removendo polpa vegetal no LNO. Não foi possível traçar a direção seguida rumo ao LNN. No 
final do dia a população se distribuiu em pequenos agrupamentos sobre o substrato no LNO.

25/03/04: no período da manhã grande parte da população estava inativa no ninho, algumas escoteiras já faziam "dragging" em folhas ao redor do ninho, e quando retornavam, faziam "dragging" no substrato. Foi observada a entrada de água e de presa no ninho original, sendo ambas consumidas rapidamente pela população. O número de vespas voando em volta do ninho e sobre folhas aumentou rapidamente. Não havia uma trilha definida e as escoteiras voavam em várias direções. Com o estímulo das escoteiras, contatos bucais e "dragging" no substrato do LNO, a população foi se agitando e dezenas de vespas voavam em volta do ninho procurando um caminho químico. A população enxameou entre $12 \mathrm{~h}$ 53min e $14 \mathrm{~h} 15 \mathrm{~min}$. $\mathrm{O}$ momento da migração não foi observado. $14 \mathrm{~h}$ 15min: no LNO havia 4 vespas coletando polpa vegetal. No dia seguinte o LNN foi localizado, distante 33 metros do LNO. Estava num galho a 12 metros de altura. Exceto por um macho jovem coletado embaixo do ninho não restaram outros indivíduos no LNO. A duração do pré-enxameio na colônia C6 foi de 67 horas (Tabela 2). 


\section{C.2 - CONSIDERAÇÕES SOBRE O ENXAMEIO}

\section{C.2.1 - A comunicação durante o enxameio.}

Tivemos a oportunidade de constatar nesta espécie que mediante a migração forçada os indivíduos não estão preparados para um deslocamento imediato, precisam de um tempo variável para localizar um novo local para a construção de um novo ninho, isto inclui também fazer um caminho químico usando produtos glandulares. O caminho químico foi feito pelas escoteiras, indivíduos mais experientes em tarefas fora do ninho. É possível que não estejam preparadas fisiologicamente para a realização imediata de tal tarefa, possivelmente o número de escoteiras aumenta gradativamente assim que os indivíduos estejam preparados fisiologicamente, como foi observado neste trabalho.

O primeiro relato de glândulas externas no quinto esternito gastral em várias espécies de Epiponini foi feito por Richards (1971), e posteriormente estudado por Jeanne \& Post, 1982, Jeanne et al., 1983. Naumann (1975) foi o primeiro a descrever o comportamento de "gaster dragging", fazer um caminho químico esfregando o abdômen em um substrato que é seguido por uma população durante a migração, este comportamento foi observado em espécies dos gêneros Angiopolybia, Leipomeles, Polybia e Agelaia. Jeanne (1975b, 1981) confirmou experimentalmente as conclusões de Naumann (1975), as vespas seguiram uma trilha artificial feita com substâncias retiradas da glândula do quinto esternito gastral .

Em $P$. fraternus não foi encontrado evidência de glândulas externas nos esternitos gastrais (Jeanne et al., 1983; Downing, 1991; Smith et al., 2001; Smith et al., 2002), embora escoteiras de P. fraternus foram observadas por alguns autores fazendo o comportamento de "dragging" durante migração (Jeanne et al., 1983; Smith et al., 2002). De acordo com Jeanne et al., (1983) e Smith et al., (2002) os gêneros Angiopolybia, Agelaia, Parachartegus, Leipomeles, Chartergellus e 
Nectarinella não possuem glândulas externas no quinto esternito gastral, no entanto, operárias destes gêneros foram observadas fazendo "dragging" em diversos substratos (Smith et al., 2002). De acordo com Downing (1991) duas explicações são possíveis no caso destes gêneros que não foram encontradas evidências de glândulas externas: a primeira é que secreções oriundas de outras glândulas seriam aplicadas no abdômen, e este seria usado como um aplicador. A segunda explicação seria que glândulas externas nestas espécies, possivelmente pertencem à classe 1 (Noirot \& Quennedey, 1974), não tem dutos associados e sua atividade de produção e de secreção estaria intimamente associada somente com o período de enxameio. Segundo Jeanne et al., (1983) Parachartegus fraternus não tem glândulas externas nos últimos 4 esternitos, no entanto foram encontradas poucas glândulas localizadas no terço posterior no sexto esternito gastral, elas são notavelmente menores do que glândulas da classe III observadas em outras espécies, e ficam muito espalhadas para serem consideradas como glândulas.

De acordo com o comportamento realizado pelas escoteiras de $P$. fraternus quando faziam "dragging", os últimos segmentos gastrais abriam-se levemente e ficavam com aspecto de molhados na extremidade do sexto esternito, possivelmente liberavam produtos glandulares que eram espalhados com o abdômen, estes produtos poderiam ser oriundos da glândula de Dufour e também do reservatório de veneno. Também não podemos descartar a possibilidade da utilização de glândulas da classe III (Jeanne et al., 1983). Outra opção seria a utilização de glândulas da classe I, sua atividade de produção e de secreção estaria intimamente associada somente com o período de enxameio (Downing, 1991). Os resultados para as 6 colônias estudadas foram iguais, ou seja, a migração não foi imediata, assim podemos sugerir que os produtos glandulares para confecção do caminho químico não estavam prontos.

Apesar da ausência da glândula de Richards no quinto esternito gastral, durante os estudos das 6 colônias com migração forçada, as escoteiras foram eficientes na construção do caminho químico ligando o ninho original ao local do novo ninho, não diferente de algumas espécies estudadas (Naumann, 1975; 
Chadad, 1979; West-Eberhard, 1978b, 1982; Jeanne, 1979). As escoteiras de $P$. fraternus fizeram "dragging" principalmente em folhas de espécies vegetais para a confecção do caminho químico. Nossos resultados mostram que apesar da ausência de glândulas o caminho químico foi muito eficiente, direcionando a população enxameante ao LNN.

De acordo com nossos resultados, sugerimos que, possivelmente, em $P$. fraternus o veneno possa ser um dos componentes utilizados para fazer o caminho químico. Foi constatado neste estudo que dezenas de escoteiras marcam o LNN depositando veneno.

Em P. fraternus o comportamento de depositar veneno foi observado somente no local do novo ninho, no caminho químico feito pelas escoteiras foi observado apenas o comportamento de "dragging" em folhas de árvores e arbustos, possivelmente o veneno é utilizado de outra forma, é liberado através do ducto do ferrão e espalhado com o movimento de "dragging", porém pode haver outras substâncias químicas envolvidas nesta sinalização.

Algumas das espécies de vespas do gênero Parachartegus tem a capacidade de aspergir veneno "venom spraying" (Jeanne, 1995, WestEberhard, 1982), pois tem músculos especiais no reservatório de veneno (Maschwitz e Kloft, 1971), então sugerimos que para fazer o caminho químico elas também possam utilizar veneno, embora não tenha sido observada nenhuma escoteira depositando veneno no substrato enquanto faziam o caminho químico. Estudos com espécies de Ropalidine da África, Polybioides tabidus que não têm glândulas externas, sugerem que os produtos da glândula de Dufour são utilizados para fazer o caminho químico durante o enxameio (Francescato et al., 1993, 1994), e Polybioides raphigastra, provavelmente, usa a glândula de veneno (Smith et al., 2002) para o mesmo propósito.

\section{C.2.2 - Formas de deslocamento das populações durante a migração.}

De acordo com West-Eberhard (1982), ocorrem dois tipos distintos de migração nos Epiponini. A migração difusa ("diffuse swarms") observado em 
algumas espécies de Agelaia (= Stelopolybia), onde as vespas espalham-se por uma área superior a 100 metros de comprimento por 20-50 metros de largura obviamente em busca de um caminho químico, e Synoeca surinama que também usa esta estratégia. Outro exemplo de migração difusa é dado por Jeanne (1975b) que observou a migração de uma população de Agelaia (= Stelopolybia) areata, estimada em 21.800 indivíduos. A outra forma de migração foi chamado de agrupamento temporário ("clumped swarm"), observado em Polybia ignobilis, Polybia raui e Parachartegus apicalis e em Polybia occidentalis (Forsyth, 1981), em que vários agrupamentos são formados em uma rota de migração e na mediada que a população avança na rota de migração os últimos agrupamentos vão se desfazendo. De acordo com West-Eberhard (1982), esta forma de deslocamento é mais lenta e facilita a orientação visual. Uma população migrante de Polybia raui formou agrupamentos próximos e durante duas horas não foi observado escoteiras fazendo "dragging", o mesmo ocorreu em uma população considerada grande de Parachartegus apicalis em que houve a formação de agrupamentos temporários e não foram observadas escoteiras fazendo "dragging". Por outro lado uma pequena população desta mesma espécie foi observada fazendo "dragging" e a migração foi difusa, provavelmente usaram orientação visual (West-Eberhard,1982). Em Apoica pallens ocorre a formação de agrupamentos (Howard et al., 2002; Hunt et al., 1995), porém diferente de outros Epiponini não fazem caminho químico usando algum tipo de substrato e também não selecionam um local para um novo ninho antes da migração. Depois da destruição do ninho as vespas formaram agrupamentos em folhas de plantas e o recrutamento foi feito quando as vespas elevavam o abdômen e expunham a base do $5^{\circ}$ e $6^{\circ}$ esternito. Este comportamento sugere que as vespas estão eliminando feromônio no ar ("calling display") para agrupar a população e conduzí-la até o novo local do ninho. Apesar do hábito noturno que envolve adaptações morfológicas, a migração desta espécie ocorreu durante o dia (Howard et al., 2002). 
Em P. fraternus o deslocamento das populações das 5 colônias estudadas com a remoção das estruturas do ninho seguiu o mesmo padrão, depois da seleção do novo local do ninho, da confecção do caminho químico e da sinalização para migrar feito pelas escoteiras, a população deixou o ninho gradualmente, voavam em círculos em volta do ninho original e saiam em busca do caminho químico, pousavam em folhas de árvores em volta do ninho original e seguiam a trilha deixada pelas escoteiras até atingir o local do novo ninho. É uma migração difusa mas com deslocamento massal da população. $\mathrm{Na}$ colônia C5 não houve a destruição do ninho, porém o comportamento da população durante o pré-enxameio, a confecção do caminho químico e a migração foram semelhantes as demais colônias estudadas.

Não foi observada a formação de agrupamentos temporários durante o deslocamento ao longo do caminho químico em $P$. fraternus como foram observados em A. pallida (Ducke, 1906) Polybia occidentalis (Forsyth, 1978, 1981), Agelaia (= Stelopolybia) areata (Jeanne, 1975b), Polybia sericea (Jeanne, 1981), Polybia ignobilis, Polybia raui e Parachartegus apicalis (West-Eberhard, 1982).

Algumas espécies de Epiponini Polybia sp., Polybia ignobilis, Polybia occidentalis, Protopolybia exigua e Agelaia pallipes foram observadas durante o deslocamento, quando centenas de indivíduos formavam agrupamentos preferencialmente em ponta de galhos com folhas. Foi observado um deslocamento difuso de Synoeca aff. chalybea, quando as vespas pousavam nas folhas de uma árvore isolada, procuravam pistas tocando com as antenas a superfície das folhas e, provavelmente, antes de voar deixavam pistas pois abriam as mandíbulas nas bordas da folha e voavam para outra folha. Uma população de Apoica throracica formou um agrupamento na ponta do galho de um arbusto 5 metros distantes do ninho original após tentativa de coleta da população (obs. Pessoal).

Em $P$. fraternus ficou muito evidente o sincronismo das atividades desempenhadas pelas escoteiras nos momentos que precederam a migração e o deslocamento massal da população; no local do novo ninho minutos antes da migração aumentou consideravelmente o número de escoteiras fazendo "dragging" e depositando veneno no substrato. As escoteiras se tornaram mais agitadas e rápidas na realização dos comportamentos, retornaram ao ninho original usando o caminho químico e sinalizaram para a população através de "dragging" e inúmeros contatos bucais de que era o momento de partir. O local 
do novo ninho já estava sinalizado assim como a trilha a seguir. Ocorreu uma revoada em volta do LNO e a maioria da população atingiu o LNN em poucos minutos.

\section{C.2.3 - Causas de migração forçada.}

A migração forçada "absconding swarms" seguida de abandono do ninho pode ser precedida por vários fatores, um dos principais inclui a predação por formigas (Richards \& Richards, 1951; Naumann, 1975; Chadad, 1979; West-Eberhard, 1978b; Jeanne, 1979), predação por morcegos danificando a estrutura do ninho (Jeanne, 1970), invasão do ninho por forideos (Schremmer, 1972; Simões et al., 1996), danos causados por chuvas pesadas (West-Eberhard, 1982; este trabalho). Embora se saiba que durante o processo de enxameio natural ou forçado possa ocorrer divisão populacional, em todas as colônias estudadas de $P$. fraternus as populações dos ninhos migraram para um mesmo local. Simões (1977) observou a fissão de uma colônia de Agelaia (= Stelopolybia) pallipes causado por formigas, e de acordo com Forsyth (1978) uma colônia de Metapolybia azteca dividiu após ataque de formigas. Foi observada também a fissão de uma colônia de Chartergellus communis que estava sob estudos com indivíduos codificados, durante a migração dividiu formando duas colônias (in prep.). Uma população de Parachartegus smithii abandonou o ninho e formou um agrupamento nas folhas da mesma árvore dois metros de distância do ninho original após o ninho ter sido invadido por formigas, a população permaneceu neste local por três dias (obs. pessoal).

\section{C.2.4 - A presença de machos nas migrações e em colônias em estabelecimento.}

A presença de machos foi constatada em 5 das 6 colônias de P. fraternus estudadas. Os machos não migraram com a população, permaneceram no ninho original. A presença de glândulas externas em machos de algumas espécies de Epiponini foi confirmada por (Downing et al., 1985). No gênero Apoica as glândulas do quinto esternito gastral são idênticas as das fêmeas, nos machos 
de Synoeca surinama, Agelaia (=Stelopolybia) areata e Pseudopolybia compressa luctuosa não foram encontradas glândulas nos esternitos gastrais (4-7). Em machos de Metapolybia docilis, Chartegus chartarius, Polybia liliacea, Polybia similliana e Polybia occidentalis as glândulas são do tipo III presentes no quinto esternito gastral.

Pouco se conhece sobre o comportamento de machos nas espécies de Epiponini, tampouco durante o processo de migração, porém machos do gênero Apoica tem glândulas externas idênticas às fêmeas. Provavelmente, devido a este fato são capazes de acompanhar a população durante a migração (Downing et al., 1985). Foi constatada a presença de machos em populações em estabelecimento ou então foram observados durante a migração. Ducke (1906) coletou um enxame de Apoica pallida com 5 machos e 200 fêmeas. Richards (1978) também encontrou machos em uma população de um ninho novo de Apoica flavissima. Howard et al., (2002) constatou a presença de machos em uma população de Apoica pallens durante a migração. Em uma colônia em estabelecimento de Apoica thoracica foram encontrados 4 machos e 481 fêmeas, em Protopolybia exigua foram encontrados machos em colônias em estabelecimento (obs. pessoal). West-Eberhard (1982) verificou a presença de machos em população de Leipomeles dorsata no primeiro dia de construção do ninho e em uma colônia pré-emergente de Parachartegus colobopterus. Machos de Provespa anomala não migram com a população de fêmeas (Matsuura, 1999). Estudos realizados com colônias de Polybia occidentalis, em que foi induzido o enxameio com a destruição dos ninhos, os machos não migraram (Bouwma et al., 2000, 2003). De acordo com os estudos de Strassmann et al., (1998), foram encontrados machos em colônias em estabelecimento de Protopolybia exigua $\left(\mathrm{n}^{\mathrm{o}}=\right.$ 10), Polybia occidentalis $\left(\mathrm{n}^{\mathrm{o}}=28\right)$ e Pa. colobopterus $\left(\mathrm{n}^{\mathrm{o}}=1\right)$, este resultado é diferente dos estudos de Bouwma et al., (2000) e Bouwma et al., (2003) e dos resultados obtidos neste trabalho. Em migrações forçadas ("absconding") como 
foi o caso deste estudo, os machos não acompanharam os enxames, a maioria eram machos jovens, por outro lado havia fêmeas jovens na população, é difícil determinar a causa da não migração dos machos.

\section{C.2.5 -A composição das populações em enxameio e em estabelecimento.}

A composição de populações originadas de colônias reprodutivas é ainda pobremente conhecida. Colônias em estabelecimento são freqüentemente encontradas embora na maioria das vezes se desconheça a causa da migração. Além disso, só uma refinada análise populacional, como verificação da idade relativa, padrões de ovários, ocorrência de inseminação em fêmeas com desenvolvimento ovariano etc., pode contribuir para determinar se uma colônia em estabelecimento representa um enxame reprodutivo ou uma migração forçada. Por exemplo, colônias de Metapolybia azteca e Polybia occidentalis coletadas durante a estação de enxameio (Forsyth, 1978; citado por West-Eberhard, 1982) seriam enxames reprodutivos, embora a idade relativa das populações não tenha sido verificada pelo autor. Forsyth (1978) encontrou grande variação na idade relativa entre os membros de 10 enxames de Polybia occidentalis e de Metapolybia azteca, assim como uma grande variação no número de rainhas presente em cada enxame. Neste campo, tivemos a oportunidade de analisar duas colônias pré-emergentes de Chartergellus communis: uma delas coletada em 12/05/99, continha um favo com 9 células e 8 ovos, 17 fêmeas adultas e uma rainha inseminada; a outra coletada em 02/07/99, continha dois favos com 23 ovos e 43 larvas jovens, além de 48 adultos e 8 rainhas inseminadas (Mateus, S. in prep). Todos os indivíduos das duas colônias

tinham os apódemas dos esternitos gastrais já pigmentados. Nesses casos, sugere-se que essas populações representem enxames reprodutivos, pois foram encontrados apenas indivíduos mais velhos, o mesmo foi verificado por Mateus et al., (2004), em uma população em estabelecimento. Desta forma, estes 
resultados diferem de Strassmann et al., (1998), em que afirma que as operárias de um enxame não formam uma classe específica de idade.

O número de rainhas nas colônias em estabelecimento é variável, de acordo com Strassmann et al., (1998) em 21 colônias de $P a$. colobopterus a média foi de 2 rainhas por colônia, variando de 0 até 9; em 7 colônias de Po. occidentalis a média foi de 12 rainhas, variando de 8 a 18; em 7 colônias de Pr. exigua a média foi de 13 rainhas, variando de 0 a 34. Em colônia órfã de Pa. colobopterus uma operária pode se tornar rainha de acordo com (Strassmann et al., 2002). Resultado semelhante foi observado neste trabalho. Por outro lado, colônia órfã de Protopolybia exigua coletada durante o estabelecimento (Strassmann et al., 1998; Gastreich et al., 1993), possa representar o fim da população, pois de acordo com Noll et al., (1996, 2004), rainhas de Protopolybia exigua são morfologicamente maiores que operárias, e a determinação é pré-imaginal, não há indícios de que uma operária desta espécie possa se tornar rainha.

Em enxames naturais o baixo grau de parentesco entre as operárias indica que vieram de colônias com muitas rainhas, por outro lado em colônias na fase de produção de fêmeas reprodutivas tem poucas rainhas e é alto o grau de parentesco entre as operárias (Strassmann et al., 1998), possivelmente em enxames reprodutivos as operárias tenham um alto o grau de parentesco.

\section{C.2.6 - Sobre o pré-enxameio e o papel das escoteiras de P. fraternus.}

O Pré-enxameio em $P$. fraternus foi caracterizado pela intensa movimentação de saídas e retornos das vespas ao ninho sem trazerem algum tipo de material de construção. O mesmo comportamento foi observado em Polybia occidentalis (Forsyth, 1981). A não reconstrução do invólucro danificado para observações de comportamento também foi forte indício de que a população estava prestes a abandonar o ninho. Outra marcante característica foi a intensa movimentação da população dentro do ninho (colônia C5), muitos contatos bucais principalmente dos indivíduos que retornam do campo e a 
remoção de larvas das células que eram maceradas e jogadas fora do ninho em vôo. As vespas realizavam vôos circulares em volta do ninho, voavam para as folhas mais próximas do ninho ou pousavam no invólucro entrando no ninho. O comportamento de "buzz running" foi observado no interior do ninho, sobre favos e substrato no início do pré-enxameio. Uma operária iniciava o comportamento que era desencadeado em outras operárias com duração variável. O "buzz running" ou "breaking behavior" (Naumann, 1975) é um comportamento de alarme amplamente utilizado pelas vespas sociais e observado em diversos gêneros (Naumann, 1975; Jeanne, 1975a; Forsyth, 1978; West-Eberhard, 1982; Ezenwa et al., 1998). É também usado para sinalizar a presença de parasitas sobre o invólucro do ninho e possíveis predadores (obs. Pessoal).

Em todos os casos aqui estudados, a migração de $P$. fraternus ocorreu depois de um período de pré-enxameio que variou de 50 até 74,5 horas (Tabela 2). Mesmo com a remoção das estruturas principais do ninho a população sempre retornou ao LNO e lá permaneceu até a migração, diferente de outras espécies que com a destruição do ninho formam agrupamentos próximos do ninho original (West-Eberhard, 1982). De acordo com nossos resultados, dois fatores estão relacionados com a duração do pré-enxameio, o primeiro é que os indivíduos não estão preparados fisiologicamente para esta atividade e segundo, as escoteiras precisam encontrar um local adequado para nidificação.

As escoteiras são aquelas fêmeas que durante o pré-enxameio se incumbem de selecionar o local para a construção do novo ninho. Nas 5 colônias de $P$. fraternus onde o enxameio foi induzido, elas iniciaram a busca logo que o ninho sofreu danos. Durante o pré-enxameio, a principal atividade das escoteiras está no estabelecimento do caminho químico entre o LNO e o LNN. Isso é feito pela deposição de produtos glandulares em folhas, ramos e em outros substratos disponíveis. No início as escoteiras voavam para todas as direções e visitavam vários substratos (tronco de árvores, galhos, postes, 
paredes etc). Após a seleção do LNN várias escoteiras passaram a freqüentar o local fazendo "dragging", tocando o substrato com as peças bucais, voando, pousando, etc. Ao retornarem ao LNO usavam o caminho químico já estabelecido. Com o aumento numérico das escoteiras no LNN, aumentava a agitação dos indivíduos e o início da deposição de veneno no substrato, indicando que a população estava prestes a migrar. Nesta fase, o número de escoteiras na trilha aumentava consideravelmente e os freqüentes retornos ao ninho original causavam muita agitação na população. As escoteiras faziam "dragging" no substrato do LNO e muitos contatos bucais estimulando a população a migrar, até que toda população iniciasse a migração para o novo local do ninho usando o caminho químico. Comportamento semelhante foi observado por Naumann (1970), durante o pré-enxameio em Protopolybia, em que as escoteiras que retornavam ao ninho original vibravam as asas e supostamente eliminavam alguma substância sobre o invólucro estimulando a migração. Durante o pré-enxameio as escoteiras mostraram-se flexíveis na realização de tarefas, uma vez que, além das atividades já mencionadas elas foram observadas realizando outras tarefas durante o início do estabelecimento como a construção de estruturas do ninho, atividades de forrageamento e defesa, postura de ovos no LNN (colônias C3 e C5) cuidados com a prole, construção de estruturas, forrageamento (colônia C5, produção de operárias).

\section{C.2.7 - A idade relativa das escoteiras da colônia C3.}

É pouco conhecida a identidade das escoteiras das diversas espécies de Epiponini estudadas. As escoteiras de P. fraternus da colônia C3 foram marcadas durante o pré-enxameio enquanto faziam "dragging" e depositavam veneno no local selecionado para a construção do novo ninho. Foram coletadas 
durante o estabelecimento para avaliar o desenvolvimento ovariano e a idade relativa. Durante o estabelecimento as escoteiras marcadas construíram estruturas do ninho, entre elas, uma intermediária realizou postura nas primeiras células construídas no novo local do ninho. E estava com os ovários desenvolvidos (padrão 5) e não inseminada (Mateus et. al., 2004). As demais escoteiras coletadas e dissecadas tinham ovários de padrão 1 e 2, a maioria tinha o apódema dos esternitos bem pigmentado, estas fêmeas foram observadas forrageando material de construção e água, construindo invólucro e favos durante o estabelecimento.

As escoteiras marcadas e não coletadas das demais colônias de $P$. fraternus foram observadas realizando tarefas de construção de célula e invólucro, forrageando água e polpa vegetal durante o estabelecimento, e horas antes da migração e na fase inicial do estabelecimento algumas delas foram observadas coletando polpa vegetal (material de construção) no ninho original.

\section{C.2.8 - As atividades das escoteiras de P. fraternus da colônia C5 durante a fase de produção de operárias.}

Na colônia C5 a população estava identificada com código de cores, estava sendo estudada desde 24/04/03. A atividade externa durante o préenxameio foi registrada em vídeo em 15/06/03 (13:31 até 16:10 horas), e em 16/06/03 (13:30 até 14:10 horas). Foram observadas 129 vespas marcadas em atividade, sendo possível verificar o tempo que algumas escoteiras ficaram fora do ninho, provavelmente, em busca do local do novo ninho; Foi registrado em vídeo as escoteiras que fizeram "dragging" e contato bucal na entrada do ninho. No total foram contados 441 saídas e 498 retornos de vespas marcadas. Na entrada do ninho foram contados 55 contatos bucais, observados 51 comportamentos de "dragging" feito por 20 escoteiras diferentes. E 30 vespas chegaram até a entrada e retornaram para o interior do ninho. Após a migração 
foram observadas 45 coletas de polpa no ninho original feita por escoteiras. As 20 escoteiras que fizeram "dragging" na entrada do ninho representaram 49,4\% do total de indivíduos que deixaram o ninho, 51,25\% de retornos, 74,55\% dos contatos bucais observados na entrada do ninho original, $46,66 \%$ das vespas que vieram até a entrada e retornaram para o interior do ninho e $88,88 \%$ dos indivíduos que coletaram polpa no ninho original durante o pré-enxameio. Duas rainhas foram observadas deixando e retornando ao ninho, uma rainha saiu e ficou fora do ninho durante 133 segundos, a outra rainha realizou duas viagens com duração de 41 e 48 seg. consecutivamente.

O comportamento de sinalização "dragging" é usado pelas vespas enxameadoras para sinalizar o caminho químico e conduzir a população até o local do novo ninho (Naumann, 1970; Jeanne, 1981, 1991; West-Eberhard, 1982). Em $P$. fraternus este comportamento foi amplamente utilizado pelas escoteiras para marcar o local do novo ninho e também para sinalizar o momento da migração. As escoteiras que fizeram “dragging” na entrada do ninho foram observadas anteriormente (fase de produção de operárias) forrageando água, polpa, presa e provavelmente néctar ou ficaram de guarda sobre o invólucro, portanto são forrageadoras experientes. Como exemplo citaremos alguns casos: a operária de código 51 realizou 11 comportamentos de "dragging" na entrada do ninho e fez 14 viagens como escoteira (duração média de 326,6 \pm 311,7 seg.). Anterior ao pré-enxameio esta operária foi observada sobre o invólucro do ninho na função de guarda por 44 vezes. A operária de código 240 realizou 6 comportamentos de "dragging" na entrada do ninho e realizou 4 viagens (duração média de 440,8 \pm 430,2 seg.). Anterior ao pré-enxameio foi observada construindo envelope e macerando polpa vegetal. A operária de código 40 fez 4 comportamentos de "dragging" na entrada do ninho, e durante o pré-enxameio realizou 3 viagens (duração média de 333,7 \pm 272,4 seg.). Anteriormente foi observada construindo envelope, fazendo contato bucal com larvas e macerando polpa, durante a observação de atividade externa realizou 5 viagens, provavelmente para coleta de néctar. A operária de código 129 durante o período de observação em vídeo realizou 26 saídas e 25 retornos, o tempo de 13 
viagens realizadas teve duração média de $272,2 \pm 284,8$ seg. A escoteira de código 117 foi uma importante forrageadora de presa, realizou 8 viagens durante o período de observação de atividade externa, também coletou água e provavelmente néctar. As operárias de códigos 51, 68 e 91 foram observadas como guarda sobre o invólucro.

Durante a fase de estabelecimento algumas escoteiras foram observadas em tarefas ligadas à construção do ninho e interação entre adultos, 4 escoteiras que foram observadas coletando material de construção na entrada do ninho original durante o pré-enxameio, elas continuaram retornando ao ninho original durante o estabelecimento para coleta de polpa vegetal. As escoteiras da colônia C5 que fizeram "dragging" na entrada do ninho e que foram discutidas nesta parte do trabalho foram marcadas 50 dias antes do processo de pré-enxameio, logo não eram jovens. A coleta de material vegetal para a construção do novo ninho iniciou antes da migração da população, algumas vespas foram observadas coletando polpa vegetal na entrada do ninho original ou no substrato dos ninhos que foram destruídos. Este comportamento provavelmente é uma pratica comum nesta espécie, pois foi observado na maioria das colônias estudadas.

\section{C.2.9 - As escoteiras e o recrutamento pós-migração.}

Verificamos neste estudo que o papel das escoteiras não termina com a confecção do caminho químico e da escolha do local do novo ninho. Várias escoteiras foram observadas percorrendo o caminho químico e retornando ao LNO após a migração, pousavam no substrato e andavam agitadamente entre os indivíduos que não haviam migrado, faziam "dragging" no substrato e contatos bucais, voavam em volta do agrupamento e voltavam para o LNN ou pousavam novamente no LNO, repetindo os mesmos comportamentos.

Com este comportamento as escoteiras estimulavam os indivíduos que restavam no ninho original a migrar. Estes resultados mostram que as escoteiras são flexíveis nas tarefas relacionadas às necessidades do ninho, esta 
flexibilidade observada entre as escoteiras na realização de tarefas durante a migração e estabelecimento, é decisiva para o sucesso do novo ninho.

\section{C.2.10 - Reforçando o caminho químico.}

Durante o pré-enxameio várias escoteiras foram observadas pousando nas mesmas folhas que foram utilizadas anteriormente por outra escoteira para fazer o caminho químico. Várias folhas de uma mesma árvore ou arbusto foram utilizadas como substrato. Sempre que pousavam em uma folha tocavam a superfície com as antenas fazendo o comportamento de "dragging", desta maneira reforçavam o caminho químico existente, e com o engajamento de novas escoteiras no grupo, conseqüentemente, o caminho químico ficava mais evidente (atrativo). O caminho químico foi reconhecido pelas escoteiras de um dia para outro, pois utilizaram a mesma direção e substratos do dia anterior. Jeanne (1986) observou o mesmo fenômeno em Polybia occidentalis.

Segundo alguns autores, as escoteiras durante o enxameio estão envolvidas em diferentes tarefas, e assim, formam uma equipe com diversas sub tarefas (Jeanne, 1986; Jeanne, 2003; Anderson \& Ratnieks, 1999; Ratnieks \& Anderson, 1999).

\section{C.2.11 - A eficiência do caminho químico e a perda de indivíduos.}

O caminho químico feito pelas escoteiras entre o LNO e o LNN utilizado pela população durante a migração foi muito eficiente nesta espécie, pois todas as operárias e rainhas das colônias estudadas migraram atingindo o LNN, exceto na colônia $\mathrm{C} 2$, onde uma rainha desapareceu não atingindo o LNN e outra que foi coletada no final do dia no ninho original para checar inseminação e idade relativa. A perda de força de trabalho no novo ninho certamente pode trazer graves conseqüências na fase inicial do estabelecimento, operárias construtoras e forrageadoras de polpa e água são imprescindíveis. A população fica vulnerável ao ataque de predadores na fase inicial do estabelecimento e, assim, dezenas de operárias ficam de guarda em volta do grupo garantindo a 
segurança. A perda de indivíduos durante o enxameio certamente afetaria os níveis de produtividade de futuras gerações. Nas colônias estudadas foi observado um grande número de indivíduos inativos no ninho durante o préenxameio e estabelecimento, estimado de 60 a 70\% da população, os ninhos estavam na fase de produção de operárias e de machos, provavelmente grande parte da população era de jovens, supostamente não preparados ainda para tarefas de forrageio ou de construção.

Neste trabalho não foi avaliada a perda de indivíduos durante a migração, no entanto, não restaram operárias no LNO e também não ocorreu a divisão das colônias estudadas. Um estudo realizado com 27 colônias de Polybia occidentalis em condição de migração forçada revelou que ocorre uma pequena perda de indivíduos durante a migração independente da distância, no entanto não causa impacto no início da nova colônia, esta perda é atribuída a predação e a indivíduos jovens que não acompanham o caminho químico (Bouwma et al., 2003). Os métodos utilizados nos dois trabalhos foram diferentes, assim como a forma de migração de cada espécie estudada.

\section{C.2.12 - Marcar o novo local do ninho depositando veneno.}

Foram encontrados agrupamentos de escoteiras de $P$. fraternus no LNN de 4 colônias estudadas (colônias C1, C2, C3 e C5) antes de ocorrer a migração. A Figura 3 B, C e D mostram o pequeno número de escoteiras nesta fase inicial. As escoteiras das colônias C1 e C3 no dia anterior a migração foram localizadas no LNN. O comportamento das escoteiras foi semelhante em todos os casos observados, ou seja, tocavam o substrato com as antenas e aparelho bucal (Fig. 3 D), em movimento pressionavam os esternitos gastrais no substrato percorrendo curta distância com leves movimentos laterais do abdômen (Fig. 3 B). E repetia o mesmo comportamento ou voavam em círculos em volta do LNN. A quantidade de escoteiras no LNN aumentou gradativamente, ficavam

mais agitadas, flexionavam o abdômen em rápidos movimentos laterais e durante parada súbita o abdômen era curvado, a extremidade distal 
direcionada para o substrato e contraído rapidamente depositando veneno várias vezes durante uma corrida (Fig. 3 C e D). Freqüentemente a extremidade distal do abdômen tocava o substrato, em seguida, repetiam o mesmo comportamento ou faziam vôos circulares em volta. O substrato do local do novo ninho foi intensamente tocado com o aparelho bucal pelas escoteiras.

Com o aumento de escoteiras no LNN e a aproximação do momento da migração, as escoteiras percorriam maior distância no substrato fazendo "dragging" e aumentavam o número de vezes que aspergiam veneno no substrato. Na colônia $\mathrm{C}$, horas antes da migração foi medido o tempo de duração do comportamento de "dragging" e de depositar veneno no substrato de 15 escoteiras das 9:00 às 11:00 horas (a média foi de 4,28 $\pm 1,46$ seg.), e das 11:00 às 11:30 horas de 23 escoteiras (a média foi de 6,83 e $\pm 4,12$ seg.). Na colônia C2 foi medido o tempo da duração do comportamento de "dragging" e de depositar veneno no substrato quando no agrupamento havia 10 escoteiras (a média foi de 2,98 $\pm 0,61$ seg.). O número de indivíduos LNN aumentou rapidamente, as escoteiras percorriam maior distância fazendo "dragging" e depositavam veneno simultaneamente, foi medido o tempo de 6 escoteiras fazendo estes comportamentos pouco antes da migração (a média foi de 7,64 \pm 2,78 seg.). Com a aproximação do momento da migração as escoteiras percorriam maior distância fazendo "dragging" e depositando veneno, várias vezes no substrato durante uma mesma corrida. Possivelmente, esta aplicação de veneno no LNN possa servir para eliminar possíveis parasitas ou outros organismos que possam causar danos futuros, e também mantendo outros predadores distantes tais como as formigas.

O veneno aplicado possivelmente tem ação fungicida e bactericida, como verificada em algumas espécies de formigas (Maschwitz \& Kloft, 1971). Posteriormente o substrato será coberto com material vegetal fibroso, o mesmo utilizado na construção de favos e invólucro. Em uma colônia em estabelecimento de Polybia occidentalis as escoteiras aplicaram secreção oral na área central do agrupamento do local do novo ninho antes de iniciar a 
construção do ninho (Forsyth, 1981), possivelmente deve ter relação com a defesa contra formigas.

\section{C.2.13 - A sinalização para migrar e o ponto final do caminho químico.}

O movimento coordenado da população durante a migração depende dos sinais químicos deixado pelas escoteiras em diferentes substratos indicando uma direção a seguir (Naumann, 1975; Jeanne, 1975a; Forsyth, 1978; WestEberhard, 1982).

Em $P$. fraternus o ponto final do caminho químico foi sinalizado com veneno por dezenas de escoteiras criando uma área de fácil reconhecimento devido ao forte odor da substância aplicada no substrato. Nos momentos que antecedem a migração o número de escoteiras depositando veneno no substrato do LNN é elevado, simultaneamente no LNO as escoteiras que lá retornaram faziam "dragging" no substrato e inúmeros contatos bucais, desta forma sinalizando e estimulando a população a migrar.

A migração difusa é rápida e contínua, ao atingir o LNN os indivíduos da população voavam em volta do local marcado determinado pelas escoteiras, pousando em seguida sempre tocando a superfície do substrato com o aparelho bucal, assim como realizando vários contatos bucais. O comportamento de depositar veneno no substrato continuava mesmo com a chegada da maior parte da população. Em algumas colônias o comportamento de depositar veneno durou até o início da construção dos pedúnculos. Devido à curta distância entre o observador e o LNN, onde dezenas de escoteiras depositaram veneno (durante a realização de vídeo) foi possível sentir o odor do veneno expelido e o efeito causado na pele, olhos e mucosa devido à reação alérgica. A estratégia de marcar o LNN com veneno certamente indica o ponto final da migração devido a grande quantidade de substância química expelida criando uma área de fácil reconhecimento para a população enxameante. 


\section{C.2.14 - A distância da migração.}

As distâncias de migração das populações de $P$. fraternus foram variáveis (Tabela 2), sendo a média para as 6 colônias estudadas de 36,16 metros. A distância mínima observada foi de 28 metros e a máxima de 75 metros. As escoteiras são as responsáveis pela escolha de um local que atenda as necessidades da população para a construção do novo ninho, esta escolha inclui o tipo de substrato, altura do solo, incidência de luz solar e, provavelmente, disponibilidade de água e de alimento. $\mathrm{O}$ item distância provavelmente está mais relacionado com boas condições para o desenvolvimento da colônia. As escoteiras são indivíduos mais velhos da população e forrageadoras experientes (como confirmado na colônia C5). De acordo com Mateus et al., (2004), em uma colônia de $P$. fraternus em estabelecimento não havia fêmeas jovens, logo as escoteiras foram fêmeas mais velhas. Segundo Forsyth (1978), em Polybia occidentalis ninhos novos são formados por operárias e rainhas mais velhas.

A distância de enxameio induzido em 102 colônias de Polybia occidentalis foi de 0 a 115 metros, o tamanho da população não influenciou na distância de migração (Bouwma et al., 2003). Colônias de Metapolybia aztecoides foram encontradas 20 metros do ninho original, e de Polybia sericea a 250 metros do ninho original (West-Eberhard, 1982). Jeanne (1975b) observou a migração de uma colônia de Agelaia (= Stelopolybia) areata a 319 metros de distância do ninho original. Forsyth (1978) sugeriu que a distância de migração provavelmente é o limite máximo da área de forrageio; Neste estudo acreditamos que a distância das migrações está mais relacionada com a disponibilidade de recursos. Seguramente a distância de forrageio ultrapassa a distância máxima de migração observada neste estudo, entretanto, pouco se sabe sobre a distância de forrageio das espécies de Epiponini até agora estudadas. 
Tabela 2. Código das colônias estudadas, início do pré-enxameio, duração do pré-enxameio, data e duração da migração, duração, distância da migração, substrato do novo ninho e população estimada no início dos estudos.

\begin{tabular}{|c|c|c|c|c|c|c|c|}
\hline $\begin{array}{l}\text { Código das } \\
\text { colônias }\end{array}$ & $\begin{array}{l}\text { Pré-enxameio, } \\
\text { início }\end{array}$ & $\begin{array}{c}\text { Pré-enxameio, } \\
\text { duração }\end{array}$ & $\begin{array}{l}\text { Duração da } \\
\text { migração }\end{array}$ & $\begin{array}{l}\text { Data e hora da } \\
\text { migração }\end{array}$ & $\begin{array}{l}\text { Distância da } \\
\text { migração }\end{array}$ & $\begin{array}{c}\text { Tipo de } \\
\text { substrato } \\
\text { escolhido } \\
\end{array}$ & $\begin{array}{c}\text { População } \\
\text { estimada em } \\
\text { vídeo } \\
\end{array}$ \\
\hline C 1 & $\begin{array}{c}25 / 02 / 00 \\
10: 35 \text { horas }\end{array}$ & 50 horas & 30 minutos & $\begin{array}{c}\text { 27/02/00 } \\
\text { 11:30 horas }\end{array}$ & 28 metros & $\begin{array}{l}\text { coluna de } \\
\text { madeira }\end{array}$ & 290 vespas \\
\hline C 2 & $\begin{array}{l}22 / 03 / 00 \\
9: 00 \text { horas }\end{array}$ & 74,5 horas & 25 minutos & $\begin{array}{c}\text { 25/03/01 } \\
\text { 11:30 horas }\end{array}$ & 30 metros & galho de árvore & 270 vespas \\
\hline C 3 & $\begin{array}{c}\text { 03/03/03 } \\
\text { 11:30 horas }\end{array}$ & 48 horas & 35 minutos & $\begin{array}{c}\text { 05/03/03 } \\
\text { 11:23 horas }\end{array}$ & 28 metros & $\begin{array}{l}\text { coluna de } \\
\text { madeira }\end{array}$ & 350 vespas \\
\hline C 4 & $\begin{array}{c}\text { 03/03/03 } \\
\text { 14:30 horas }\end{array}$ & 49 horas & Não observado & $\begin{array}{c}\text { 05/03/03 } \\
\text { entre 12:15-13:35 } \\
\text { horas }\end{array}$ & 75 metros & tronco de árvore & 360 vespas \\
\hline C 5 & $\begin{array}{l}14 / 06 / 03 \\
8: 00 \text { horas }\end{array}$ & 55 horas & 25 minutos & $\begin{array}{c}\text { 16/06/03 } \\
\text { 15:00 horas }\end{array}$ & 26 metros & galho de árvore & 340 vespas \\
\hline C 6 & $\begin{array}{c}\text { 23/03/04 } \\
\text { 18:30 horas }\end{array}$ & 67 horas & Não observado & $\begin{array}{c}\text { 26/03/04 } \\
\text { entre 12:50-13:45 } \\
\text { horas }\end{array}$ & 33 metros & galho de árvore & 320 vespas \\
\hline
\end{tabular}



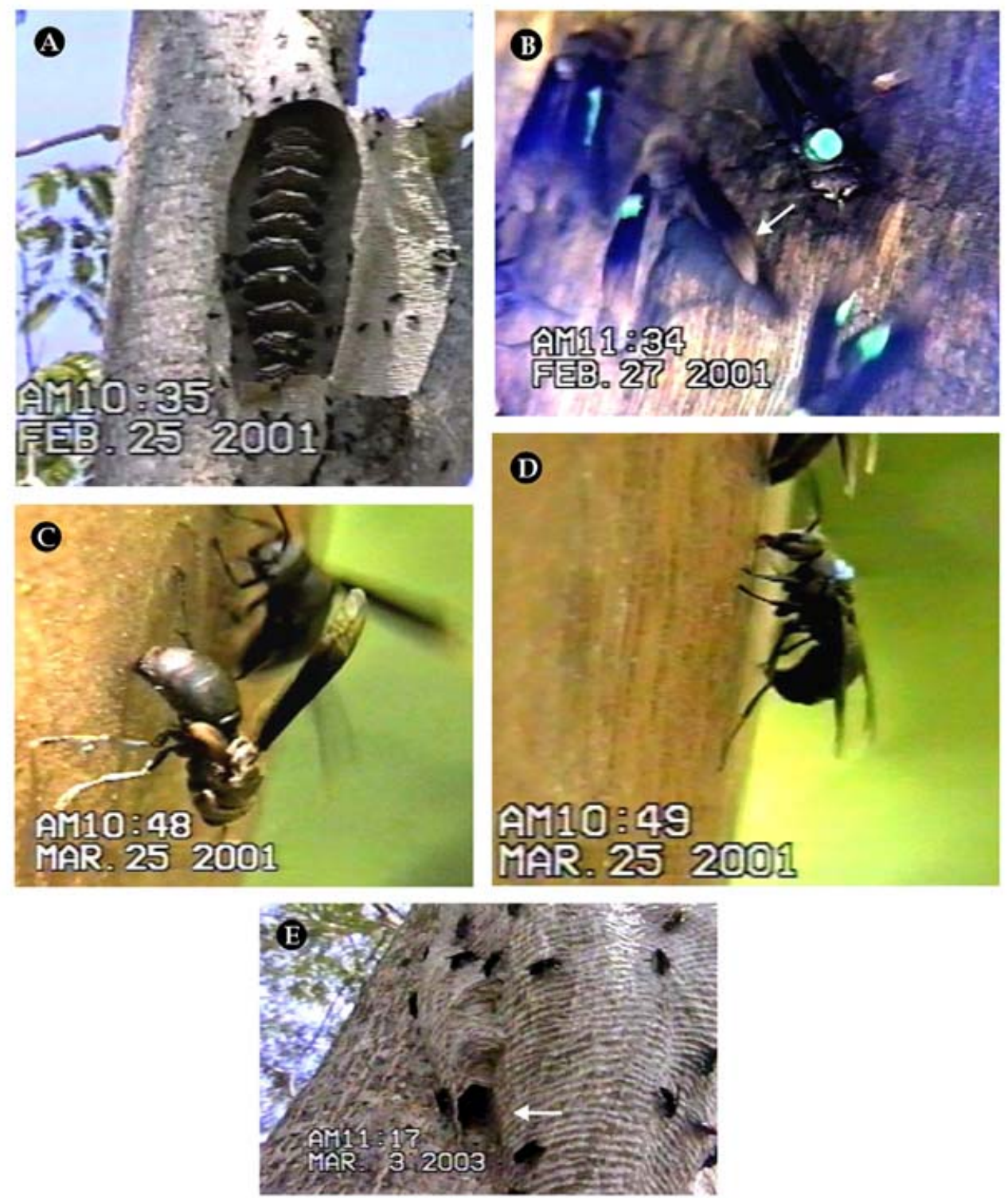

Figura 3. Fase de pré-enxameio, colônia C1: A - ninho com invólucro parcialmente aberto; B - escoteiras marcadas no LNN, seta indica uma escoteira fazendo “dragging”. Fase de pré-enxameio, colônia C2: C - escoteira depositando veneno no substrato no LNN; D - escoteira que foi marcada no caminho químico, depositando veneno no substrato no LNN. Fase de pré-enxameio, colônia C3: E - câmara construída na lateral do invólucro e no substrato, onde estavam abrigadas algumas intermediárias e operárias, a seta indica a entrada. 


\section{C.3 - Análise dos comportamentos envolvidos em aspectos essenciais da dinâmica colonial de Parachartergus fraternus (Hymenoptera: Vespidae: Epiponini).}

\section{C.3.1 - Comportamento das rainhas durante a fase de produção de operárias da colônia C5.}

Os estudos dos aspectos do comportamento de rainhas, intermediárias e operárias na fase de produção de operárias da colônia C5 iniciaram-se em 24/04/03 e continuaram até 14/06/03 quando a população apresentou comportamento de pré-enxameio. Durante esta fase, havia 10 rainhas identificadas com código de cores no ninho. Além dessas, foram observadas outras rainhas (indivíduos que apresentavam síndrome comportamental afim) não marcadas, realizando postura e interagindo com as rainhas marcadas. As rainhas conviveram pacificamente. Nesta fase as rainhas se locomoviam pelos favos fazendo muitos contatos bucais com larvas e operárias e também inspeção em células. A Tabela 3 apresenta os principais atos comportamentais realizados pelas rainhas nesta fase.

Não foi observada área de domínio ou território nos favos. Elas se locomoviam por todos os favos e, também, ficavam paradas no substrato ou embaixo dos favos. Foram observadas 18 posturas. Destas, 13 foram medidas e apresentaram uma duração média de 55,80 $\pm 16,80 \mathrm{seg}$. A inspeção de célula antes da postura $\left(n^{\circ}=9\right)$, durou $14,63 \pm 6,69$ seg. A duração de 13 fixações de ovos após a postura foi de 45,17 $\pm 15,33 \mathrm{seg}$. A duração das posturas das rainhas está representada na Tabela 4. Não houve diferença significativa entre a duração das posturas das rainhas (One way ANOVA, $p=0,342$ ). A rainha R3VD realizou mais atos comportamentais do que as demais, no entanto, não foi observada diferença significativa entre as rainhas no número de atos comportamentais ligados a reprodução (One way ANOVA, p =0,037). As rainhas sempre fazem inspeção no interior das células antes de fazerem a postura e, imediatamente, após a postura fixam e lambem o ovo. Durante a 
fixação do ovo recém botado outras rainhas podem se aproximar e mordiscar o abdômen ou as pernas, ou empurrar com a cabeça a rainha que estava com a cabeça no interior da célula impedindo-a de continuar (Tabela 3). Assim essa rainha deixava a célula e aquela que forçou sua retirada, passava a fixar e lamber o ovo, no entanto não foi observada diferença significativa com relação às interações competitivas entre as rainhas (One way ANOVA, p =0,070). Nesta fase, não se observou oofagia, porém não podemos descartar a possibilidade de sua ocorrência.

\section{C.3.1.1 - Comportamento das intermediárias durante a fase de produção de operárias da colônia C5.}

Durante o período de estudos desta fase da colônia não foram observadas intermediárias realizando postura ou outro comportamento que denotasse o status afim. Estes indivíduos provavelmente já estavam com os ovários desenvolvidos, sendo possível que fossem impedidas de botar pela presença das rainhas existentes na colônia. Essas intermediárias já estavam identificadas com código de cores e, portanto, elas puderam ser identificadas na realização de tarefas relacionadas com a construção do ninho, tais como a construção do invólucro, macerar e dividir polpa. Também foram observadas em interações com adultos, forrageio e cuidados com a prole. A Tabela 5 apresenta os principais atos comportamentais relacionados com as tarefas realizadas por cada intermediária. Posteriormente, durante o estabelecimento da colônia, elas foram observadas realizando posturas.

Durante o pré-enxameio as intermediárias foram observadas saindo e retornando ao ninho. Foram também, observadas na entrada do ninho fazendo contato bucal com as vespas que retornavam do campo. Durante as observações de atividade externa e forrageio, a intermediária de código 71 realizou 5 viagens, provavelmente para a coleta de néctar e numa das viagens retornou com água (abdômen dilatado). A intermediária de código 90 foi observada na atividade de guarda sobre o invólucro $\left(n^{\circ}=3\right)$. Ela realizou também 3 viagens, provavelmente para coleta de néctar. A intermediária de código 137 fez uma viagem, provavelmente para coleta de néctar. 
Tabela 3. Frequiência de atos comportamentais (\%) observados durante a fase de produção de operárias da colônia C5 envolvendo as rainhas. Duração: início 24/04/03 a 14/06/03 (tempo cumulativo das observações em vídeo, 19 horas e 30 minutos). As siglas utilizadas para descrever os atos comportamentais das rainhas foram descritas no item Material e Métodos (página 18).

\begin{tabular}{cccccccccc}
\hline $\begin{array}{c}\text { Código das } \\
\text { rainhas }\end{array}$ & IC & PO & FXO & AL & TR & RR & RT & CBL & $\begin{array}{c}\text { Total de atos } \\
\text { realizados } \\
\text { por rainha }\end{array}$ \\
\hline R2VD & 21,43 & 11,11 & 15,38 & 50,00 & 50,00 & 12,50 & 12,50 & 18,26 & 34 \\
R3AM & 21,43 & 16,67 & 15,38 & - & - & 25,00 & - & 20,87 & 34 \\
R3BR & 7,14 & - & - & - & 50,00 & - & - & 13,04 & 19 \\
R3VD & 42,86 & 22,22 & 23,08 & 50,00 & - & 37,50 & 50,00 & 21,74 & 46 \\
RG30 & 7,14 & 11,11 & 15,38 & - & - & 12,50 & 12,50 & 6,09 & 14 \\
RG3P & - & - & - & - & - & - & - & 0,87 & 1 \\
RGAD & - & 27,78 & 23,08 & - & - & - & - & 15,65 & 26 \\
RGAE & - & 5,56 & - & - & - & - & 12,50 & 0,87 & 3 \\
RGLD & - & - & - & - & - & - & - & 1,74 & 2 \\
RGTE & - & 5,56 & 7,69 & - & - & 12,50 & 12,50 & 0,87 & 5 \\
Total por & 14 & 18 & 13 & 2 & 6 & 8 & 8 & 115 & 184 \\
categoria & 14 & & & & & & & & \\
\hline
\end{tabular}

Tabela 4. Número de posturas realizadas por algumas das rainhas da colônia C5 durante a fase de produção de operárias da colônia C5. Duração: início 24/04/03 a 14/06/03 (tempo cumulativo das observações em vídeo, 19 horas e 30 minutos).

\begin{tabular}{ccccc}
\hline Rainhas & $\begin{array}{c}\text { Número de casos } \\
\text { observados }\end{array}$ & $\begin{array}{c}\text { Duração mínima } \\
\text { em segundos }\end{array}$ & $\begin{array}{c}\text { Duração máxima } \\
\text { em segundos }\end{array}$ & Médias \pm DP \\
\hline R3AM & 2 & 65 & 70 & $67,5 \pm 3,53$ \\
R3VD & 4 & 41 & 56 & $48,5 \pm 7,59$ \\
RGAD & 5 & 51 & 100 & $66 \pm 20,34$ \\
RG30 & 2 & 50 & 52 & $51 \pm 1,41$ \\
- & 13 & 51,75 & 69,51 & - \\
\hline
\end{tabular}


Tabela 5. Freqüência de atos comportamentais (\%) observados durante a fase de produção de operárias da colônia C5 envolvendo as intermediárias. Duração: início 24/04/ 03 a 14/06/03 (tempo cumulativo das observações em vídeo, 19 horas e 30 minutos). As siglas utilizadas para descrever os atos comportamentais das intermediárias foram descritas no item Material e Métodos (página 20).

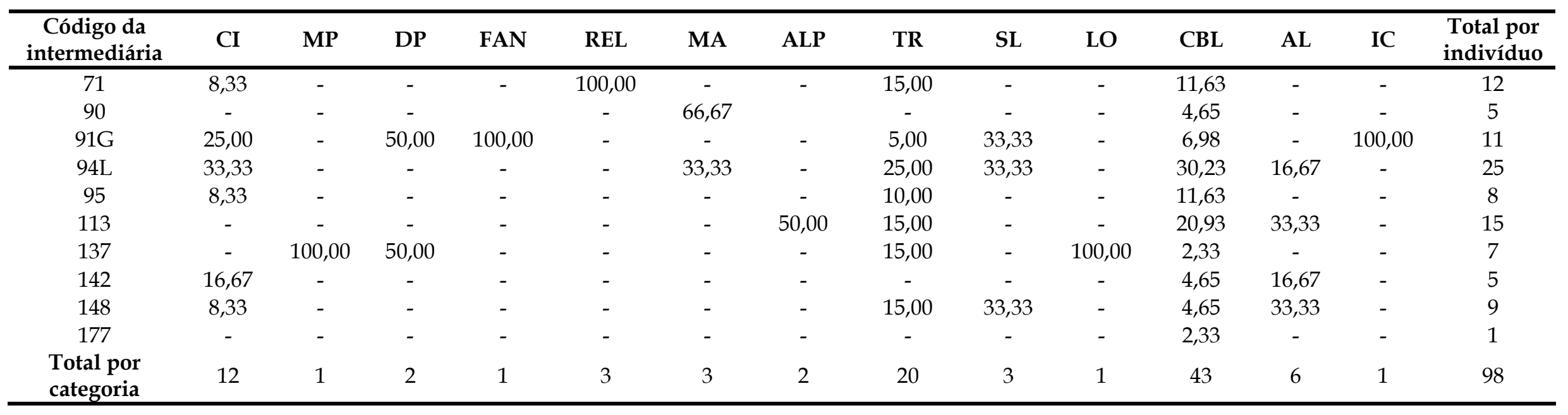




\section{C.3.2 - Fase de pré-enxameio das colônias estudadas}

\section{C.3.2.1 - Comportamento das rainhas da colônia C1 durante o pré-enxameio.}

As rainhas $(\mathrm{n}=11)$ foram identificadas e marcadas com código de cores logo após a remoção do invólucro e dos favos. Para isso, elas não foram removidas do substrato do ninho original. O repertório comportamental de rainha difere muito de operárias, as rainhas são mais lentas do que as operárias quando andam, curvam o abdômen para outros membros da colônia ou para outra rainha, as asas ficam levemente abertas quando paradas, não participam da construção ou manutenção do ninho, não forrageiam, raramente deixam o ninho, têm o abdômen mais alongado (distendido), a área de sobreposição entre os tergos fica exposta e é brilhante, a postura de uma rainha é composta por três etapas distintas: inspeção de célula, postura e fixação do ovo. Apesar de não apresentarem diferenças morfométricas evidentes (Mateus et al., 2004), foi possível reconhecer as rainhas observando as características descritas acima.

A Tabela 6 enumera os principais e os mais freqüentes atos comportamentais realizados pelas rainhas da colônia C1 durante o pré-enxameio.

As rainhas ficavam paradas no substrato próximas uma das outras, agrupadas sem contato corporal, e formavam grupos de 2 até 5 rainhas (Fig. 4 A). Com a grande movimentação das operárias e de escoteiras que retornavam ao ninho original estes agrupamentos de rainhas variavam em número e local no substrato. Quando próximas umas das outras esfregavam as pernas posteriores nos esternitos abdominais e passavam sobre o abdômen e asas, provavelmente, espalhando feromônios. Outro comportamento observado com freqüência foi o contato corporal entre elas, uma rainha aproxima-se de outra, encostava o corpo lateralmente na outra rainha, aparentemente forçando lateralmente um contato corporal por alguns instantes, este comportamento ocorreu entre duas e até 5 rainhas (Fig. 4 B) desfazendo, rapidamente, com as rainhas afastando-se umas das outras.

As rainhas, com freqüência, curvavam o abdômen para as operárias e para rainhas que passavam próxima ou que se aproximavam, permanecendo 
assim por alguns instantes, repetindo o comportamento com a aproximação de outro indivíduo (Fig. 4 C). Entre as rainhas, não foi observada diferença estatisticamente significante no número de atos comportamentais de curvar o abdômen (One way ANOVA, $\mathrm{p}=0$,207). Durante este comportamento não foi observado qualquer tipo de agressão física ou contato por parte das rainhas em outros membros da colônia, este comportamento, certamente ritualizado, está possivelmente relacionado com uma forma de proteção ou defesa das rainhas. Porém, como a realização deste comportamento não serviu para afastar as operárias ou rainhas, pode se supor, também, que o ato possa representar a ritualização dos comportamentos que expressa dominância. Rainhas também foram observadas completamente paradas e distantes umas das outras. Poucos contatos bucais foram observados entre rainhas. No entanto, o contato bucal entre rainhas e operárias foi mais freqüente do que entre rainhas. A solicitação de contato bucal sempre foi iniciada pelas rainhas que avançavam sobre as operárias prendendo-as com o primeiro par de pernas. Geralmente as operárias evitavam esse contato.

Durante o pré enxameio, com a remoção total de favos e invólucro, não foi observado nenhum tipo de reação agressiva entre os membros da população, isto é, as rainhas foram praticamente ignoradas pelas operárias. Toda a movimentação da população no ninho original ocorreu em torno dos comportamentos apresentados pelas escoteiras que nesta fase desempenham o papel mais importante entre os demais membros da população.

\section{C.3.2.2 - Comportamento das rainhas da colônia C2 durante o pré-enxameio.}

O invólucro e os favos da colônia 2 foram removidos em 22/03/01 as 10:30 horas (início do pré-enxameio). Foram identificadas e marcadas no tórax com tinta 10 rainhas sem serem removidas do substrato do ninho original. As rainhas permaneceram no local do ninho original com as operárias. A Tabela 7 enumera os principais e mais freqüentes atos comportamentais realizados pelas rainhas durante o pré-enxameio que teve a duração de 74,5 horas. 
O comportamento das rainhas diferiu em alguns aspectos do que foi observado entre as rainhas da colônia $\mathrm{C} 1$, as quais sempre curvavam o abdômen para outras rainhas e para operárias enquanto se locomoviam ou quando estavam paradas no substrato, porém na colônia C2 as rainhas nunca tiveram contato corporal, sempre ficaram distantes umas das outras e raramente foram observadas próximas umas das outras. Diferente do observado na colônia $\mathrm{C} 1$, quando uma rainha detectava a presença de outra rainha afastava rapidamente. As rainhas fizeram muita solicitação de alimento para as operárias que, na maioria das vezes, fugiam. Eram atraídas quando forrageadoras pousavam com presa e participavam da divisão do alimento. As forrageadoras de presa continuaram a forragear mesmo com a destruição do ninho. Duas rainhas foram observadas deixando o ninho original em vôo e retornando posteriormente.

O comportamento das rainhas não alterou desde o início das observações, elas ficavam parte do tempo paradas no substrato do ninho original. O comportamento de auto-limpeza ("grooming") teve baixa freqüência, as rainhas desta colônia raramente ficavam próximas umas das outras, diferente do que foi observado entre as rainhas da colônia C1. Com a grande movimentação das escoteiras no ninho original sinalizando para a população migrar, as rainhas deixavam o ninho original com a maioria da população seguindo o caminho químico até o local do novo ninho.

\section{C.3.2.3 - Eliminação de rainhas pelas operárias durante o pré-enxameio na colônia C5.}

Os estudos dos aspectos do comportamento de rainhas, intermediárias e operárias da colônia C5 iniciaram em 24/04/03, porém em 14/06/03 o comportamento das operárias apresentou fortes características de préenxameio. O invólucro do ninho que foi afastado para observação não foi reconstruído e as operárias que retornavam ao ninho não traziam alimento ou material de construção. Algumas operárias estavam removendo imaturos das células, macerando-os ou jogando-os fora em vôo. Muitas operárias deixavam o 
ninho, pousavam em folhas de árvores próximas e retornavam ao ninho. Outros detalhes dos comportamentos relacionados ao pré-enxameio e a migração desta população foi apresentada em outro tópico (Análise cronológica do processo de enxameio, colônia C5). O pré-enxameio teve duração de 55 horas, iniciou em 14/06/03 e a população migrou em 17/06/03.

No ninho havia 10 rainhas identificadas com cores no tórax. Algumas delas passaram a receber agressões físicas. Os ataques eram rápidos e a agressora, sempre a mesma operária, tentava prender a rainha agredida pela base das asas que, as vezes, podiam ser amputadas, como observado na colônia C3. Foram vários ataques de uma única operária em várias rainhas que estavam sobre o invólucro. Provavelmente, estas rainhas já estavam sendo agredidas no interior do ninho. A operária de código 91 foi a única agressora de rainhas observada durante o pré-enxameio. Anteriormente esta operária foi observada em atividades de construção de ninho e de guarda sobre o invólucro.

Duas rainhas (R3BR e ROE) estavam paradas sobre o invólucro em contato corporal, a operária de número 91 aproximou-se e imediatamente atacou uma delas. É importante notar que o ataque ocorreu sem qualquer outro comportamento prévio, ou contatos como observado em outras espécies (WestEberhard, 1978a; Nascimento, 2003). Com as mandíbulas a operária prendeu a rainha pelas asas e as duas caíram do invólucro. Novamente às 16:00 horas, a mesma operária (91) atacou outra rainha (RGAD) que estava parada sobre o invólucro, a agressora se locomoveu em volta da rainha e tentou segurá-la pelas asas. A rainha ficou de frente para a agressora, quando a operária conseguiu prender a rainha pelas asas tentando cortá-las com as mandíbulas, a rainha reagiu com mordidas, as duas caíram do invólucro. Em geral as rainhas reagiam pouco aos ataques da operária. Sempre que eram ameaçadas fugiam. Outras operárias foram observadas próximas das rainhas sobre o invólucro, mas não se mostraram agressivas.

Em 15/06/03, no período da tarde, havia 3 rainhas (R2VD, R3BR e ROE) sobre o invólucro e novamente a mesma operária (91) atacou as rainhas da mesma forma que atacou outras rainhas no dia anterior. As rainhas fugiram 
após os ataques e pousaram em folhas da árvore onde estava localizado o ninho. Duas rainhas foram observadas entrando no ninho as 16 horas e 10 minutos, a R3VD e R3BR, antes de entrar no ninho foram reconhecidas, tocadas com as antenas por algumas operárias que estavam na entrada do ninho. Após alguns minutos, uma delas, a R3BR caiu dentro do saco coletor de lixo mantido abaixo do ninho sendo atacada por uma operária não identificada. A rainha escapou da operária e voou.

Em 16/06/03 havia muitas operárias fora do ninho próximas da entrada. A operária de código 91 estava de guarda na entrada do ninho e atacou uma rainha (RGAD) que tentou entrar no ninho. As duas caíram dentro do saco coletor de lixo abaixo da entrada do ninho, a rainha conseguiu escapar do ataque e fugiu voando. Duas rainhas foram coletadas após sucessivos ataques, a rainha $\mathrm{R} 2 \mathrm{VD}$ que estava refugiada em folha de árvore próxima ao ninho e a rainha RGAD que estava dentro do saco coletor de lixo com as asas danificadas incapaz de voar. Posteriormente as rainhas foram dissecadas e observou-se que estavam inseminadas com ovários de padrão 5 e não eram jovens (Mateus et al., 2004). Havia também um macho jovem dentro do saco coletor de lixo. A rainha R3VD foi observada entrando no ninho sem ser molestada pelas operárias que estavam de guarda na entrada. Havia grande movimentação de escoteiras no ninho, muitas arrastavam o abdômen no substrato próximo a entrada do ninho e em folhas de árvores próximas do ninho. Grande parte da população já estava percorrendo o caminho químico feito pelas escoteiras.

As 15:00 horas dezenas de vespas voavam em volta do ninho, foi o início da migração, havia muitas vespas percorrendo o caminho químico até o local do novo ninho localizado em um arbusto a 30 metros do ninho original. Após a migração da população, no ninho original restaram três rainhas marcadas, operárias sem marcas e alguns machos.

Em 17/06/03 no ninho original restavam alguns machos e 3 rainhas (R3AM, R3BR, R30G) que foram agredidas anteriormente e no momento da migração provavelmente não estavam com a da população. As forrageadoras que retornavam ao ninho original para coletar polpa vegetal faziam contatos 
bucais com os indivíduos que não acompanharam o enxame. As rainhas que restaram no ninho original foram, posteriormente, observadas no novo ninho no período da tarde, conseguiram reconhecer o caminho químico, e no LNN não estavam sendo agredidas por nenhuma operária. Como o invólucro estava fechado não foi possível observar o comportamento no interior do ninho. As rainhas que foram observadas sobre o invólucro foram atacadas várias vezes por uma única operária. Três rainhas que foram atacadas desapareceram e duas foram coletadas em 16/06/03. Não foi possível identificar as causas dos ataques em algumas rainhas, nem tão pouco o fato de uma única operária ser a principal agressora das rainhas.

A metodologia de estudos para as colônias C1 e C2 foi semelhante. O estudo foi direcionado para o comportamento das rainhas e migração da população e não foi observado ataque às rainhas durante o pré-enxameio. $\mathrm{Na}$ colônia C5 a população estava sendo estudada visando outros aspectos da biologia. Havia centenas de indivíduos marcados na população, o pré-enxameio e a eliminação de rainhas ocorreu naturalmente. Durante o pré-enxameio foram observadas 17 operárias marcadas sinalizando para a população migrar, no total realizaram 51 comportamentos de arrastar o abdômen no substrato da entrada do ninho. Elas esfregavam os esternitos gastrais no substrato com rápidos movimentos laterais, como nas demais colônias estudadas. Provavelmente estes indivíduos faziam parte do grupo de escoteiras e recrutadores, pois deixavam o ninho original e voavam em direção ao local do novo ninho. Embora não tenha sido encontrado o agrupamento de escoteiras no novo local do ninho antes da migração, podemos sugerir isso devido aos comportamentos apresentados por elas. Anterior ao pré-enxameio estas operárias foram observadas em atividades ligadas à construção do ninho, interação com adultos, cuidados com a prole e forrageio. 
Tabela 6. Freqüência de atos comportamentais (\%) observados durante a fase de préenxameio na colônia C1 envolvendo as rainhas. Duração: início 25 a 27/02/2000 (tempo cumulativo das observações em vídeo, 9 horas). As siglas utilizadas para descrever os atos comportamentais das rainhas foram descritas no item Material e Métodos (página 18).

\begin{tabular}{cccccccccccc}
\hline Rainhas & PR & AL & CR & RCR & CRO & CCR & RAG & LC & TR & TR-R & $\begin{array}{c}\text { Total } \\
\text { por rainhas }\end{array}$ \\
\hline R1 & 10,26 & 5,88 & 16,22 & 6,06 & 16,39 & 13,33 & 16,00 & 15,63 & 6,67 & 0,00 & 49 \\
R2 & 0,00 & 5,88 & 2,70 & 12,12 & 0,00 & 5,00 & 6,67 & 6,25 & 0,00 & 0,00 & 16 \\
R3 & 12,82 & 0,00 & 10,81 & 9,09 & 9,84 & 5,00 & 6,67 & 3,13 & 0,00 & 0,00 & 27 \\
R6 & 12,82 & 23,53 & 8,11 & 12,12 & 6,56 & 8,33 & 9,33 & 9,38 & 0,00 & 0,00 & 35 \\
R7 & 2,56 & 17,65 & 8,11 & 12,12 & 14,75 & 11,67 & 9,33 & 12,50 & 0,00 & 0,00 & 38 \\
R8 & 17,95 & 5,88 & 13,51 & 9,09 & 8,20 & 10,00 & 13,33 & 9,38 & 0,00 & 0,00 & 40 \\
R10 & 12,82 & 17,65 & 5,41 & 6,06 & 11,48 & 11,67 & 6,67 & 9,38 & 13,33 & 50,00 & 37 \\
R11 & 10,26 & 0,00 & 2,70 & 9,09 & 4,92 & 5,00 & 6,67 & 3,13 & 13,33 & 0,00 & 22 \\
R12 & 12,82 & 0,00 & 0,00 & 6,06 & 3,28 & 0,00 & 9,33 & 18,75 & 46,67 & 0,00 & 29 \\
RB1 & 5,13 & 11,76 & 18,92 & 12,12 & 8,20 & 15,00 & 8,00 & 3,13 & 6,67 & 50,00 & 38 \\
RB2 & 2,56 & 11,76 & 13,51 & 6,06 & 16,39 & 15,00 & 8,00 & 9,38 & 13,33 & 0,00 & 40 \\
Total por & 39 & 17 & 37 & 33 & 61 & 60 & 75 & 32 & 15 & 2 & 371 \\
categoria & 39 & & & & & & & & & & \\
\hline
\end{tabular}

Tabela 7. Freqüência de atos comportamentais (\%) observados durante a fase de préenxameio na colônia C2 envolvendo as rainhas. Duração: início 22 a 25/03/2000 (tempo cumulativo das observações em vídeo, 12 horas). As siglas utilizadas para descrever os atos comportamentais das rainhas foram descritas no item Material e Métodos (página 18).

\begin{tabular}{ccccccccccc}
\hline Rainhas & PR & VR & AL & MA & CR & RCR & CRO & LC & TR & $\begin{array}{c}\text { Total por } \\
\text { rainhas }\end{array}$ \\
\hline R1 & 13,51 & 0,00 & 12,50 & 0,00 & 7,32 & 2,44 & 0,00 & 0,00 & 6,06 & 17 \\
R2 & 20,27 & 0,00 & 12,50 & 0,00 & 21,95 & 14,63 & 15,15 & 14,29 & 9,09 & 45 \\
R4 & 8,11 & 50,00 & 0,00 & 0,00 & 9,76 & 21,95 & 24,24 & 21,43 & 3,03 & 38 \\
R5 & 8,11 & 0,00 & 0,00 & 66,67 & 7,32 & 2,44 & 0,00 & 9,52 & 15,15 & 21 \\
R6 & 10,81 & 0,00 & 12,50 & 0,00 & 17,07 & 9,76 & 12,12 & 0,00 & 21,21 & 31 \\
R7 & 14,86 & 0,00 & 37,50 & 33,33 & 9,76 & 9,76 & 18,18 & 4,76 & 3,03 & 32 \\
R8 & 8,11 & 0,00 & 25,00 & 0,00 & 9,76 & 14,63 & 6,06 & 11,90 & 9,09 & 28 \\
R9 & 4,05 & 0,00 & 0,00 & 0,00 & 4,88 & 9,76 & 15,15 & 19,05 & 12,12 & 26 \\
R10 & 5,41 & 50,00 & 0,00 & 0,00 & 2,44 & 12,20 & 6,06 & 7,14 & 6,06 & 18 \\
R11 & 6,76 & 0,00 & 0,00 & 0,00 & 9,76 & 2,44 & 3,03 & 11,90 & 15,15 & 21 \\
Total & 74 & 2 & 8 & 3 & 41 & 41 & 33 & 42 & 33 & 277 \\
por categoria & 74 & & & & & & & & &
\end{tabular}



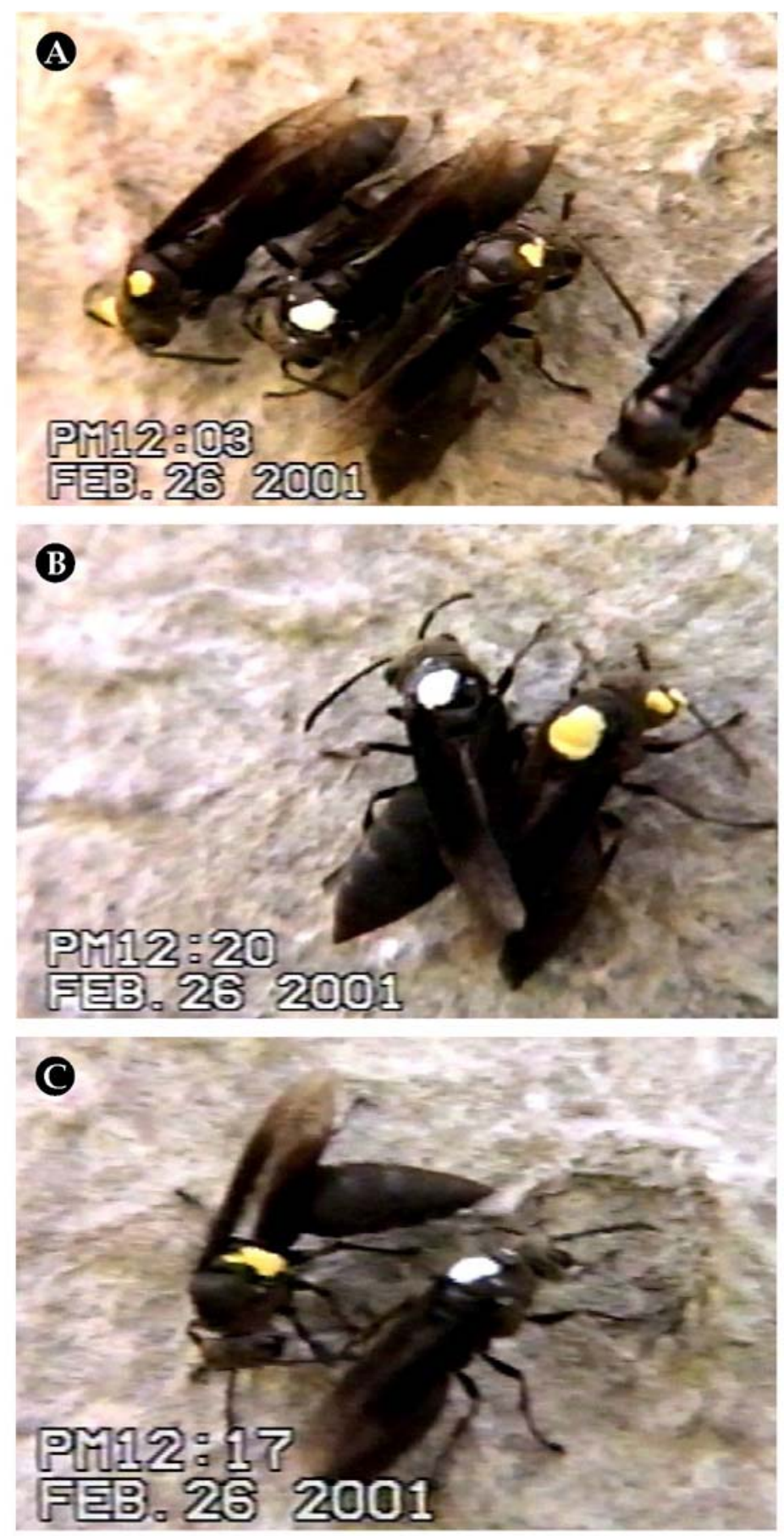

Figura 4. Fase de pré-enxameio, colônia C1: A - rainhas agrupadas; B - rainhas em contato corporal; C - rainha curvando o abdômen para outra rainha. 


\section{C.3.3 - Fase de Estabelecimento das colônias C1, C2, C3 e C5.}

\section{C.3.3.1 - Comportamento das rainhas da colônia C1 durante o estabelecimento.}

O estabelecimento da colônia iniciou-se com a chegada da população ao LNN e imediata construção de favos e invólucro. As operárias iniciaram simultaneamente a construção de três pedúnculos e do invólucro no ápice do agrupamento. Os favos foram construídos onde as escoteiras depositaram veneno no substrato durante o pré-enxameio. A população espalhou-se por 50 cm abaixo do local marcado, aparentemente formando uma linha de defesa contra possíveis predadores.

Ao atingir o local do novo ninho usando o caminho químico feito por escoteiras, as rainhas fizeram o reconhecimento do local, tocando o substrato com as antenas e aparelho bucal e realizando contato bucal com operárias. As rainhas ficaram próximas do local de construção dos pedúnculos e tocavam com as mandíbulas o material vegetal ainda úmido. Assim que as bases das primeiras células ficaram prontas, as rainhas subiam nas células e inspecionavam o interior das mesmas com as mandíbulas e antenas.

Trinta minutos após a chegada da população já havia uma célula pronta e a base de 3 favos sendo construídos abaixo do primeiro, seguindo a mesma orientação do primeiro e mantendo a mesma distância entre eles. As rainhas inspecionavam constantemente os favos desde o início de sua construção. Elas circulavam entre as construtoras inspecionando as novas células e tentando botar. As posturas das rainhas iniciaram assim que as primeiras células tomaram forma.

As construtoras trabalharam rapidamente na construção de células e do invólucro, pois a rápida construção certamente garante a proteção da população e dos ovos depositados nas células. Com a rápida incorporação de material vegetal úmido nos novos favos as construtoras ficavam sobre as células vibrando intensamente as asas para remover o excesso de água pois, sem isso, o 
material vegetal ainda muito úmido não permitiria a moldagem adequada necessária para prosseguir a construção das células. Desta forma, as construtoras às vezes impediam a aproximação das rainhas. Porém, foram observadas posturas em células onde o material de construção ainda estava úmido.

Com o aumento do número de células, algumas operárias que foram escoteiras inseriram o abdômen nas células provavelmente tentando realizar postura sem sucesso. Estes indivíduos não apresentavam síndrome comportamental de rainhas. Introduziam o abdômen nas células novas por alguns instantes e depois voltavam a trabalhar na construção das mesmas. Não foi observada postura de intermediárias nesta colônia. A Tabela 8 apresenta os principais atos comportamentais realizados pelas rainhas da colônia C1 durante o estabelecimento.

Todas as rainhas realizaram atos comportamentais ligados à postura, no entanto, não houve diferença estatisticamente significante entre elas em relação ao número destes atos comportamentais (One Way ANOVA, $\mathrm{p}=0,596$ ). Os atos comportamentais relacionados com as interações com adultos foram abundantes. As rainhas curvaram o abdômen umas para as outras e para as operárias. O alto número deste comportamento está ligado ao fato de as rainhas estarem se locomovendo entre os favos em construção em busca de células para botar. As rainhas também ficaram próximas umas das outras no ápice do agrupamento e também em contato corporal (Tabela 8). Os atos comportamentais ligados as interações competitivas entre as rainhas foram evidentes, houve competição por células para realizar postura entre as rainhas que patrulhavam os favos e faziam inspeção nas células. Foram observadas rainhas sendo retiradas de célula por outra rainha quando já estavam com o abdômen inserido na célula e se posicionando para botar. Outra rainha se aproximava e mordiscava-lhe o abdômen ou as pernas forçando a rainha a deixar a célula. Em seguida, ela fazia inspeção na célula e realizava a postura, ou abandonava a célula (Tabela 8). Após a postura as rainhas invariavelmente viravam-se para a célula com o ovo recém botado e com o aparelho bucal 
fixavam o ovo e, também, tocavam o interior da célula, provavelmente, deixando sua marca química, e sinalizando para outras rainhas. Contudo nesta fase não foi observado oofagia.

O comportamento de fixar o ovo foi amplamente realizado pelas rainhas do ninho (Tabela 8). Mesmo em ovos botados por outras rainhas, outras rainhas que estavam próximas da célula antecipavam-se à rainha que havia botado e faziam a fixação do ovo. A rainha que botou esperava a rainha intrusa terminar ou mordiscava seu abdômen, ou a empurrava com a cabeça na tentativa de retirá-la da célula. Este comportamento sugere a proteção dos ovos das rainhas na fase inicial do ninho uma vez que a "intenção" da população é produzir o mais rápido possível uma nova geração. Não foi observado oofagia pelas rainhas nesta fase da colônia.

\section{C.3.3.2 - Postura das rainhas durante o estabelecimento da colônia C1.}

O comportamento ritualizado de postura das rainhas de $P$. fraternus é similar ao de rainhas de outros Epiponini, Agelaia (=Stelopolybia) pallipes (Simões, 1977), Pr. acutiscutis (Naumann, 1970), e também de Chartergellus communis, Parachartergus smithii, Synoeca cyanea e Pseudopolybia vespiceps (obs. pessoal).

Em $P$. fraternus a postura é invariavelmente precedida de inspeção na célula a ser botada. A rainha aproximava-se da célula, tocava seu interior com as antenas por alguns segundos e em seguida introduzia o abdômen na célula, tocando o fundo da mesma com a parte distal do abdômen. Depois de posicionada ela ficava imóvel e antes de realizar a postura fazia movimentos de

contração no abdômen. A exposição do ferrão precede a saída do ovo. Após a postura, ela se vira e começa a fixar o ovo com lambidas no interior da célula.

Durante o estabelecimento da colônia C1 as rainhas realizaram 68 posturas. Destas, 31 tiveram seu tempo de duração medido (56,33 \pm 16,41 seg.). Não houve diferença significativa entre a duração das posturas das rainhas 
(One Way ANOVA, $\mathrm{p}=0,81$ ). Foram medidas também as durações de 22 inspeções de células $(15,77 \pm 6,28$ seg.), e a duração do comportamento de fixar o ovo após postura $\left(30,31 \pm 10,13\right.$ seg., $\left.\mathrm{n}^{\mathrm{o}}=42\right)$. Quanto à fixação do ovo após a postura, em alguns casos foi observado maior variação no tempo devido à competição entre as rainhas para realizar a fixação do ovo. A rápida construção de células e do invólucro se deve a um pequeno número de vespas construtoras e forrageadoras, a maior parte da população permaneceu completamente inativa nesta fase. É provável que na colônia houvesse um grande número de indivíduos jovens.

\section{C.3.3.3 - Comportamentos das rainhas durante o estabelecimento da colônia C2.}

A migração durou aproximadamente 25 minutos e a construção de favos e invólucro iniciou-se imediatamente após a chegada da população. Antes da migração foram observadas escoteiras removendo polpa vegetal do ninho original.

Durante o pré-enxameio foram observadas 10 rainhas no ninho original, apenas 8 chegaram ao local do novo ninho. Semelhante ao observado na colônia $\mathrm{C} 1$, assim que pousaram, as rainhas tocaram o substrato com as antenas e aparelho bucal e fizeram contato bucal com algumas operárias. A Tabela 10 relaciona os principais atos comportamentais das rainhas observados por 4 horas durante o estabelecimento. As rainhas fizeram muitas inspeções nas células novas. Durante a construção dos favos ficaram próximas e tocavam o material vegetal com as mandíbulas. Às vezes, posicionavam-se para botar mas eram impedidas por outra rainha ou pelas construtoras que trabalhavam na célula. Como foi observado durante o pré-enxameio e citado anteriormente, as rainhas não ficavam agrupadas ou em contato corporal. Foram observados poucos atos de curvar o abdômen entre as rainhas. Foi observada uma discreta competição por célula para realização de postura. Durante o estabelecimento, foram observadas duas posturas feitas pela mesma rainha. 


\section{C.3.3.4 - Estabelecimento da colônia C3.}

O repertório comportamental das rainhas no LNN não diferiu qualitativamente das demais colônias estudadas. As rainhas permaneceram no ápice do ninho, em grupos ou isoladas, curvando o abdômen em direção a outras rainhas e operárias, sempre visitando a área de construção de células onde havia intermediárias competindo por células para fazer posturas.

Na colônia C3 os atos comportamentais de rainhas e de intermediárias não foram quantificados. A primeira postura nesta colônia foi feita por uma intermediária que foi escoteira durante o pré-enxameio. Este fato foi similar à colônia C5 onde as intermediárias foram ativas durante o estabelecimento, e diferente das colônias C1 e C2 onde não foram observadas intermediárias realizando posturas.

\section{C.3.3.5 - Comportamento das intermediárias durante o estabelecimento da colônia C3.}

Na fase inicial do estabelecimento da colônia C3 foram observadas várias intermediárias realizando posturas. Estas fêmeas não apresentavam síndrome comportamental de rainha e competiam com as rainhas por células para realizar postura. O comportamento das intermediárias não diferiu do observado na colônia C5. Várias delas ficavam ao redor das células tentando realizar postura, faziam inspeção, introduziam o abdômen, faziam postura e, às vezes, eram impedidas por outro indivíduo que as tocava com antenas e mordiscava o abdômen quando inserido na célula.

Não foi observado nenhum caso de oofagia, mas é provável que tenham ocorrido devido à competição observada, principalmente, entre as intermediárias, por célula vazia.

A flexibilidade na divisão de trabalho foi confirmada em um indivíduo que durante o pré-enxameio foi escoteira, identificada no local do novo ninho foi vista enquanto depositava veneno no substrato antes da migração da população. Durante o estabelecimento realizou postura na primeira célula de um favo novo (Fig. 5 A e B). Esta escoteira foi coletada, e a dissecação mostrou 
que tinha ovários desenvolvidos com dois ovócitos maturos e os apódemas dos esternitos gastrais bem pigmentados (Mateus et al., 2004). Outras escoteiras permaneceram no ninho construindo favos e invólucro até o dia da coleta da população.

\section{C.3.3.6 - Eliminação de rainhas durante o estabelecimento da colônia C3.}

A principal eliminadora de rainhas fez parte do grupo de escoteiras. Esta fêmea foi marcada no tórax no LNN enquanto esfregava o abdômen no substrato e depositava veneno. Após a chegada da população no LNN foi observada comportando-se pacificamente entre os membros da colônia.

O primeiro ataque a uma rainha ocorreu 4 horas após a chegada da população no LNN onde já havia alguns favos e células com ovos. A agressora aproximava-se das rainhas que ficavam em grupos ou isoladas. Tocava um indivíduo com as antenas e se afastava, ou atacava imediatamente prendendo a vítima principalmente pelas asas. Algumas rainhas conseguiam fugir antes de serem atacadas ou após a investida sobre elas, outras ficavam presas por alguns instantes e muitas vezes as duas caíam no chão (Fig. 6 A e B). Esta fêmea agressora foi observada patrulhando toda região do ninho, inclusive fora dos limites do invólucro onde havia indivíduos refugiados. Na Tabela 11 estão relacionadas as rainhas que foram coletadas fora do ninho após sucessivos ataques. Essas ficavam refugiadas próximo do ninho, ou caídas no chão embaixo do ninho, sendo presa fácil de predadores.

Os ataques foram direcionados somente as rainhas. Curiosamente, no ninho havia dezenas de intermediárias realizando posturas e não foram atacadas. Na colônia C5 também ocorreu eliminação de rainhas, elas foram atacadas e eliminadas durante o pré-enxameio inicialmente por uma operária e, posteriormente, por operárias e uma rainha que participou da eliminação de outras rainhas.

As intermediárias observadas na colônia C5 durante o estabelecimento também não foram atacadas. Os ataques às rainhas da colônia C3 começaram repentinamente e não foi possível identificar a causa. Entre um ataque e outro, a agressora foi observada realizando diversas tarefas tais como a construção de 
invólucro, macerar e dividir polpa, fixar ovo, realizar vários contatos bucais com operárias e inspecionar células (Fig. 6 C e D). Foram observados inúmeros ataques, mas em alguns a agressora não obteve sucesso. Vários indivíduos não ficavam submissos à agressora, uma rainha ficou de frente com a agressora e colocou o primeiro par de pernas sobre seu corpo, mordiscou seu tórax e o vértice, a agressora fugiu imediatamente. Da mesma forma a agressora ficou submissa a uma escoteira.

A agressora foi coletada e dissecada e observou-se que ela não estava inseminada, tinha ovário pouco desenvolvido e não era jovem (Tabela 12). Não se pode determinar as causas dos sucessivos ataques às rainhas.

\section{C.3.3.7 - Coleta de rainhas e intermediárias em postura na colônia C3.}

Um dos objetivos de estudo na colônia C3 era testar a substituição de rainhas, removendo todas as poedeiras, e também estudar os comportamentos das operárias durante a orfandade. Por isso, após a coleta da fêmea agressora de rainhas, foram também coletadas intermediárias e rainhas restantes no ninho. Foram coletadas durante a realização de postura. O objetivo era deixar a colônia órfã. Na Tabela 13 estão os dados referentes a esses indivíduos.

Na colônia que estava produzindo machos e provavelmente rainhas, havia um número elevado de intermediárias. Após a remoção da maioria de rainhas e intermediárias da colônia, outro comportamento foi observado entre os membros da população, os indivíduos eram seguros por uma ou mais fêmeas que subiam em seu corpo e com movimentos rítmicos mordiscavamlhes a cabeça, tórax, pernas e asas. O indivíduo agredido raramente fugia. Em alguns casos foi observado que o agredido exibia uma gota em sinal de subordinação. Em alguns casos este comportamento desencadeou violentas lutas onde ambas caíam do ninho. Este comportamento foi observado no substrato onde sempre havia pequenos grupos de vespas paradas.

Foram coletadas algumas fêmeas enquanto mordiscavam o corpo de outros indivíduos. Estes indivíduos foram dissecados e a Tabela 12 mostra o padrão de ovário e idade relativa de cada indivíduo coletado. Apesar desta 
nova fase de comportamento na colônia, as intermediárias continuaram a fazer posturas. Várias foram impedidas, temporariamente, enquanto estavam com o abdômen dentro da célula ou fazendo inspeção antes das posturas. Estas eram seguras por uma ou mais fêmeas que começavam a mordiscar seu corpo, impedindo a postura. Este comportamento foi observado com maior freqüência no ápice do ninho onde havia dezenas de indivíduos inativos, provavelmente jovens. Na colônia C5, também foi observado o mesmo comportamento após a eliminação de algumas rainhas, ocorria principalmente onde havia pequenos grupos de vespas paradas e também nos favos.

\section{C.3.3.8 - Comportamento das rainhas e intermediárias durante o estabelecimento da colônia C5.}

Em 17/06/03 no início do estabelecimento havia 5 rainhas na população. As demais identificadas e observadas anteriormente foram eliminadas durante o pré-enxameio. No início do estabelecimento não foram observados atos agressivos entre as rainhas, ou entre rainhas e intermediárias, ou operárias atacando rainhas ou intermediárias. A Tabela 14 apresenta os principais atos comportamentais de rainhas durante o estabelecimento da colônia C5. Todas as rainhas realizaram atos comportamentais ligados a postura, e também estiveram envolvidas em interações competitivas. Fizeram diversos contatos bucais com operárias, estiveram agrupadas e com os corpos encostados como observado nas colônias C1 e C2 e inseriram o abdômen em células sem realizar postura.

Durante o estabelecimento foram medidas as durações de 12 posturas das rainhas, sendo 8 da rainha R3VD. Não houve diferença significativa nas durações das posturas das rainhas (t-test, $\mathrm{p}=0,73)$. Foram comparadas as durações de 8 posturas da rainha R3VD com 6 posturas de intermediárias, não houve diferença significativa nas durações das posturas (t-test, $p=0,77$ ). As durações de 6 posturas de intermediárias foram comparadas com 4 posturas das demais rainhas, não houve diferença significante nas durações das posturas 
(t-test, $p=0,63)$. Também foram medidas as durações de 10 comportamentos de fixação de ovos feitas por rainhas após a postura $(33,1 \pm 12,71$ seg.), e de 6 inspeções de células antes da postura $(24,83 \pm 29,30$ seg.). A Tabela 15 mostra a duração em segundos das posturas das rainhas e intermediárias durante o estabelecimento. No entanto não foi observada dominância da rainha R3VD sobre as demais rainhas nos atos comportamentais ligados a postura ou as interações competitivas (Kruskal-Wallis One Way, $\mathrm{p}=0,344$ ).

Durante o pré-enxameio ela não foi agredida, enquanto que as outras rainhas presentes na colônia, sofreram agressões de operárias e algumas foram eliminadas. Devido ao reduzido número de células, foi observada uma certa competição por células vazias entre as rainhas. Enquanto tentavam realizar posturas eram retiradas da célula, ou retiravam outra rainha, mordiscando o abdômen e pernas, ou empurrando com a cabeça. As rainhas também competiram para a fixação dos ovos nas células, independente de quem botou.

A Tabela 16 apresenta os principais atos comportamentais realizados pelas intermediárias durante o estabelecimento. Com o início da construção das células, algumas intermediárias passaram a fazer inspeção de célula, realizar posturas, fixar ovos e realizar oofagia entre outros comportamentos competitivos na presença das rainhas (Fig. 7 A e B). Ficou evidente a competição por célula entre as rainhas e entre rainhas e intermediárias para realizar postura. Não ficou caracterizado dominância de alguma rainha ou de alguma intermediária durante este período. As interações observadas entre rainhas e intermediárias estavam sempre relacionadas à postura e ocorreram principalmente em volta do favo. Rainhas ou intermediárias foram retiradas da célula enquanto faziam, ou quando estavam com o abdômen inserido na célula para realizar postura, outra rainha ou intermediária se aproximava, empurrava com a cabeça ou mordiscava o abdômen e tarsos, até que esta deixasse a célula.

O comportamento de postura das intermediárias foi semelhante as das rainhas. Era precedido de inspeção de célula e durante a postura o posicionamento na célula foi semelhante ao de rainhas. Quando terminavam a postura voltavam-se para a célula e tocavam o ovo quando não eram impedidas 
por outra intermediária ou rainha. Durante o estabelecimento foram medidas as durações de 6 posturas de intermediárias, a duração média foi de 77,2 $\pm 24,48$ seg., e as durações de 12 posturas de rainhas, a média foi de $80.83 \pm 24,50$ seg. (Tabela 15).

Foram observadas oofagia entre intermediárias e de intermediárias em ovos de rainhas (Tabela 16). O comportamento foi semelhante nas duas situações, a intermediária aproximava se da célula onde uma rainha ou intermediária estava fixando o ovo após a postura, mordiscavam ou empurravam com a cabeça retirando da célula quem geralmente havia botado. Em seguida comia o ovo. Após a oofagia, às vezes, inseriam o abdômen na célula tentando botar. Foram contadas 7 oofagias de intermediárias em ovos de rainhas e 3 em ovos de intermediárias. Devido ao reduzido número de células e à pouca altura desta, foi possível ter certeza do comportamento. Devido à competição entre rainhas e intermediárias observada nesta fase da colônia é possível que tenham ocorrido outros casos de oofagia. Após a postura as rainhas fixavam o ovo e deixavam a célula. Algumas intermediárias após a postura, quando não eram retiradas da célula, ficavam na frente destas provavelmente protegendo o ovo por até 20 minutos, mas este comportamento não impedia a oofagia por uma outra intermediária. Fato interessante foi que as intermediárias comeram ovos de rainhas. A explicação é que estas intermediárias estariam na transição intermediária-rainha. Com a eliminação e redução no número de rainhas na colônia elas estariam assumindo o "status" de rainhas antes mesmo de serem inseminadas.

Outro comportamento relevante foi o fato das intermediárias fazerem a fixação de ovos nas células, independente de quem botou. Em colônias de $P a$. smithii na fase de estabelecimento foi constatado que os ovos botados por intermediárias são comidos por rainhas (S. Mateus não publ.). Provavelmente, estes ovos seriam fonte de proteína para as rainhas, à semelhança do que ocorre em Meliponini. Não foi constatada nenhuma oofagia feita por rainhas. No entanto, não se pode descartar esta possibilidade, pois em outras colônias estudadas foi verificada oofagia de rainhas em ovos de rainhas, durante o processo de redução de rainhas na colônia. 


\section{C.3.3.9 - Sobre a identidade das intermediárias da colônia C5.}

Pouco se sabe sobre o papel das intermediárias nas colônias de vespas sociais da tribo Epiponini. Nos gêneros e espécies onde existe baixa diferenciação entre as castas elas estão quase sempre presentes. Foram poucos os estudos mostrando que as intermediárias além de botar ovos não funcionais, realizam outras funções de grande importância dentro da colônia (Simões, 1977; Simões \& Zucchi, 1980).

Nesta colônia as intermediárias foram construtoras e forrageadoras. Algumas intermediárias foram coletadas logo após a realização de postura para a verificação do padrão de desenvolvimento ovariano, inseminação, número de ovócitos e idade relativa (Tabela 17). As intermediárias coletadas não eram jovens, tinham ovócitos maturos nos ovários e não estavam inseminadas. As intermediárias coletadas foram marcadas em datas diferentes. A idade mínima aferida pela marcação foi de 54 dias e a máxima de 78 dias. É possível que estes indivíduos estivessem com os ovários desenvolvidos antes da migração da população. Outras intermediárias presentes na colônia não foram coletadas propositalmente. Estas permaneceram no ninho mantendo o mesmo padrão de comportamento.

Nesta fase as intermediárias não foram observadas realizando funções de construtoras ou de forrageadoras como foi observado na fase de produção de operárias da colônia. Na Tabela 16 estão relacionadas os principais atos comportamentais realizados pelas intermediárias durante o início do estabelecimento. Pode-se verificar que as atividades das intermediárias estiveram diretamente relacionadas com a postura. Foram observadas fazendo inspeção de célula, realizando posturas, retirando rainhas ou intermediárias das células enquanto tentavam botar, ou quando fixavam ovos.

\section{C.3.3.10 - Eliminação de rainhas durante o estabelecimento e o comportamento das intermediárias da colônia C5.}

A eliminação de rainhas em vespas sociais é um fenômeno pouco conhecido. Estudos realizados em cinco colônias de P. fraternus coletadas em 
diferentes épocas do ano revelaram que existe uma variação no número de rainhas na colônia, assim como no número de intermediárias (Mateus et al., 2004). Entretanto, as causas da eliminação de rainhas são completamente desconhecidas. Alguns autores observaram indiretamente o desaparecimento ou a eliminação de rainhas em colônias que estavam sendo estudadas, mas a eliminação direta e como ela ocorre são fatos desconhecidos.

Em Meliponini estudos revelaram a participação direta de rainha virgem na eliminação da rainha fisiogástrica (Nogueira-Ferreira, não publ.), bem como a participação de uma virgem na eliminação de outras virgens (da Silva et al., 1972). Em P. fraternus este fenômeno foi constatado em duas colônias. A eliminação de rainhas ocorreu tanto durante o pré enxameio, como durante o estabelecimento da colônia C5. Na colônia C3 o evento ocorreu durante o estabelecimento e nas colônias C1 e C2, a eliminação das rainhas foi gradual, tendo ocorrido ao longo do ciclo da colônia.

Na colônia C5 a eliminação de rainhas iniciou-se durante o préenxameio. A população migrou em 17/06/03. No início do estabelecimento no LNN havia 5 rainhas na colônia. A interação entre elas e as operárias era pacífica, todas elas realizaram atos comportamentais ligados à reprodução e, também, estiveram envolvidas em interações competitivas (Tabela 14). Não foram observados atos agressivos ou ataques às rainhas. Em 23/06/03, uma das rainhas presente no ninho (R3VD) apresentou comportamento diferente do observado no dia anterior. Ela se locomovia rapidamente por todo o ninho, passando sobre as operárias que estavam paradas sob o invólucro e favo, mordiscando o ápice da cabeça e o tórax, ou colocando as pernas dianteiras sobre as operárias e tocava com as antenas numa espécie de reconhecimento. Podia, inclusive, percorrer toda a extensão do galho onde estava localizado o ninho, vibrando intensamente as asas. Foram observados muitos contatos bucais sendo iniciados pela rainha. Estes contatos bucais foram diferentes dos observados anteriormente, eram mais agressivos por parte da rainha que prendia a operária com as pernas dianteiras forçando-as a fazer o contato bucal. No geral, ela parecia estar reconhecendo cada indivíduo da colônia (Fig. 7 C e D). Foram observados alguns casos em que a rainha foi agressiva em relação às operárias, mordiscando na cabeça tanto sobre o favo como sobre o invólucro. 
Nesses casos, a operária imediatamente expunha uma gota entre as mandíbulas em sinal de submissão.

Com a mudança repentina de comportamento da rainha $\mathrm{R} 3 \mathrm{VD}$, as demais rainhas que estavam no ninho (R3BR, R3AM, RG30, ROE) não foram mais observadas junto no ninho. Elas passaram a receber agressões de operárias e também da própria rainha e refugiaram-se nas folhas da árvore nas proximidades do ninho. Em 23/06/03 a rainha R3AM que estava refugiada em folhas nas proximidades do ninho, tentou pousar no ninho e foi atacada por operárias, fugindo imediatamente. Após isso, novamente pousou no agrupamento e foi atacada e segura pelas asas por várias operárias. A rainha R3VD participou diretamente da agressão mordendo a base das asas da rainha. Quando conseguiu escapar das agressões a R3AM estava com a asa direita cortada na base, impossibilitada de voar, tendo caído dentro do saco coletor de lixo embaixo do ninho. As rainhas RG30 e ROE também foram atacadas por operárias quando tentavam retornar ao ninho. Como só ficavam refugiadas nas proximidades do ninho, posteriormente foram coletadas para análise (Tabela 18). A rainha R3BR não foi mais observada no ninho ou nas proximidades desde que a rainha R3VD mudou de comportamento. Possivelmente, foi eliminada. A R3VD iniciou agressão em uma operária que estava parada sob o invólucro depois de tocá-la com as antenas, mordeu sua asa direita e arrastou-a entre as demais vespas do ninho. A seguir algumas operárias participaram da agressão. Esta vespa foi coletada posteriormente no saco coletor de lixo com uma das asas arrancadas. Era um indivíduo jovem sem desenvolvimento ovariano. È importante ressaltar que as intermediárias presentes no ninho não sofreram agressões de operárias ou da rainha (R3VD). O número de atos comportamentais realizados pelas intermediárias durante o período da eliminação de rainhas foi baixo, devido ao fato de ficarem afastadas do favo, realizaram poucas inspeção de células e contatos bucais. Foram mordiscadas por operárias e foram observadas isoladas sob o invólucro afastadas do favo. Foram observados alguns encontros entre a rainha R3VD e as intermediárias no invólucro e nas proximidades do favo, não houve agressão física por parte da rainha. Porém, após o reconhecimento de uma das intermediárias (94L) que 
estava parada sob o invólucro, a rainha andou ao lado da intermediária vibrando as asas intensamente fazendo-a afastar-se do local.

A mudança repentina de comportamento da rainha R3VD desencadeou um outro comportamento não observado anteriormente entre os membros da colônia. Algumas operárias passaram a mordiscar outras operárias sob o invólucro e nas proximidades do favo. Uma ou mais operária aproximava-se de outra ou de uma intermediária, e mordiscava o seu corpo e asas com movimentos rítmicos. O indivíduo que estava sendo mordiscado ficava submisso. Às vezes ele abria as mandíbulas e expunha uma gota. Este comportamento teve duração variável. Raramente os indivíduos que estavam sendo mordiscados conseguiam fugir. Entre as operárias este comportamento não foi exclusivo e direcionado para alguns indivíduos. O comportamento foi recíproco, os indivíduos que faziam o comportamento também o recebiam, a exceção foram operárias mordiscando as intermediárias, as quais não foram observadas realizando este comportamento.

O comportamento descrito difere de limpeza corporal. O mesmo comportamento das operárias também foi observado na colônia C3 após a eliminação de algumas rainhas durante o estabelecimento (item, Eliminação de rainhas na colônia C3, este trabalho).

Este comportamento provavelmente está relacionado com o grande número de indivíduos inativos na colônia, pois coincidiu com um período de baixa atividade de construção e forrageio. Aparentemente ele não se relaciona com controle de posturas, pois havia algumas intermediárias ativas no ninho e apenas uma rainha. Em outra população estudada observou-se o mesmo fenômeno. A rainha também mordiscou rapidamente algumas operárias durante o patrulhamento no ninho. Possivelmente este comportamento da rainha está ligado à fase da colônia e ao reconhecimento dos indivíduos. Normalmente as rainhas não fazem este comportamento e apenas procuram contato bucal com as operárias.

Nossos resultados estão parcialmente de acordo com a afirmação de West-Eberhard (1978b), pois nas colônias C1 e C2 foi observada a diminuição gradativa das rainhas, fenômeno este que a autora chamou de oligogenia cíclica. Nas colônias C3 e C5 a eliminação das rainhas foi abrupta, 
possivelmente pode haver relação com o alto número de intermediárias ou produção de novas rainhas e também com o grau de parentesco entre rainhas e entre rainhas e operárias. 
Tabela 8. Freqüência de atos comportamentais (\%) observados durante a fase de estabelecimento na colônia C1 envolvendo as rainhas. Duração: de 27 a 28/01/2001 (tempo cumulativo das observações em vídeo $=11$ horas). As siglas utilizadas para descrever os atos comportamentais das rainhas foram descritas no item Material e Métodos (página 18).

\begin{tabular}{|c|c|c|c|c|c|c|c|c|c|c|c|c|c|c|c|c|c|c|}
\hline Rainhas & IC & PO & FXO & PR & $\mathrm{AL}$ & CR & RCR & CRO & CCR & RAG & LC & TR & $\mathbf{R R}$ & RT & RRFX & RTFX & TP & $\begin{array}{l}\text { Total de } \\
\text { atos por } \\
\text { rainhas } \\
\end{array}$ \\
\hline $\mathrm{R} 1$ & 10,84 & 13,24 & 11,76 & 19,35 & 10,00 & 6,61 & 4,92 & 8,06 & 6,49 & 9,09 & 12,35 & 7,14 & 9,52 & 4,76 & 0,00 & 0,00 & 7,69 & 99 \\
\hline $\mathrm{R} 2$ & 15,06 & 8,82 & 9,24 & 16,13 & 20,00 & 7,44 & 11,48 & 8,06 & 6,49 & 9,09 & 2,47 & 7,14 & 9,52 & 23,81 & 9,09 & 18,18 & 15,38 & 111 \\
\hline $\mathrm{R} 3$ & 9,04 & 8,82 & 7,56 & 6,45 & 0,00 & 8,26 & 10,66 & 4,84 & 3,90 & 7,27 & 6,17 & 7,14 & 0,00 & 0,00 & 0,00 & 9,09 & 15,38 & 77 \\
\hline R6 & 6,63 & 16,18 & 12,61 & 19,35 & 16,67 & 16,53 & 11,48 & 11,29 & 8,44 & 14,55 & 6,17 & 0,00 & 4,76 & 23,81 & 18,18 & 9,09 & 0,00 & 124 \\
\hline R7 & 6,02 & 7,35 & 6,72 & 9,68 & 10,00 & 4,13 & 6,56 & 8,06 & 1,95 & 3,64 & 11,11 & 0,00 & 9,52 & 4,76 & 0,00 & 0,00 & 0,00 & 64 \\
\hline R8 & 12,65 & 8,82 & 10,08 & 12,90 & 13,33 & 9,92 & 10,66 & 8,06 & 8,44 & 7,27 & 9,88 & 28,57 & 14,29 & 19,05 & 27,27 & 9,09 & 7,69 & 118 \\
\hline R10 & 7,83 & 7,35 & 10,08 & 3,23 & 0,00 & 5,79 & 7,38 & 6,45 & 7,79 & 7,27 & 13,58 & 7,14 & 0,00 & 9,52 & 27,27 & 18,18 & 7,69 & 87 \\
\hline R11 & 4,22 & 4,41 & 4,20 & 6,45 & 13,33 & 7,44 & 13,11 & 16,13 & 8,44 & 10,91 & 9,88 & 0,00 & 4,76 & 0,00 & 0,00 & 9,09 & 0,00 & 85 \\
\hline R12 & 10,24 & 10,29 & 11,76 & 3,23 & 3,33 & 8,26 & 4,10 & 6,45 & 5,19 & 1,82 & 13,58 & 7,14 & 23,81 & 0,00 & 18,18 & 0,00 & 46,15 & 93 \\
\hline RB1 & 7,83 & 7,35 & 7,56 & 3,23 & 6,67 & 14,05 & 10,66 & 8,06 & 26,62 & 18,18 & 8,64 & 14,29 & 4,76 & 9,52 & 0,00 & 9,09 & 0,00 & 129 \\
\hline RB2 & 9,64 & 7,35 & 8,40 & 0,00 & 6,67 & 11,57 & 9,02 & 14,52 & 16,23 & 10,91 & 6,17 & 21,43 & 19,05 & 4,76 & 0,00 & 18,18 & 0,00 & 113 \\
\hline $\begin{array}{l}\text { Total por } \\
\text { categoria }\end{array}$ & 166 & 68 & 119 & 31 & 30 & 121 & 122 & 62 & 154 & 55 & 81 & 14 & 21 & 21 & 11 & 11 & 13 & 1100 \\
\hline
\end{tabular}

Tabela 9. Duração das posturas realizadas por cada rainha da colônia C1 durante o estabelecimento. Duração: de 27 a 28/01/2001 (tempo cumulativo das observações em vídeo $=11$ horas).

\begin{tabular}{ccccc}
\hline Rainhas & $\begin{array}{c}\text { Número de posturas por } \\
\text { rainhas }\end{array}$ & $\begin{array}{c}\text { Duração mínima em } \\
\text { segundos }\end{array}$ & $\begin{array}{c}\text { Duração máxima em } \\
\text { segundos }\end{array}$ & Média \pm DP \\
\hline R1 & 2 & 41 & 49 & $45 \pm 5,65$ \\
R2 & 2 & 45 & 64 & $54,5 \pm 13,43$ \\
R3 & 3 & 37 & 100 & $65,33 \pm 31,97$ \\
R6 & 4 & 42 & 52 & $46 \pm 4,54$ \\
R7 & 2 & 45 & 52 & $48,5 \pm 4,94$ \\
R8 & 3 & 40 & 62 & $52 \pm 11,13$ \\
R11 & 8 & 37 & 101 & $61,62 \pm 20,01$ \\
R12 & 4 & 47 & 91 & $60,25 \pm 20,61$ \\
RB1 & 3 & 42 & 63 & $56 \pm 12,12$ \\
- & 31 & 41,78 & 70,44 & - \\
\hline
\end{tabular}


Tabela 10. Freqüência de atos comportamentais (\%) observados durante a fase de estabelecimento na colônia C2 envolvendo as rainhas. Duração: em 24/03/01 (tempo cumulativo das observações em vídeo, 4 horas). As siglas utilizadas para descrever os atos comportamentais das rainhas foram descritas no item Material e Métodos (página 18).

\begin{tabular}{|c|c|c|c|c|c|c|c|c|c|c|c|c|c|c|}
\hline Rainhas & IC & PO & FXO & TPO & CR & RCR & CRO & LC & TR & TR-R & TP & $\mathbf{R R}$ & RT & $\begin{array}{c}\text { Total por } \\
\text { rainhas }\end{array}$ \\
\hline $\mathrm{R} 2$ & 14,29 & - & - & 14,29 & - & - & - & 9,09 & 25,00 & - & 57,14 & - & - & 13 \\
\hline $\mathrm{R} 4$ & 9,52 & - & - & 9,52 & - & 100,00 & - & 9,09 & 37,50 & - & 28,57 & - & - & 12 \\
\hline R5 & 28,57 & - & - & 9,52 & - & - & 50,00 & 27,27 & 37,50 & 100,00 & - & 100,00 & - & 17 \\
\hline R6 & 4,76 & - & - & 4,76 & - & - & 50,00 & 18,18 & - & - & - & - & 100,00 & 6 \\
\hline R7 & 4,76 & - & 25,00 & 14,29 & - & - & - & 18,18 & - & - & 14,29 & - & - & 8 \\
\hline R8 & 19,05 & - & 25,00 & 23,81 & - & - & - & 9,09 & - & - & - & - & - & 11 \\
\hline R9 & 19,05 & 100,00 & 50,00 & 23,81 & 100,00 & - & - & 9,09 & - & - & - & - & - & 15 \\
\hline $\begin{array}{l}\text { Total por } \\
\text { categoria }\end{array}$ & 21 & 2 & 4 & 21 & 1 & 2 & 2 & 11 & 8 & 1 & 7 & 1 & 1 & 82 \\
\hline
\end{tabular}

Tabela 11. Rainhas da colônia C3 coletadas no chão ou refugiadas fora do ninho após ataque da operária agressora durante o estabelecimento. Duração: de 05 a 06/03/2003 (tempo cumulativo das observações em vídeo, 12 horas). O sinal + indica fêmea inseminada. Padrão de ovário de 1 a 5 e idade relativa de 1 a 4, cf. Mateus et al., (2004).

\begin{tabular}{|c|c|c|c|c|c|c|c|c|c|c|c|c|c|}
\hline \multirow{2}{*}{ Data } & \multirow{2}{*}{ Quantidade } & \multicolumn{5}{|c|}{ Padrão de ovário } & \multicolumn{2}{|c|}{ Inseminação } & \multicolumn{4}{|c|}{ Idade Relativa } & \multirow{2}{*}{ Observações } \\
\hline & & 1 & 2 & 3 & 4 & 5 & + & - & 1 & 2 & 3 & 4 & \\
\hline $05 / 03 / 03$ & 3 & $=$ & $=$ & $=$ & $=$ & 3 & 3 & $=$ & $=$ & $=$ & $=$ & 3 & Atacadas pela agressora \\
\hline 06/03/03 & 6 & $=$ & $=$ & $=$ & $=$ & 6 & 6 & $=$ & $=$ & $=$ & $=$ & 6 & Atacadas pela agressora \\
\hline Total & 9 & $=$ & $=$ & $=$ & $=$ & 9 & 9 & $=$ & $=$ & $=$ & $=$ & 9 & $=$ \\
\hline
\end{tabular}


Tabela 12. Operárias coletadas no ninho enquanto mordiscavam outros membros da colônia C3 durante o estabelecimento. Duração: de 05 a 06/03/2003 (tempo cumulativo das observações em vídeo, 12 horas). O sinal + indica fêmea inseminada. Padrão de ovário de 1 a 5 e idade relativa de 1 a 4, cf. Mateus et al., (2004).

\begin{tabular}{|c|c|c|c|c|c|c|c|c|c|c|c|c|c|}
\hline \multirow{2}{*}{ Data } & \multirow{2}{*}{ Quantidade } & \multicolumn{5}{|c|}{ Padrão de ovário } & \multicolumn{2}{|c|}{ Inseminação } & \multicolumn{4}{|c|}{ Idade Relativa } & \multirow{2}{*}{ Observações } \\
\hline & & 1 & 2 & 3 & 4 & 5 & + & - & 1 & 2 & 3 & 4 & \\
\hline $06 / 03 / 03$ & 1 & $=$ & 1 & $=$ & $=$ & $=$ & $=$ & 1 & $=$ & $=$ & $=$ & 1 & Principal agressora \\
\hline 06/03/03 & 1 & 1 & $=$ & $=$ & $=$ & $=$ & $=$ & 1 & 1 & $=$ & $=$ & $=$ & Mordiscando outra vespa \\
\hline 06/03/03 & 5 & 5 & $=$ & $=$ & $=$ & $=$ & $=$ & 5 & & 3 & 2 & $=$ & Mordiscando outra vespa \\
\hline 09/03/03 & 3 & 3 & $=$ & $=$ & $=$ & $=$ & $=$ & 3 & $=$ & $=$ & 1 & 2 & Mordiscando outra vespa \\
\hline Total & 10 & 9 & 1 & $=$ & $=$ & $=$ & $=$ & & 1 & 3 & 3 & 3 & $=$ \\
\hline
\end{tabular}

Tabela 13. Rainhas e intermediárias coletadas em postura durante o estabelecimento da colônia C3. Duração: de 05 a 06/03/2003 (tempo cumulativo das observações em vídeo, 12 horas). O sinal + indica fêmea inseminada. Padrão de ovário de 1 a 5 e idade relativa de 1 a 4, cf. Mateus et al., (2004).

\begin{tabular}{|c|c|c|c|c|c|c|c|c|c|c|c|c|}
\hline \multirow{2}{*}{ Data } & \multirow{2}{*}{ Quantidade } & \multicolumn{5}{|c|}{ Padrão de ovário } & \multicolumn{2}{|c|}{ Inseminação } & \multicolumn{4}{|c|}{ Idade relativa } \\
\hline & & 1 & 2 & 3 & 4 & 5 & + & - & 1 & 2 & 3 & 4 \\
\hline $05 / 03 / 03$ & 23 & $\overline{=}$ & $=$ & $=$ & $=$ & 23 & $\overline{=}$ & 23 & $=$ & $=$ & 1 & 22 \\
\hline 06/03/03 & 17 & $=$ & $=$ & $=$ & $=$ & 17 & 17 & $=$ & $=$ & $=$ & $=$ & 17 \\
\hline $06 / 03 / 03$ & 48 & $=$ & $=$ & $=$ & $=$ & 48 & $=$ & 48 & $=$ & $=$ & 1 & 47 \\
\hline Total & 88 & $=$ & $=$ & $=$ & $=$ & 88 & 17 & 71 & $=$ & $=$ & 2 & 86 \\
\hline
\end{tabular}


Tabela 14. Freqüência de atos comportamentais (\%) observados durante a fase de estabelecimento da colônia C5 envolvendo as rainhas. Duração: de 17 a 20/06/2003 (tempo cumulativo das observações em vídeo = 12 horas). As siglas utilizadas para descrever os atos comportamentais das rainhas foram descritas no item Material e Métodos (página 18).

\begin{tabular}{|c|c|c|c|c|c|c|c|c|c|c|c|c|c|c|c|c|}
\hline Rainhas & IC & PO & FXO & PR & CR & RCR & CRO & CCR & RAG & TR & RR & RT & RRFX & RTFX & $\mathbf{T P}$ & $\begin{array}{c}\text { Total por } \\
\text { rainha }\end{array}$ \\
\hline R30G & 16,13 & 7,69 & 13,33 & 0,00 & 6,67 & 14,29 & 10,00 & 5,36 & 13,04 & 0,00 & 14,29 & 33,33 & 28,57 & 0,00 & 19,05 & 39 \\
\hline R3AM & 23,66 & 15,38 & 20,00 & 0,00 & 13,33 & 28,57 & 23,33 & 16,07 & 17,39 & 0,00 & 42,86 & 33,33 & 14,29 & 30,00 & 38,10 & 70 \\
\hline R3BR & 16,13 & 7,69 & 20,00 & 50,00 & 13,33 & 21,43 & 16,67 & 35,71 & 26,09 & 33,33 & 0,00 & 0,00 & 14,29 & 10,00 & 4,76 & 65 \\
\hline R3VD & 26,88 & 46,15 & 20,00 & 50,00 & 53,33 & 14,29 & 23,33 & 12,50 & 17,39 & 58,33 & 42,86 & 33,33 & 28,57 & 30,00 & 28,57 & 88 \\
\hline ROE & 17,20 & 23,08 & 26,67 & 0,00 & 13,33 & 21,43 & 26,67 & 30,36 & 26,09 & 8,33 & 0,00 & 0,00 & 14,29 & 30,00 & 9,52 & 66 \\
\hline TOTAL & 93 & 13 & 15 & 6 & 15 & 14 & 30 & 56 & 23 & 12 & 7 & 6 & 7 & 10 & 21 & 328 \\
\hline
\end{tabular}

Tabela 15. Total e duração das posturas realizadas pelas rainhas e intermediárias da colônia C5 durante o estabelecimento. Duração: de 17 a 20/06/2003 (tempo cumulativo das observações em vídeo, 12 horas).

\begin{tabular}{ccccc}
\hline Rainhas & Número de posturas & $\begin{array}{c}\text { Duração mínima em } \\
\text { segundos }\end{array}$ & $\begin{array}{c}\text { Duração máxima em } \\
\text { segundos }\end{array}$ & Média \pm DP \\
\hline R3VD & 8 & 59 & 117 & $80,87 \pm 20,78$ \\
Demais rainhas & 4 & 57 & 121 & $85,75 \pm 26,65$ \\
Intermediárias & 5 & 41 & 108 & $77,2 \pm 24,48$ \\
\hline
\end{tabular}


Tabela 16. Freqüência de atos comportamentais (\%) observados durante a fase de estabelecimento na colônia C5 envolvendo as intermediárias. Duração: de 17 a 20/06/2003 (tempo cumulativo das observações em vídeo, 12 horas). As siglas utilizadas para descrever os atos comportamentais das rainhas foram descritas no item Material e Métodos (página 20).

\begin{tabular}{|c|c|c|c|c|c|c|c|c|c|c|c|c|}
\hline $\begin{array}{c}\text { Código das } \\
\text { intermediárias }\end{array}$ & IRC & TR & IC & PO & FXO & RRI & IRT & RFX & IFX & Oof & TP & $\begin{array}{c}\text { Total por } \\
\text { intermediária }\end{array}$ \\
\hline 71 & $=$ & $=$ & 1,14 & 16,67 & 7,69 & $\overline{=}$ & $=$ & $=$ & $=$ & $=$ & 2,86 & 5 \\
\hline 177 & 50,00 & $=$ & 6,82 & 33,33 & 15,38 & $=$ & 16,67 & $=$ & $=$ & 10,00 & 14,29 & 21 \\
\hline $94 \mathrm{~L}$ & $=$ & 50,00 & 17,05 & $=$ & 7,69 & $=$ & 8,33 & $=$ & 25,00 & 10,00 & $=$ & 22 \\
\hline 95 & $=$ & $=$ & 12,50 & $=$ & 23,08 & 14,29 & 16,67 & 20,00 & 25,00 & 20,00 & 8,57 & 29 \\
\hline $91 G$ & $=$ & $=$ & 22,73 & 16,67 & 19,23 & 35,71 & $=$ & 40,00 & 50,00 & 40,00 & 22,86 & 49 \\
\hline 142 & 50,00 & $=$ & 11,36 & $=$ & 11,54 & 14,29 & 25,00 & 10,00 & $=$ & $=$ & 8,57 & 23 \\
\hline 148 & $=$ & $=$ & 5,68 & $=$ & $=$ & $=$ & 16,67 & $=$ & $=$ & 10,00 & 5,71 & 10 \\
\hline 137 & $=$ & $=$ & 5,68 & $=$ & 3,85 & $=$ & 8,33 & 10,00 & $=$ & $=$ & 14,29 & 13 \\
\hline 113 & $=$ & $=$ & 9,09 & 16,67 & $=$ & 35,71 & 8,33 & 10,00 & $=$ & 10,00 & 14,29 & 22 \\
\hline 90 & & 50,00 & 6,82 & 16,67 & 11,54 & & & 10,00 & & & 5,71 & 15 \\
\hline 171 & $=$ & $=$ & 1,14 & $=$ & $=$ & $=$ & $=$ & $=$ & $=$ & $=$ & 2,86 & 2 \\
\hline $\begin{array}{l}\text { Total por } \\
\text { categoria }\end{array}$ & 2 & 4 & 88 & 6 & 26 & 14 & 12 & 10 & 4 & 10 & 35 & 211 \\
\hline
\end{tabular}

Tabela 17. Intermediárias da colônia C5 observadas em postura e coletadas durante o estabelecimento e pós-estabelecimento. Padrão de ovário, ovócitos maturos e idade relativa, cf. Mateus et al., (2004).

\begin{tabular}{ccccccc}
\hline $\begin{array}{c}\text { Código da } \\
\text { intermediária }\end{array}$ & $\begin{array}{c}\text { Padrão de } \\
\text { ovário }\end{array}$ & $\begin{array}{c}\text { Ovócitos } \\
\text { maturos }\end{array}$ & Idade relativa & $\begin{array}{c}\text { Data de } \\
\text { marcação }\end{array}$ & Data da coleta & $\begin{array}{c}\text { Tempo de } \\
\text { observação }\end{array}$ \\
\hline 90 & P5 & 4 & 4 & $24 / 4 / 03$ & $10 / 07 / 03$ & 77 dias \\
$91 G$ & P5 & 5 & 4 & $24 / 04 / 03$ & $20 / 06 / 03$ \\
$94 \mathrm{~L}$ & P5 & 2 & 4 & $24 / 04 / 03$ & $02 / 07 / 03$ & 70 dias \\
113 & P5 & 4 & 4 & $26 / 04 / 03$ & $18 / 06 / 03$ \\
148 & P5 & 2 & 4 & $26 / 04 / 03$ & $18 / 06 / 03$ & 54 dias \\
177 & P5 & 3 & 4 & $24 / 04 / 03$ & $10 / 07 / 03$ & 78 dias \\
\hline
\end{tabular}


Tabela 18. Rainhas eliminadas durante o estabelecimento da colônia C5. (Duração: de 23 a 27/06/03). (tempo cumulativo das observações em vídeo, 10 horas). O sinal + indica fêmea inseminada. Padrão de ovário de 1 a 5 e idade relativa de 1 a 4, cf. Mateus et al., (2004).

\begin{tabular}{|c|c|c|c|c|c|c|c|c|c|c|c|c|c|}
\hline \multirow{2}{*}{$\begin{array}{l}\text { Data da coleta } \\
\text { ou eliminação }\end{array}$} & \multirow{2}{*}{ Rainhas } & \multicolumn{5}{|c|}{ Padrão de ovário } & \multicolumn{2}{|c|}{ Espermateca } & \multicolumn{4}{|c|}{ Idade relativa } & \multirow{2}{*}{ Observações } \\
\hline & & 1 & 2 & 3 & 4 & 5 & + & - & 1 & 2 & 3 & 4 & \\
\hline $24 / 06$ & R3AM & $=$ & $=$ & $=$ & $=$ & 1 & 1 & $=$ & $=$ & $=$ & $=$ & 1 & Asas cortadas, coletada no lixo \\
\hline $25 / 06$ & R30G & $=$ & $=$ & $=$ & $=$ & 1 & 1 & $=$ & $=$ & $=$ & $=$ & 1 & Refugiada em folhas \\
\hline $25 / 06$ & ROE & $=$ & $=$ & $=$ & $=$ & 1 & 1 & $=$ & $=$ & $=$ & $=$ & 1 & Refugiada em folhas \\
\hline
\end{tabular}




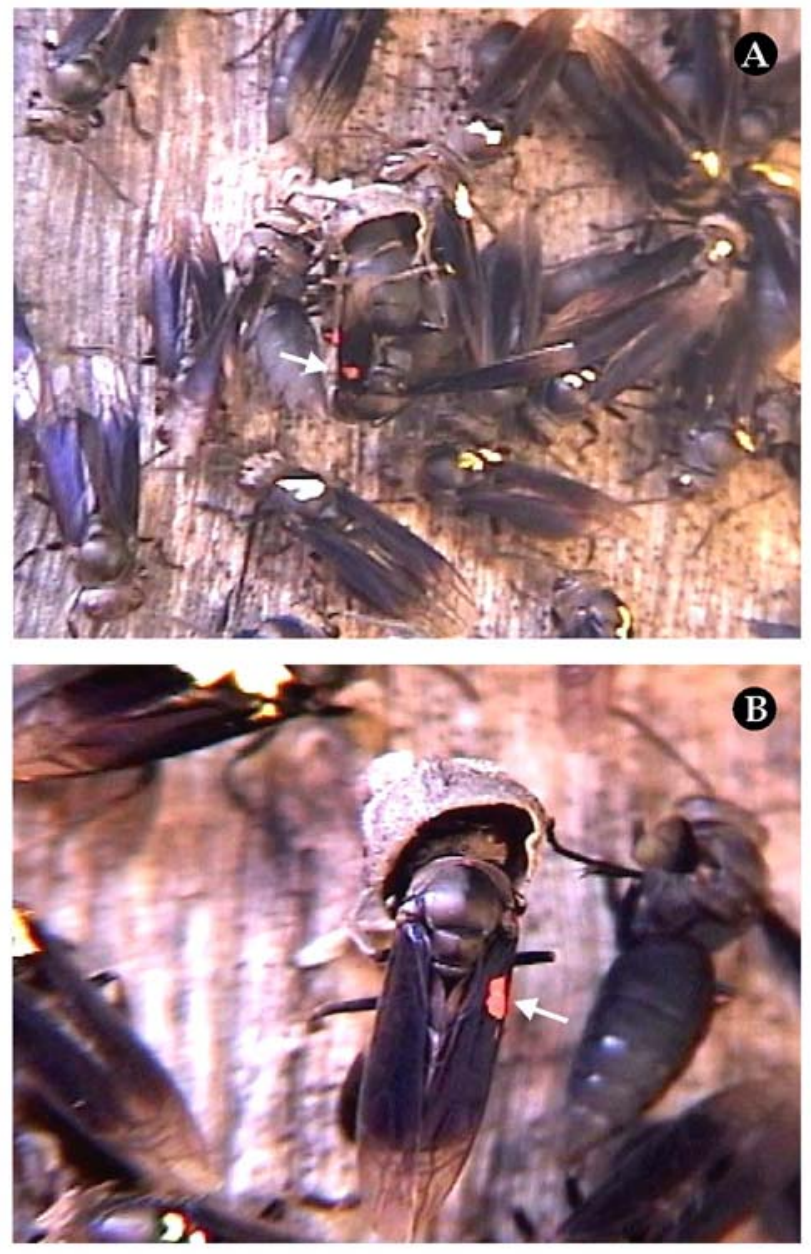

Figura 5. Fase de estabelecimento da colônia C3, intermediária (escoteira, asa vermelha): A - realizando postura; B - fixando o ovo após a postura. 

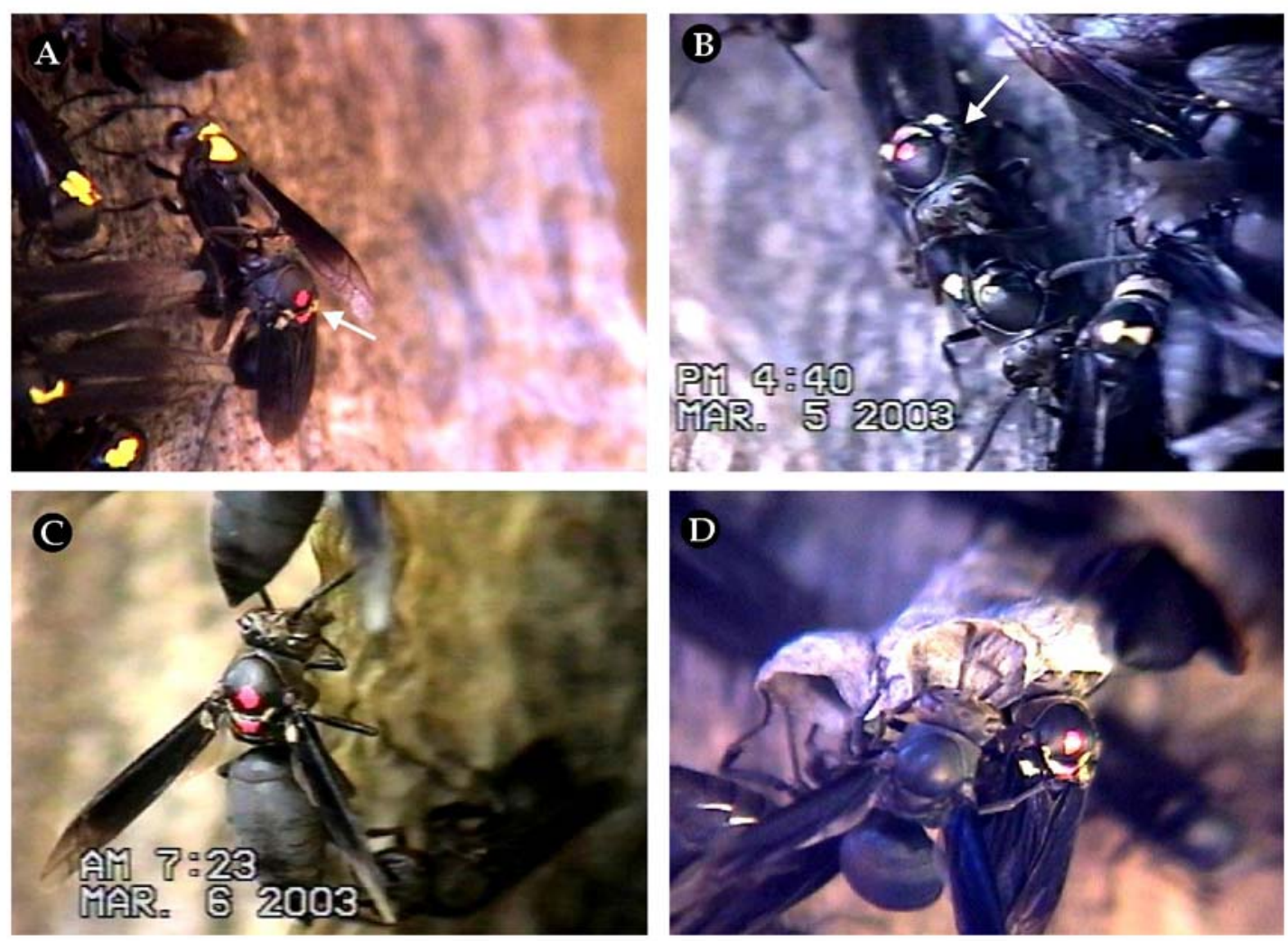

Figura 6. Fase de estabelecimento da colônia C3, agressora (escoteira) indicada pela seta: A e B prendendo rainhas pelas asas; C - construindo invólucro e D fazendo inspeção de célula. 

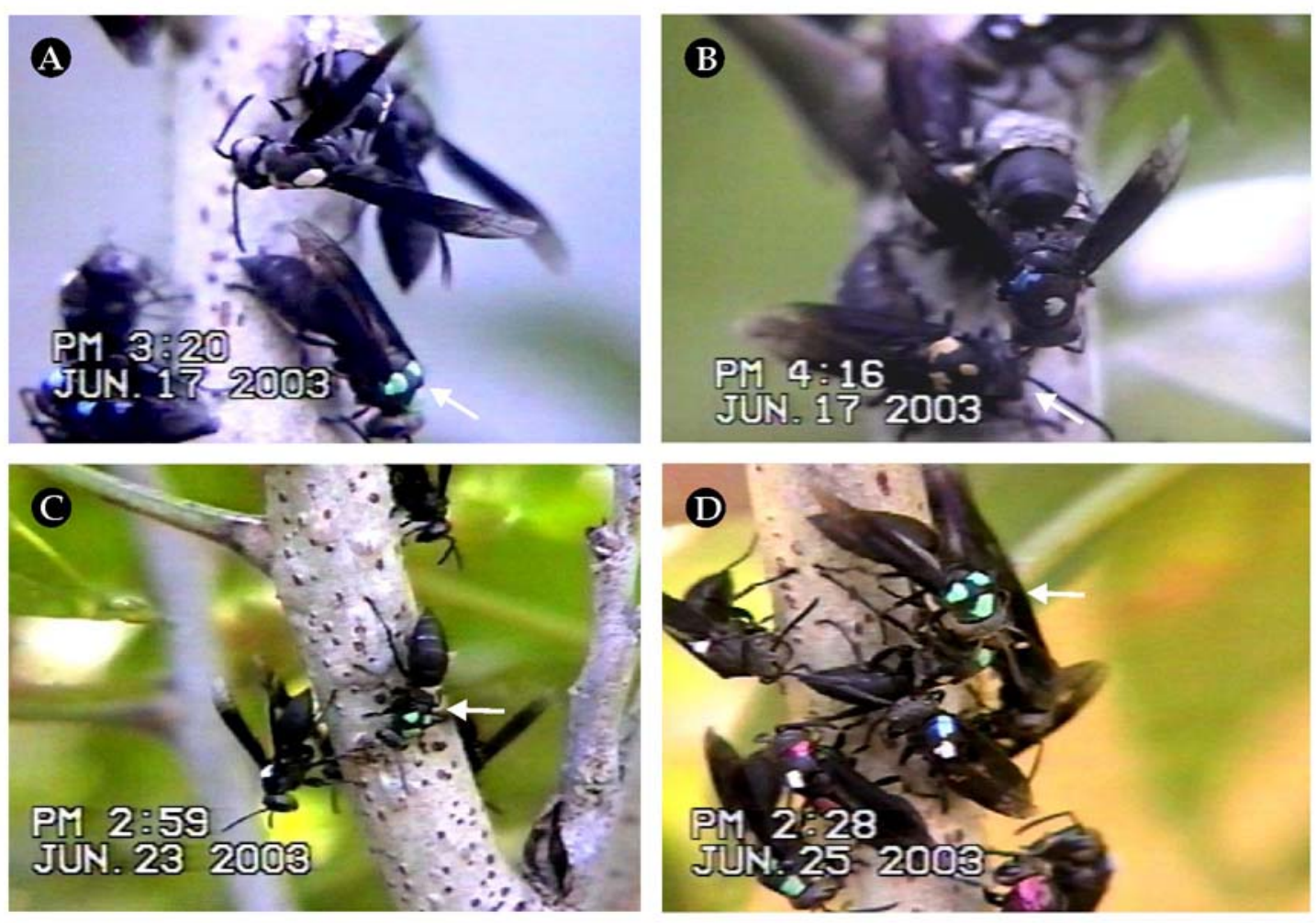

Figura 7. Fase de estabelecimento da colônia C5: A e B - postura de intermediárias na presença de rainhas, as setas indicam as rainhas código R3VD e R3AM. Comportamentos da rainha código R3VD durante a eliminação de rainhas; C - vibrando as asas durante locomoção e D - com as pernas sobre operária, mordiscando. 


\section{C.3.4 - Fase de pós-estabelecimento das colônias estudadas}

\section{C.3.4.1 - Comportamento das rainhas da colônia C1.}

Durante o pós-estabelecimento da colônia não foi observado alteração significativa no comportamento das rainhas. Novos atos comportamentais foram incluídos devido ao desenvolvimento do ninho e o surgimento de imaturos. As interações entre as rainhas da colônia diminuíram consideravelmente em relação à fase anterior. Na Tabela 19 estão relacionados os principais atos comportamentais das rainhas nesta fase da colônia. Elas ficavam mais distantes umas das outras e passavam grande parte do tempo patrulhando os favos, inspecionado as células, fixando ovos e fazendo contato bucal com larvas. Porém, os comportamentos ligados as interações competitivas por células para postura ou fixação de ovos observados durante o estabelecimento, permaneceram durante o pós-estabelecimento, sendo acrescentado oofagia nesta fase.

Nesta colônia não foram observadas interações agressivas entre as rainhas ou territórios nos favos. Observou-se oofagia feita por rainhas em células periféricas. No primeiro caso não foi possível saber qual rainha botou, no segundo o ovo foi botado por uma rainha e comido por outra. Nesta fase da colônia as células geralmente contêm ovos e imaturos e poucas células vazias são encontradas. Durante as observações as rainhas estavam botando em células centrais ou periféricas. A constatação desse tipo de oofagia sugere que outro tipo de competição pode ocorrer nesta fase do desenvolvimento da colônia, ou seja, durante o patrulhamento a rainha inspeciona dezenas de células e, provavelmente, reconhece os ovos botados por outras rainhas. Esses ovos podem ser comidos e substituídos. Dessa forma a rainha garante a produção de um número maior de indivíduos aparentados. Outro fato que pressiona a postura da rainha se refere ao fato de seus ovários sempre terem ovócitos maturos. Em ninhos onde não há células vazias elas teriam que reabsorver estes ovos, o que não faz muito sentido nesta fase do ciclo colonial. O mais plausível e vantajoso seria comer o ovo de outra rainha e botar seu ovo 
no lugar. Por outro lado, sempre têm algumas células vazias devido à emergência de novos indivíduos e a larvofagia. Mas, em colônias com muitas rainhas esta quantidade de células liberadas naturalmente pode não ser o suficiente para a taxa diária de postura das rainhas.

Os comportamentos ligados a postura continuaram com o mesmo padrão comportamental, porém o número de atos por rainhas diminuiu em relação a fase anterior. Durante o pós-estabelecimento foram medidas as durações de 23 posturas dentre 40 observadas. A média foi de 54,56 \pm 16,37 seg. Não houve diferença estatisticamente significante entre duração de postura das rainhas (ANOVA, $p=0,085$ ). Também foram medidas as durações de 12 inspeções de células, a média foi de 25,41 — 27,56 seg., e de 32 fixações de ovos, a média foi de 42,37 \pm 19,05 seg., houve uma variação na média de duração entre as rainhas (Tabela 20). O total de posturas observadas e medidas durante o estabelecimento e o pós-estabelecimento foi de 56 (Tabela 21), com média de $55,77 \pm 16,54$ seg., não houve diferença significativa na duração das posturas entre as fases (t-test, $\mathrm{p}=0,373$ ). Testando individualmente a duração das posturas das rainhas entre as fases, não foram detectadas diferenças significantes (rainha RB1 $\left(\mathrm{n}^{\mathrm{o}}=8\right)$, t-test, $\mathrm{p}=0,63$; rainha $\mathrm{R} 12\left(\mathrm{n}^{\mathrm{o}}=8\right)$, $\mathrm{t}$-test, $\mathrm{p}=$ $0,12)$.

Com o desaparecimento ou eliminação gradual das rainhas ao longo das observações não foi observado a dominância de uma rainha sobre as demais presentes no ninho. As rainhas restantes permaneceram com os mesmo comportamentos visualizados anteriormente, não foram observadas interações agressivas entre as rainhas ou entre as rainhas e operárias.

O ninho e a população foram coletados em 04/01/2002. A população era composta de 137 adultos, sendo 101 operárias sem desenvolvimento ovariano, uma operária com ovário de padrão 2, duas intermediárias com padrão 5 de desenvolvimento ovariano e 33 rainhas. Toda a população adulta tinha o apódema do quinto esternito gastral de cor preta (ver Mateus et al., 2004). 
Foram coletados 5 favos contendo 642 células com 300 pupas, 162 larvas, 148 ovos e 32 células vazias.

\section{C.3.4.2 - Longevidade das rainhas da colônia C1.}

Na colônia C1 foram marcadas 11 rainhas em 26/02/2001. Todas elas foram observadas durante o pré-enxameio, atingiram o novo local do ninho e em 28/02/2001 estavam no ninho durante o estabelecimento. Em 05/04/01 havia 9 rainhas na colônia, em 20/07/01 restava apenas a rainha B1 na colônia. Esta rainha foi observada por 166 dias após a identificação com tinta no tórax.

Após o desaparecimento das rainhas marcadas não foram observados indivíduos com síndrome comportamental de rainha na colônia, embora houvesse células com ovos nos favos. Durante o período de estudo não foram observadas agressões diretas de operárias em rainhas, ou mesmo disputas entre rainhas. Também não ocorreu a divisão ou migração de parte da população, pois não se verificou nenhum ninho nas proximidades. A maioria das rainhas desapareceu da colônia durante o período mais seco do ano.

Rainhas de Agelaia (=Stelopolybia) pallipes duraram mais de 360 dias e as de Protopolybia exigua exigua mais de 377 dias (Simões, 1977). Segundo este autor, rainhas e operárias tem uma convivência pacífica, o que pode excluir a eliminação por agressão. Em $P$. fraternus a convivência diária entre rainhas nas colônias foi considerada harmoniosa. Porém dependente da fase, durante o pósestabelecimento na colônia $\mathrm{C} 2$, as rainhas foram atacadas por operárias, o que pode ter contribuído para sua eliminação da colônia. Na colônia C5 a eliminação de rainhas ocorreu durante o pré-enxameio e estabelecimento. $\mathrm{Na}$ colônia C3 eliminação de rainhas ocorreu durante o estabelecimento. 


\section{C.3.4.3 - Comportamentos das rainhas da colônia C2 durante o Pós- estabelecimento.}

Durante o pós-estabelecimento da colônia C2 não se observou alteração significativa no comportamento das rainhas. Novos atos comportamentais foram incluídos ao próprio desenvolvimento do ninho e o surgimento de imaturos. A Tabela 22 resume os principais atos comportamentais realizados pelas rainhas durante o pós-estabelecimento.

Com o aumento no número de favos e de células as rainhas passaram a patrulhar constantemente os favos fazendo muitas inspeções em células, fixando os ovos nelas depositados e fazendo contato bucal com larvas e operárias. Os comportamentos ligados a postura mantiveram o mesmo padrão da fase anterior. Nesta fase, o comportamento de curvar o abdômen para outros membros da colônia teve baixa freqüência. Como observado durante o préenxameio e estabelecimento as rainhas não se aproximavam umas das outras.

Algumas interações competitivas tiveram baixa freqüência, porém, foi acrescentado o item oofagia durante esta fase. Não foi observada uma rainha retirar outra rainha da célula enquanto realizava postura ou fixava ovo. Isso difere do que foi observado na colônia $\mathrm{C} 1$ onde as rainhas competiam por célula para postura e também, pela fixação do ovo, mesmo quando este fora botado por outra rainha. Além disso, elas não ficavam agrupadas com os corpos encostados. Foram observadas 3 oofagias feitas por diferentes rainhas em células periféricas. Ademais, na colônia não havia intermediária botando. Portanto, a oofagia feita em ovos de outras rainhas nesta fase é claramente competitiva, embora não se tivesse observado dominância explícita entre as rainhas.

O comportamento de postura das rainhas não diferiu entre as colônias. Observaram-se os mesmos padrões de inspeções de células, posturas e fixações de ovos. Durante o período de observações registrou-se o tempo de duração de 11 posturas $(46,69 \pm 6,26$ seg.). Não foi estatisticamente significante a duração das posturas entre as rainhas (ANOVA $p=0,68$ ). A duração de 13 
comportamentos de fixação de ovos (24,15 \pm 9,91 seg.), e as medidas de duração de 8 inspeções de células antes da postura (14,12 \pm 13,45 seg.). O número de posturas observadas nesta colônia foi inferior ao da colônia $\mathrm{C}$, porém houve variação no valor da média de duração de postura das rainhas (Tabela 23).

\section{C.3.4.4 - Longevidade e eliminação agressiva de rainhas na colônia C2.}

Na colônia C2 foram marcadas 10 rainhas em 22/03/2001. No LNN foram vistas 8 delas durante o estabelecimento. Em 06/04/01 todas essas rainhas estavam presentes no ninho. Durante observações feitas em 21/07/01 foram observadas as mesmas 8 rainhas, das quais três estavam com as asas danificadas. Uma delas (código 2) com uma das asas cortada próximo da base (Fig. 8 A), estava sendo agredida pelas operárias.

As agressões foram observadas 78 dias após o início do estabelecimento. Em 09/08/01 foram vistas 7 rainhas. As operárias reagiam agressivamente e atacavam com mordidas quando as rainhas tentavam fazer contato bucal. Outras rainhas foram agredidas enquanto se locomoviam pelos favos (Tabela 23). Em $04 / 10 / 01$ havia 6 rainhas na colônia. A rainha de número 2 mesmo com as asas cortadas permanecia no ninho (Fig. 8 B), e as demais também estavam sendo tratadas com agressões pelas operárias. Sugere-se que essas rainhas teriam perdido sua dominância química e por isso estariam sendo agredidas. Porém, não foi observada nenhuma rainha nova no ninho, ou intermediária fazendo postura. Em 13/10/01 havia 5 rainhas no ninho. Estavam ativas, fazendo inspeções de células, posturas e contato bucal com larvas. Nas células periféricas havia vários ovos. As operárias continuavam agressivas com as rainhas, mas não foram observados mais contatos bucais entre rainhas e operárias. Desde que foram marcadas, as últimas rainhas permaneceram na colônia 237 dias.

Na observação do dia 22/11/01 não havia mais rainhas marcadas no ninho. A julgar pelas agressões já descritas supõe-se que elas tenham sido eliminadas pelas operárias. Indivíduos não marcados foram observados 
realizando postura no ninho. Estes indivíduos apresentavam síndrome comportamental de rainha, curvavam o abdômen para outros membros da colônia e foram observados em contato corporal ou agrupados; possivelmente eram rainhas jovens. Nesta data também foram observados vários machos no interior da colônia, provavelmente jovens.

A população do ninho enxameou no final de dezembro de acordo com informações das pessoas residentes no local.

Nas colônias C3 e C5 os ataques das agressoras foram primeiramente nas asas, deixando as rainhas impossibilitadas de voar. E em $\mathrm{Pa}$. smithii o mesmo tipo de ataque foi observado (S. Mateus, não publ.).

Em uma colônia de Polybia micans o mesmo deve ter ocorrido, pois havia uma única rainha no ninho com as asas cortadas junto ao tórax (S. Mateus, não publ.). Rainhas sem as asas ficam vulneráveis ao ataque de outros membros da colônia, pois se forem jogadas ou expulsas do ninho estarão condenadas ao ataque de diversos predadores. Na colônia C2, mesmo com as asas danificadas, algumas rainhas permaneceram no ninho. Elas, apesar de agredidas, realizavam posturas. Durante este período não se observou nenhuma outra rainha ou intermediária fazendo posturas.

Estes resultados mostraram que as rainhas velhas são eliminadas gradualmente, caracterizando a oligoginia cíclica, até que a colônia fique com uma ou poucas rainhas (West-Eberhard, 1978a). Depois disso, as novas rainhas começam a realizar posturas. Nossas observações confirmam que as operárias são as principais responsáveis pela eliminação das rainhas. Porém, na colônia C5, uma das rainhas participou ativamente da eliminação de outras rainhas.

Nas colônias C1 e C2, novas rainhas foram observadas somente depois do desaparecimento das rainhas marcadas. Entre os prováveis motivos que levaram a eliminação das rainhas, pode-se supor que: a - com um grande número de rainhas presentes no ninho e a sobreposição de várias gerações de operárias, estas perderam a identidade genética com as rainhas-mães, b - com o aumento da idade possíveis feromônios envolvidos na expressão do "status" 
real, deixaram de ser produzidos. Convém ressaltar que durante as observações todas as rainhas marcadas durante o pré-enxameio permaneceram com 0 "status" de rainha até seu desaparecimento da colônia. Ao contrário do que foi afirmado por West-Eberhard (1978a), jamais se viu uma rainha realizando tarefas de operárias. Também não se observou nenhuma operária testando rainhas como observado por West-Eberhard (1978a) e Nascimento (2003).

\section{C.3.4.5 - Pós-estabelecimento da colônia C3.}

Em 09/03/03 ainda estava ocorrendo o comportamento de mordiscar entre os membros da população como observado em 05/03/03 durante o estabelecimento. Foram observados inclusive indivíduos que foram escoteiras durante o pré-enxameio mordiscando e sendo mordiscadas (Fig. $8 \mathrm{C}$ ).

Este comportamento não foi direcionado para um determinado grupo de indivíduos da colônia, já que os indivíduos que realizavam o comportamento também recebiam o mesmo tratamento, conforme relatado por Platt et al., (2004). Foram observados poucos indivíduos tentando botar. Como relatado anteriormente, foram coletadas rainhas e intermediárias em postura. Entretanto, havia varias células com ovos nos favos. Nesta data (09/03/03), foram coletadas 2 fêmeas não jovens em postura, uma rainha com pouco desenvolvimento ovariano e uma intermediária; isto mostrou que a colônia não estava órfã.

Algumas vespas após serem mordiscadas deixavam o interior do ninho e ficavam fora do invólucro, ou pousavam próximas do ninho em folhas, ramos etc. Foram coletadas 3 operárias que mordiscavam outras vespas, e 8 indivíduos refugiados fora do ninho. Entre os que deixaram o ninho não havia intermediárias, eram indivíduos jovens e com pouco desenvolvimento ovariano. Não se pode saber qual a razão dos atos agressivos em operárias com pouco desenvolvimento ovariano. Sugere-se ser o reconhecimento das futuras poedeiras (rainhas/intermediárias). As vespas que mordicavam também não apresentavam desenvolvimento ovariano e não eram jovens (Tabela 24). Platt et al., (2004) também não encontraram correlação entre indivíduos agredidos e agressores em colônias de Pa. colobopterus. Em 20/03/03 o invólucro do ninho 
estava totalmente fechado. Não foi construído tubo de entrada típico da espécie, mas apenas um orifício de diâmetro reduzido (Fig. 8 D). Novas células foram adicionadas aos favos, a maioria das quais estavam com ovos, significando que restavam fêmeas com ovários desenvolvidos no ninho.

Foram marcados com cores diferentes os indivíduos que estavam tentando realizar posturas, os que mordiscavam e os que recebiam este comportamento. O comportamento de mordiscar e ser mordiscado eram recíprocos, e não unidirecional. Os indivíduos marcados enquanto tentavam realizar posturas foram confirmados posteriormente realizando posturas e não foram mordiscados ou impedidos de botar. Uma escoteira foi coleta no chão com asa direita cortada na base. Esta fêmea foi observada anteriormente mordiscando outros indivíduos da colônia. Ela não estava com os ovários desenvolvidos e não era jovem. Como não havia fêmeas com síndrome comportamental de rainha na colônia e pelo fato da entrada do ninho estar fora do padrão de arquitetura da espécie, tudo apontava para a orfandade da colônia. Em 03/04/03 a entrada do ninho continuava atípica, foram observadas 15 posturas. Como as poedeiras não apresentavam síndrome comportamental de rainha, isso tudo sugeria a orfandade da colônia. O comportamento de mordiscar foi também observado na colônia C5, onde ocorreu após a eliminação das rainhas e início da fase monoginica. Ele seguiu o mesmo padrão observado nesta colônia.

A população da colônia e o ninho foram coletados 30 dias após a migração para o local do novo ninho. No total havia 227 indivíduos, sendo 85 intermediárias (padrão ovariano 5), e nenhuma fêmea inseminada (Tabela 25).

A ausência de rainhas na população fez aumentar consideravelmente o número de intermediárias, fêmeas que tentavam se tornar rainhas, e que não eram indivíduos jovens. A falta de machos em ninhos nas proximidades provavelmente contribuiu para a não inseminação das futuras rainhas.

Considerando que quando o ninho foi destruído estava produzindo machos e possivelmente novas rainhas, é possível que entre as intermediárias pudesse estar alguma rainha jovem e não inseminada. Outra possibilidade seria 
a de que qualquer fêmea da colônia capacitada a desenvolver seus ovários pudesse, na presença ou ausência de rainhas, ser inseminada e tornar-se rainha. Após remover todas as rainhas e indivíduos tentando realizar posturas numa colônia de $\mathrm{Pa}$. colobopterus, confirmou-se o aparecimento de uma nova rainha após 7 dias (Strassmann et al., 2002). Esta nova rainha poderia ter estado entre os adultos ou pupas na colônia.

\section{C3.4.6 - Pós-estabelecimento da colônia C5.}

\section{C.3.4.6.1 - Comportamento da rainha e das intermediárias durante a monoginia.}

Após a eliminação das rainhas durante a fase de estabelecimento, com o retorno a monoginia, a rainha voltou a se comportar como observado anteriormente, tanto na fase de produção de operárias, como no início do estabelecimento, isto é, voltou a realizar posturas, a ficar nas proximidades do favo ou parada sob o invólucro (Fig. 9 A), curvar o abdômen para as operárias, fazer inspeções nas células, fixar ovos e fazer contato bucal com operárias.

Depois da fase crítica de eliminação de rainhas, as atividades de forrageio e construções voltaram à normalidade. Houve crescimento do número de células, e também na altura do invólucro. Na Tabela 26 estão relacionados os principais atos comportamentais realizados pela rainha e intermediárias durante a fase monogínica. Os comportamentos ligados a postura observados entre as intermediárias e a rainha mantiveram o mesmo padrão observado no início do estabelecimento, assim como as interações competitivas. As intermediárias voltaram a ficar nas proximidades do favo competindo umas com as outras e com a rainha por células vazias para realização de postura (Fig. 9 B). Nesta fase não se observou oofagia, mas não descartamos a possibilidade de ela ter ocorrido.

Embora com baixa freqüência, o comportamento de mordiscar continuou durante esta fase. Algumas intermediárias foram mordiscadas, porém continuaram na região do favo realizando posturas e fixando ovos. No entanto, não ficou claro a natureza deste comportamento que se iniciou na fase de 
eliminação de rainhas (colônia C3 e C5). Como ele difere do comportamento de limpeza corporal típico, pode-se concordar com outros autores (Jeanne, 1991; 1995; O`Donnell, 2001) que afirmam serem esses comportamentos estimulações para a realização de tarefas na colônia.

Foram medidas as durações de três posturas da rainha (76 \pm 23,81 seg.), e de quatro posturas de intermediárias (83,66 \pm 35,23 seg.), (Tabela 27). Não houve diferença estatisticamente significante entre a duração das posturas da rainha e das intermediárias (Mann-Whitney Rank Sum Test, $p=0,857$ ). O padrão do comportamento de posturas da rainha e das intermediárias mantevese como observado anteriormente.

Algumas intermediárias permaneceram na colônia até 102 dias após serem codificadas (Tabela 28). Durante a fase de produção de operárias estiveram ligadas a tarefas de construção, manutenção da colônia e forrageio. Desde o início do estabelecimento foram observadas sempre na região do favo realizando posturas, fixando ovos e fazendo inspeção de células, exceto durante o período de eliminação de rainhas, porém não foram agredidas por outros membros da colônia.

Durante as observações realizadas em 05/08/04, à rainha R3VD ainda estava na colônia, e não foi observada qualquer alteração em seu comportamento. Também se observou a presença de duas intermediárias. Tanto a rainha como as intermediárias comportavam-se como observado anteriormente e não se observou nenhum ato sugestivo de agressão. Em 20/11/03 a rainha e as intermediárias não foram observadas na colônia. Não foram observadas fêmeas com síndrome comportamental de rainha, não foram observadas posturas ou atos agressivos entre os membros da colônia. O ninho e a população foram coletados em 05/12/03. Nele havia apenas uma fêmea inseminada e com os ovários desenvolvidos, 14 operárias e 15 machos de idades diferentes. Nos 3 favos havia 21 células vazias, 97 células com ovos, 34 células com larvas e 37 pupas, destas 28 pupas de machos.

A rainha substituta (fêmea de código 261) coletada juntamente com o ninho em 05/12/03 foi observada durante 192 dias após ter recebido o código 
de cores. Durante a fase de produção de operárias, ela foi observada fazendo contato bucal com larvas e adultos e, também, construindo envelope, macerando e dividindo polpa com outras construtoras (Fig. 9 C). Durante o estabelecimento ela foi observada fazendo contato bucal com outras operárias e, durante a eliminação de rainhas, foi observada mordiscando outras operárias no invólucro. Durante a fase monogínica ela foi vista fazendo contatos bucais com larvas e adultos, mordiscando operárias no ninho, limpando operária e sendo limpa por outras operárias.

Ela nunca foi observada realizando atividades externas, como coleta de alimento ou material de construção. Esta fêmea não apresentou síndrome comportamental de rainha ou se comportou como intermediária durante $\mathrm{o}$ período em que a colônia foi observada. A colônia não estava sendo observada quando a R3VD foi substituída pela operária de código 261. Esta fêmea não era jovem, estava inseminada e com os ovários bem desenvolvidos (Fig. 9 D), padrão 5 conforme Mateus et al., (2004).

A alta produção de machos provavelmente deve estar relacionada com o período em que a rainha substituta ainda não estava inseminada. Certamente ela foi inseminada por macho produzido na mesma colônia, pois não ocorre esta espécie de vespa na área de estudos.

Nesta colônia foi observado um caso autêntico de substituição de rainha por uma operária. A não ser que nesta espécie, as rainhas consigam ficar na colônia desenvolvendo outras atividades esperando uma oportunidade, como a monoginia ou redução no número de rainhas, para copular e se tornar rainha. Outra possibilidade seria a orfandade da colônia, desse modo, uma operária desenvolveria os ovários, e com a cópula assumiria o papel de rainha.

Assumindo que a determinação de castas em $P$. fraternus é pós-imaginal, todas as operárias têm a possibilidade de se tornar rainha dentro de uma determinada faixa etária, pois todas desenvolvem ovários durante um período da vida.

A fêmea que se tornou rainha foi observada por 192 dias após ter recebido o código de cores, esta é uma idade relativamente alta para operária, embora ainda não temos esta informação. Embora Simões (1977) tenha 
constatado que a idade média de operárias de Pr. exigua exigua foi de 25,60 \pm 16,80 dias, e de $A$. (=Stelopolybia) pallipes de 21,94 \pm 8,5 dias, convém ressaltar que em Pr. exigua exigua e em A. (=Stelopolybia) pallipes a diferenciação de castas é pré-imaginal, rainhas morfologicamente distintas e maiores que operárias, diferente do observado em $P$. fraternus que apresenta baixa diferenciação entre as castas (Mateus et al., 2004).

\section{C.3.4.6.2 - Alimentação das rainhas durante o pré-enxameio e estabelecimento.}

A duração do pré-enxameio nos ninhos estudados de $P$. fraternus foi variável (Tabela 2), as rainhas passam por um período longo com pouco alimento, elas obtiveram alimento através de poucos contatos bucais entre elas que foram raros e com as operárias que foram mais freqüentes. Também foram vistas dividindo presa com as operárias. Diferentes das rainhas de Polistes e Mischocyttarus, elas não deixam o ninho para forragear alimento, logo são totalmente dependentes de outros membros da colônia, adultos ou imaturos para alimentar-se.

Durante o pré enxameio da colônia C1, as rainhas conseguiram alimento através dos contatos bucais feitos com as operárias. Não foi observada a entrada de alimento sólido durante esta fase e as rainhas raramente deixaram o substrato do ninho original. Na colônia C2 as rainhas fizeram mais contatos bucais com operárias, várias forrageadoras foram observadas pousando com proteína animal no ninho, as rainhas eram atraídas provavelmente pelo odor do alimento e participavam da divisão ou pegavam de alguma operária.

Durante o estabelecimento as rainhas iniciaram a postura de ovos podendo ou não ocorrer oofagia. Na fase de estabelecimento não foi observada a oofagia feita por rainhas em ovos de rainhas ou de intermediárias. Os ovos botados se tornaram larvas dentro de aproximadamente 10 dias, e é possível que a partir do surgimento de larvas no ninho as rainhas passem a se alimentar com mais regularidade fazendo contato bucal com os imaturos. 
As rainhas da tribo Epiponini geralmente têm grande quantidade de tecido adiposo no gaster, o que provavelmente garantirá a sobrevivência dos indivíduos durante períodos de escassez de alimento ou durante migrações independente da causa.

Em Meliponinae as colônias são fundadas antes da chegada da rainha, as operárias levam alimento da colônia original que é depositado em potes, desta forma a população da colônia nova e a rainha não passam por períodos críticos de falta de alimento. 
Tabela 19. Freqüência de atos comportamentais (\%) observados durante a fase de pós-estabelecimento na colônia $\mathrm{C} 1$ envolvendo as rainhas. Duração: início 03/03/2001 a 23/11/2001 (tempo cumulativo das observações em vídeo, 25 horas). As siglas utilizadas para descrever os atos comportamentais das rainhas foram descritas no item Material e Métodos (página 18).

\begin{tabular}{|c|c|c|c|c|c|c|c|c|c|c|c|c|c|c|c|c|}
\hline Rainhas & IC & PO & FXO & PR & CR & RCR & CRO & CCR & LC & TR & TR-R & RRFX & RTFX & Oof & CBL & $\begin{array}{c}\text { Total por } \\
\text { rainha }\end{array}$ \\
\hline R1 & 9,43 & 7,50 & 8,70 & 5,88 & - & 7,69 & 3,85 & 25,00 & - & 15,38 & 25,00 & 14,29 & 18,75 & 50,00 & 10,00 & 46 \\
\hline $\mathrm{R} 2$ & 6,29 & 10,00 & 10,14 & - & - & - & 7,69 & - & - & - & 25,00 & - & 6,25 & - & - & 25 \\
\hline R3 & 5,03 & 7,50 & 5,80 & - & - & - & 3,85 & - & - & - & 25,00 & 14,29 & - & - & 2,00 & 20 \\
\hline R6 & 5,66 & 2,50 & 4,35 & 11,76 & 15,38 & - & 19,23 & 12,50 & 13,04 & - & - & 7,14 & 12,50 & - & 14,00 & 37 \\
\hline R7 & 8,18 & 5,00 & 4,35 & 17,65 & - & 7,69 & 3,85 & 25,00 & 8,70 & - & - & 7,14 & 6,25 & - & 8,00 & 33 \\
\hline R8 & 12,58 & 12,50 & 11,59 & 11,76 & - & 15,38 & 3,85 & - & 8,70 & 30,77 & 25,00 & - & 6,25 & - & 10,00 & 52 \\
\hline R10 & 16,35 & 22,50 & 20,29 & - & - & 7,69 & 7,69 & - & 4,35 & - & - & 35,71 & 25,00 & - & 4,00 & 65 \\
\hline R11 & 3,77 & 5,00 & 2,90 & - & - & 15,38 & - & - & 26,09 & 7,69 & - & - & - & - & - & 19 \\
\hline R12 & 11,32 & 7,50 & 11,59 & - & 23,08 & 7,69 & - & - & 13,04 & 7,69 & - & 7,14 & 6,25 & - & 16,00 & 50 \\
\hline RB1 & 9,43 & 15,00 & 13,04 & 52,94 & 38,46 & 23,08 & 19,23 & - & 13,04 & 15,38 & - & 7,14 & - & - & 20,00 & 70 \\
\hline RB2 & 11,95 & 5,00 & 7,25 & - & 23,08 & 15,38 & 30,77 & 37,50 & 13,04 & 23,08 & - & 7,14 & 18,75 & 50,00 & 16,00 & 64 \\
\hline $\begin{array}{l}\text { Total por } \\
\text { categoria }\end{array}$ & 159 & 40 & 69 & 17 & 13 & 13 & 26 & 8 & 23 & 13 & 4 & 14 & 16 & 2 & 50 & 477 \\
\hline
\end{tabular}


Tabela 20. Total de posturas realizadas por cada rainha da colônia C1 durante o pósestabelecimento. Duração: início 03/03/2001 a 23/11/2001 (tempo cumulativo das observações em vídeo, 25 horas).

\begin{tabular}{ccccc}
\hline Rainhas & $\begin{array}{c}\text { Número de posturas } \\
\text { por rainha }\end{array}$ & $\begin{array}{c}\text { Duração mínima em } \\
\text { segundos }\end{array}$ & $\begin{array}{c}\text { Duração máxima em } \\
\text { segundos }\end{array}$ & Média \pm DP \\
\hline R1 & 1 & - & - & 53 \\
R2 & 1 & - & - & 99 \\
R3 & 3 & 38 & 79 & $61,33 \pm 21,07$ \\
R8 & 3 & 71 & 47 & $57 \pm 12,48$ \\
R10 & 5 & 33 & 58 & $44,8 \pm 10,37$ \\
R12 & 4 & 31 & 49 & $40 \pm 8,40$ \\
RB1 & 5 & 73 & 52 & $59,8 \pm 9,33$ \\
RB2 & 1 & - & - & 65 \\
- & 23 & 49,2 & 57 & - \\
\hline
\end{tabular}

Tabela 21. Total de posturas observadas por cada rainha da colônia C1 durante todo o período de observação (fase de estabelecimento e pós-estabelecimento).

\begin{tabular}{ccccc}
\hline Rainhas & $\begin{array}{c}\text { Número de posturas } \\
\text { por rainha }\end{array}$ & $\begin{array}{c}\text { Duração mínima em } \\
\text { segundos }\end{array}$ & $\begin{array}{c}\text { Duração máxima em } \\
\text { segundos }\end{array}$ & Média \pm DP \\
\hline R1 & 3 & 41 & 53 & $47,66 \pm 6,11$ \\
R2 & 3 & 45 & 99 & $69,33 \pm 27,39$ \\
R3 & 6 & 37 & 100 & $63,33 \pm 24,32$ \\
R6 & 4 & 42 & 52 & $46 \pm 4,546$ \\
R7 & 2 & 45 & 52 & $48,5 \pm 4,94$ \\
R8 & 6 & 40 & 71 & $54,5 \pm 10,93$ \\
R10 & 6 & 33 & 72 & $49,33 \pm 14,47$ \\
R11 & 8 & 37 & 101 & $61,62 \pm 20,01$ \\
R12 & 8 & 31 & 91 & $50,12 \pm 18,15$ \\
RB1 & 8 & 52 & 73 & $58,37 \pm 9,78$ \\
RB2 & 2 & 53 & 65 & $59 \pm 8,48$ \\
- & 56 & 41,45 & 75,36 & - \\
\hline
\end{tabular}


Tabela 22. Freqüência de atos comportamentais (\%) observados durante a fase de pós-estabelecimento na colônia C2 envolvendo as rainhas. Duração: início 06/04/2001 a 04/11/2001 (tempo cumulativo das observações em vídeo, 15 horas). As siglas utilizadas para descrever os atos comportamentais das rainhas foram descritas no item Material e Métodos (página 18).

\begin{tabular}{|c|c|c|c|c|c|c|c|c|c|c|c|c|c|c|}
\hline Rainhas & IC & PO & FXO & PR & $\mathbf{A L}$ & CR & RCR & CRO & LC & TR & AGR & Oof & CBL & $\begin{array}{c}\begin{array}{c}\text { Total por } \\
\text { rainha }\end{array} \\
\end{array}$ \\
\hline $\mathrm{R} 2$ & 16,88 & 18,18 & 13,64 & 7,55 & - & - & 25,00 & - & 25,71 & 25,00 & 8,33 & 33,33 & 16,30 & 65 \\
\hline $\mathrm{R} 4$ & 19,48 & 9,09 & 9,09 & 5,66 & 20,00 & 12,50 & 37,50 & 20,00 & 5,71 & 25,00 & 33,33 & - & 15,22 & 65 \\
\hline R5 & 6,49 & 9,09 & 4,55 & 7,55 & - & 12,50 & 12,50 & - & 8,57 & 12,50 & - & 33,33 & 6,52 & 29 \\
\hline R6 & 9,09 & 18,18 & 18,18 & 11,32 & - & 12,50 & - & - & 11,43 & - & - & 33,33 & 8,70 & 40 \\
\hline R7 & 12,34 & 18,18 & 18,18 & 15,09 & 40,00 & - & - & 20,00 & 8,57 & 12,50 & 16,67 & - & 10,87 & 53 \\
\hline R8 & 11,69 & 9,09 & 9,09 & 15,09 & - & 62,50 & - & 20,00 & 14,29 & 12,50 & 16,67 & - & 15,22 & 57 \\
\hline R9 & 11,69 & 9,09 & 18,18 & 9,43 & 20,00 & - & 12,50 & - & 11,43 & - & 16,67 & - & 14,13 & 49 \\
\hline R11 & 12,34 & 9,09 & 9,09 & 28,30 & 20,00 & - & 12,50 & 40,00 & 14,29 & 12,50 & 8,33 & - & 13,04 & 61 \\
\hline $\begin{array}{l}\text { Total por } \\
\text { categoria }\end{array}$ & 154 & 11 & 22 & 53 & 5 & 8 & 8 & 5 & 35 & 8 & 12 & 3 & 92 & 419 \\
\hline
\end{tabular}


Tabela 23. Número total de posturas realizadas pelas rainhas da colônia C2 durante todo o período de observação (fase de estabelecimento e pós-estabelecimento).

\begin{tabular}{ccccc}
\hline Rainhas & $\begin{array}{c}\text { Número de } \\
\text { posturas por rainha }\end{array}$ & $\begin{array}{c}\text { Duração mínima em } \\
\text { segundos }\end{array}$ & $\begin{array}{c}\text { Duração máxima em } \\
\text { segundos }\end{array}$ & Média \pm DP \\
\hline R2 & 2 & 41 & 47 & $44 \pm 4,24$ \\
R4 & 1 & - & 41 & - \\
R5 & 1 & - & 48 & - \\
R6 & 2 & 46 & 47 & $46,5 \pm 0,70$ \\
R7 & 2 & 38 & 55 & $46,5 \pm 12,02$ \\
R8 & 1 & - & 58 & - \\
R9 & 3 & 42 & 56 & $46,67 \pm 8,08$ \\
R11 & 1 & - & 46 & - \\
- & 13 & 41,75 & 49,75 & - \\
\hline
\end{tabular}

Tabela 24. Pós-estabelecimento da colônia C3. Operárias coletadas fora do ninho, refugiadas em diversos substratos após serem agredidas, operárias agressoras coletadas no ninho. Duração: de 09/03 a 03/04/03 (tempo cumulativo das observações em vídeo, 12 horas). O sinal + indica fêmea inseminada. Padrão de ovário de 1 a 5 e idade relativa de 1 a 4, cf. Mateus et al., (2004).

\begin{tabular}{|c|c|c|c|c|c|c|c|c|c|c|c|c|c|}
\hline \multirow{2}{*}{ Data } & \multirow{2}{*}{ Quantidade } & \multicolumn{5}{|c|}{ Padrão de ovário } & \multicolumn{2}{|c|}{ Inseminação } & \multicolumn{4}{|c|}{ Idade relativa } & \multirow{2}{*}{ Observações } \\
\hline & & 1 & 2 & 3 & 4 & 5 & + & - & 1 & 2 & 3 & 4 & \\
\hline $09 / 03 / 03$ & 8 & 7 & 1 & $=$ & $=$ & $=$ & $=$ & 8 & 1 & 3 & 2 & 2 & Refugiadas, fora do ninho \\
\hline 09/03/03 & 3 & 3 & $=$ & $=$ & $=$ & $=$ & $=$ & 3 & $=$ & $=$ & 1 & 2 & Operárias agressoras \\
\hline Total & 11 & 10 & 1 & $=$ & $=$ & $=$ & $=$ & 11 & 1 & 3 & 3 & 4 & $=$ \\
\hline
\end{tabular}


Tabela 25. Composição da população da colônia C3 coletada em 03/04/2003. O sinal + indica fêmea inseminada. Padrão de ovário de 1 a 5 e idade relativa de 1 a 4, cf. Mateus et al., (2004).

\begin{tabular}{|c|c|c|c|c|c|c|c|c|c|c|c|c|c|}
\hline \multirow{2}{*}{$\begin{array}{c}\text { Data da } \\
\text { coleta }\end{array}$} & \multirow{2}{*}{ Quantidade } & \multicolumn{5}{|c|}{ Padrão de ovário } & \multicolumn{2}{|c|}{ Inseminação } & \multicolumn{4}{|c|}{ Idade relativa } & \multirow{2}{*}{ Observações } \\
\hline & & 1 & 2 & 3 & 4 & 5 & + & - & 1 & 2 & 3 & 4 & \\
\hline 03/04/03 & 222 & 102 & 5 & 7 & 9 & 85 & $=$ & 222 & $=$ & $=$ & $=$ & 222 & $\begin{array}{c}\text { Operárias e } \\
\text { intermediárias }\end{array}$ \\
\hline $03 / 04 / 03$ & 5 & 5 & $=$ & $=$ & $=$ & $=$ & $=$ & 5 & $=$ & $=$ & $=$ & 5 & Escoteiras \\
\hline Total & 227 & 107 & 5 & 7 & 9 & 85 & $=$ & 227 & $=$ & $=$ & $=$ & 227 & $=$ \\
\hline
\end{tabular}

Tabela 26. Freqüência de atos comportamentais (\%) observados durante a fase monogínica na colônia C5 envolvendo a rainha e as intermediárias. Duração: de 30/06/2003 a 05/08/2003. (tempo cumulativo das observações em vídeo, 9 horas). As siglas utilizadas para descrever os atos comportamentais das rainhas foram descritas no item Material e Métodos (página 18).

\begin{tabular}{|c|c|c|c|c|c|c|c|c|c|c|c|}
\hline $\begin{array}{l}\text { Código do } \\
\text { indivíduo }\end{array}$ & IC & PO & FXO & PR & CRO & SL & TR & TP & RRI & IRT & $\begin{array}{l}\text { Total por } \\
\text { indivíduo }\end{array}$ \\
\hline R3VD & 52,78 & 40,00 & 45,45 & 100,00 & 100,00 & - & 70,00 & 26,67 & 100,00 & - & 60 \\
\hline 137 & 8,33 & 30,00 & 27,27 & - & - & - & 5,00 & 20,00 & - & 16,67 & 15 \\
\hline 142 & 16,67 & 10,00 & 18,18 & - & - & 50,00 & 5,00 & 13,33 & - & 33,33 & 17 \\
\hline 177 & - & 10,00 & - & - & - & - & - & - & - & - & 1 \\
\hline 71 & 2,78 & - & - & - & - & - & - & 20,00 & - & 8,33 & 5 \\
\hline 90 & 2,78 & 10,00 & 9,09 & - & - & - & - & 6,67 & - & - & 4 \\
\hline $94 \mathrm{~L}$ & 16,67 & - & - & - & - & 50,00 & 20,00 & 13,33 & - & 41,67 & 18 \\
\hline $\begin{array}{l}\text { Total por } \\
\text { categoria }\end{array}$ & 36 & 10 & 11 & 9 & 3 & 2 & 20 & 15 & 2 & 12 & 120 \\
\hline
\end{tabular}


Tabela 27. Total de posturas realizadas pela rainha e intermediárias durante a monoginia da colônia C5 (pós-estabelecimento). Duração: de 30/06/2003 a 05/08/2003. (tempo cumulativo das observações em vídeo, 9 horas).

\begin{tabular}{ccccc}
\hline $\begin{array}{c}\text { Rainha e } \\
\text { intermediárias }\end{array}$ & $\begin{array}{c}\text { Número de casos } \\
\text { observados }\end{array}$ & $\begin{array}{c}\text { Duração mínima } \\
\text { em segundos }\end{array}$ & $\begin{array}{c}\text { Duração máxima } \\
\text { em segundos }\end{array}$ & Média \pm DP \\
\hline R3VD & 3 & 43 & 103 & $76 \pm 23,81$ \\
Intermediárias & 4 & 55 & 90 & $83,66 \pm 35,23$ \\
\hline
\end{tabular}

Tabela 28. Intermediárias observadas durante a fase de produção de operárias, estabelecimento e pós-estabelecimento da colônia C5, estas fêmeas não foram coletadas.

\begin{tabular}{cccccc}
\hline $\begin{array}{c}\text { Código das } \\
\text { intermediárias }\end{array}$ & $\begin{array}{c}\text { Data de } \\
\text { marcação }\end{array}$ & $\begin{array}{c}\text { Data de } \\
\text { realização de } \\
\text { postura }\end{array}$ & $\begin{array}{c}\text { Data de } \\
\text { realização de } \\
\text { oofagia }\end{array}$ & $\begin{array}{c}\text { Última } \\
\text { observação }\end{array}$ & $\begin{array}{c}\text { Tempo total de } \\
\text { observação da } \\
\text { intermediária }\end{array}$ \\
\hline 71 & $24 / 04 / 03$ & $19 / 06 / 03$ & & $09 / 07 / 03$ & 77 dias \\
95 & $26 / 04 / 03$ & $19 / 06 / 03$ & $18-19 / 06 / 03$ & $19 / 06 / 03$ & 55 dias \\
137 & $26 / 04 / 03$ & $30 / 06 / 03$ & - & $05 / 08 / 03$ & 102 dias \\
142 & $26 / 04 / 03$ & $30 / 06 / 03$ & - & $05 / 08 / 03$ & 102 dias \\
\hline
\end{tabular}



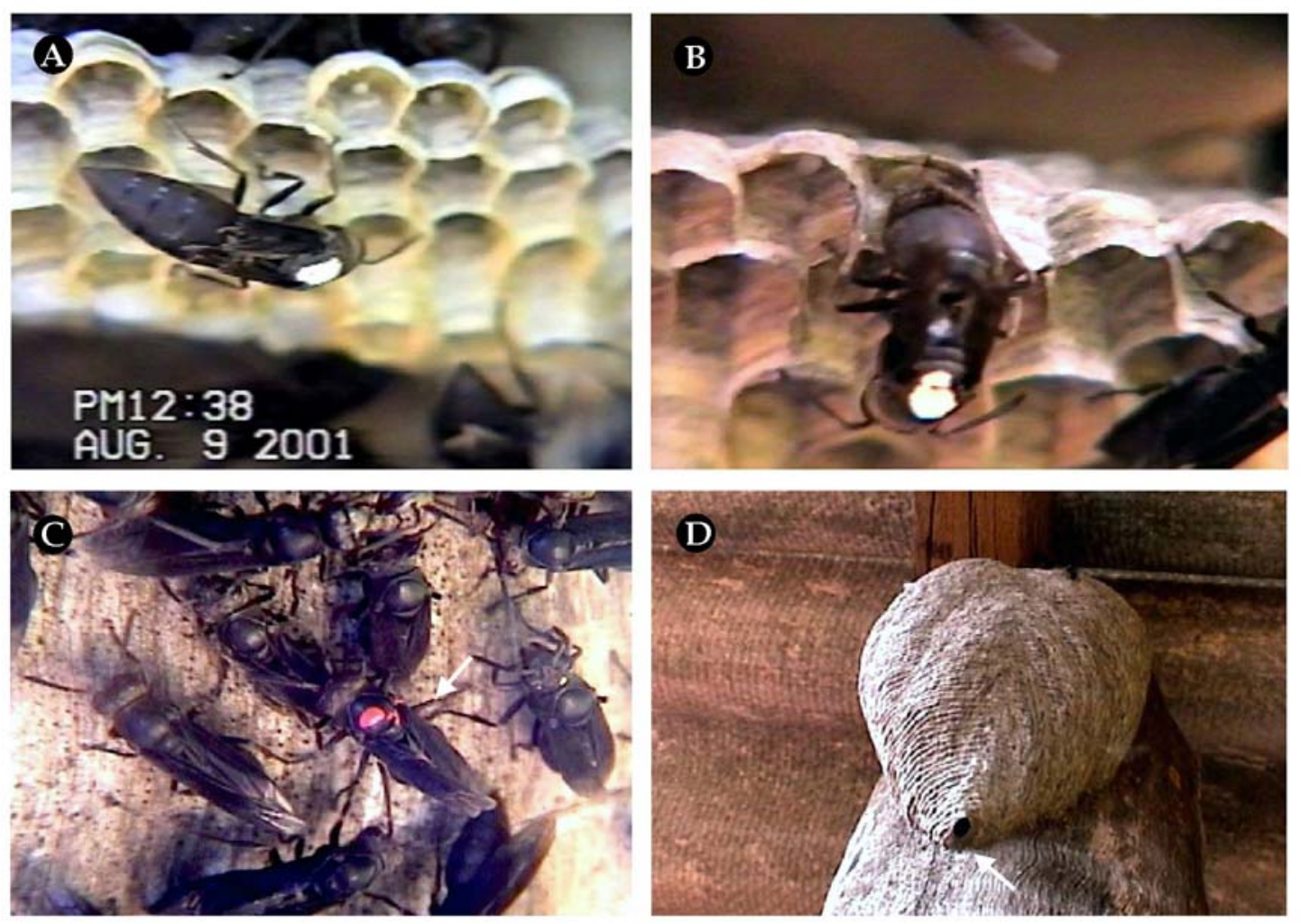

Figura 8. Fase de pós-estabelecimento da colônia C2: A - rainha (código 2) com as asas danificadas no favo; B - fazendo postura. Fase de pós-estabelecimento da colônia C3; C - escoteira mordiscando outro indivíduo da colônia; D entrada atípica do ninho em 20/03/03. 

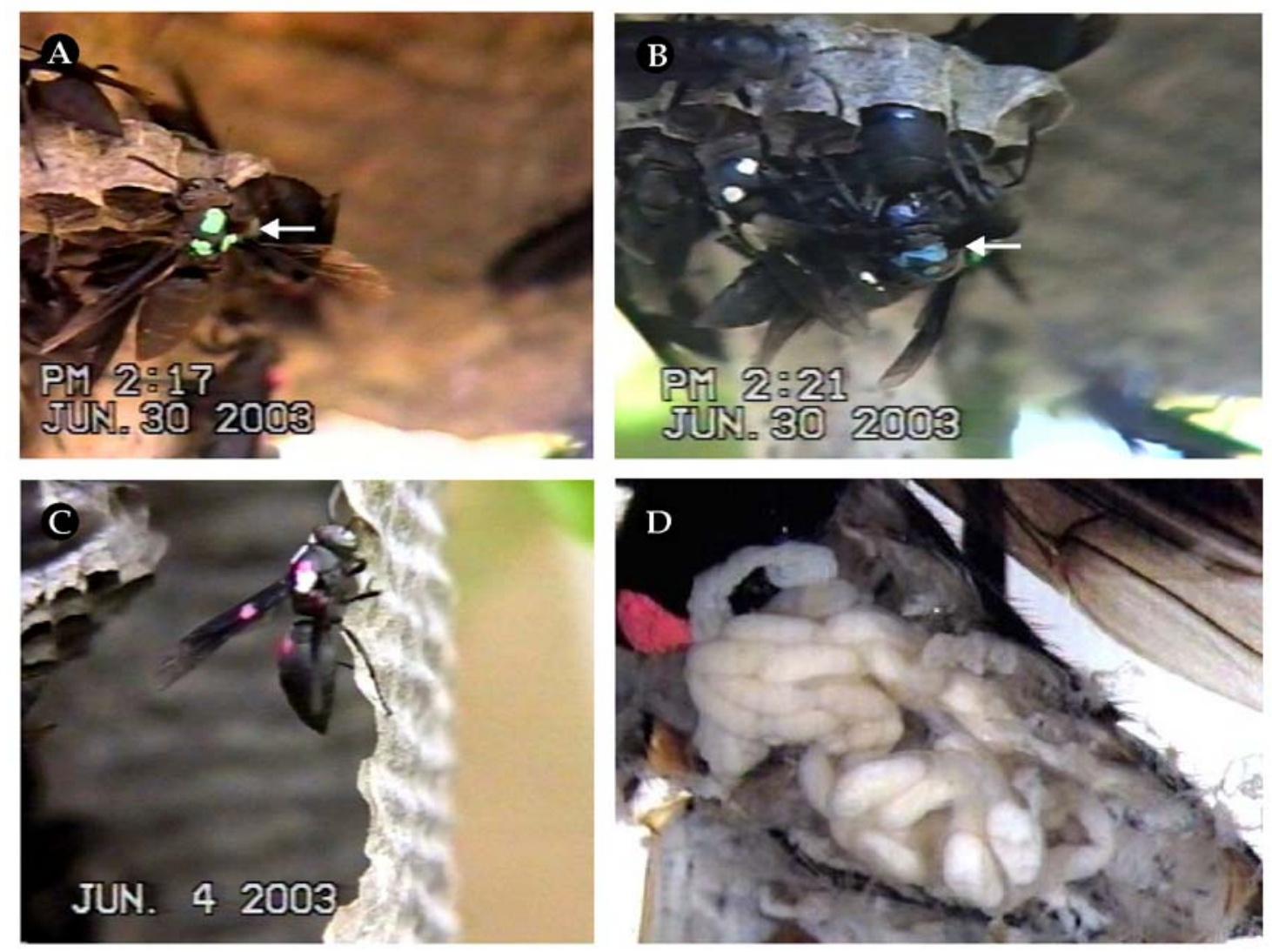

Figura 9. Fase de pós-estabelecimento da colônia C5: A - rainha código R3VD parada na borda do favo; B - intermediária durante postura; C - operária código 261 construindo invólucro durante a fase de produção de operárias; D - ovário da rainha substituta (operária código 261) coletada em 05/12/03 . 


\section{C.4 - CONSIDERAÇÕES SOBRE AS INTERAÇÕES ETOLÓGICAS}

\section{C.4.1 - Interações etológicas entre rainhas e intermediárias nas diferentes fases das colônias.}

Durante as observações sobre o comportamento das rainhas de $P$. fraternus nas colônias estudadas ficou evidente que seu principal papel é a realização de postura. Não exercem dominância explícita sobre as operárias ou sobre suas atividades na colônia. Em colônias estabilizadas (colônias C1, C2 e C5 fase de produção de operárias) é possível que as posturas das intermediárias possam ser inibidas em certas fases do ciclo colonial, via feromônio. As relações entre as castas são poucas e não antagônicas (amigáveis), porém isso depende da fase da colônia.

Nas colônias C1 e C2 durante o estabelecimento não foram observados atos agressivos entre operárias e rainhas. Entretanto, na colônia C2 durante o pós-estabelecimento as rainhas foram agredidas por operárias e gradativamente eliminadas. Na colônia C3 durante o estabelecimento rainhas foram agredidas e eliminadas por operárias, o mesmo foi observado na colônia C5. Nesta colônia a eliminação de rainhas iniciou durante o pré-enxameio e continuou durante o estabelecimento até que restasse apenas uma rainha na colônia.

O elenco comportamental construído somente para rainhas e intermediárias (ver Material e Métodos), diferiu entre colônias e entre fases do desenvolvimento das colônias. Na colônia C5 a rainha R3VD foi mais ativa que as demais realizando mais atos comportamentais. Alguns desses atos comportamentais ligados a postura e às interações que julgamos ser mais competitivos foram testados entre as rainhas e, separadamente, entre os indivíduos, não houve diferença estatisticamente significante. Apesar da rainha R3VD ter realizado mais atos comportamentais, e ter permanecido na colônia 
após a eliminação das outras rainhas, não houve diferença estatisticamente significante quando comparada com as outras rainhas.

Apesar de diferentes métodos de observação e de análises dos resultados citaremos os resultados obtidos em diferentes espécies estudadas por vários autores. Em Protopolybia acutiscutis (citada como pumila), as relações entre rainhas e operárias são amigáveis (Naumann, 1970); em Agelaia (= Stelopolybia) pallipes e Protopolybia exigua exigua, as poucas relações existentes entre rainhas e operárias são amigáveis, tendo (Simões, 1977) observado apenas um caso onde uma operária empurrou com a cabeça a rainha para fora do favo. Rainhas de Pa. colobopterus também interagem pouco com os membros da colônia e não exercem dominância explícita sobre as operárias (Herman et al 2000). Entre rainhas de Metapolybia sp. e Polybia occidentalis as interações são amistosas, porém em Metapolybia sp. foi observado um caso de dominância física (Forsyth, 1978). Baio (2002) não observou atos agressivos em M. docilis e Pr. exigua exigua, mas destaca comportamentos de dominância de rainhas sobre as operárias nas duas espécies. Em Asteloeca ujhelyii as relações entre castas não são amistosas, e entre as rainhas existe dominância (Nascimento, 2003; Nascimento et al., 2004).

Entre as rainhas de $P$. fraternus foi observada competição por células para realização de postura principalmente durante o estabelecimento. $\mathrm{Na}$ fase seguinte, ou seja, durante o pós-estabelecimento da colônia, este comportamento foi atenuado. Outros autores não mencionam esta característica comportamental para as demais espécies estudadas. Provavelmente, isso não foi visualizado devido à arquitetura do ninho, número de rainhas nas colônias, ou escassez das observações.

O comportamento de fixar o ovo pelas rainhas foi observado em todas as fases do desenvolvimento das colônias, porém durante o estabelecimento ele foi mais competitivo, provavelmente, devido ao pequeno número de células existentes. Como todas as rainhas fixam os ovos nas células, este resultado sugere que é do interesse coletivo a proteção destes ovos para a produção da primeira geração. Este comportamento também foi observado quando as 
rainhas faziam inspeções em células dos vários favos existentes, porém não pareceu ser agressivo. De acordo com Naumann (1970), ovos de rainhas que não são fixados após a postura são comidos dentro de 40 e 100 minutos. Rainhas de $P$. fraternus sempre fixa o ovo imediatamente após a postura. Em Agelaia (=Stelopolybia) pallipes cujas rainhas apresentam relações amigáveis (Simões, 1977), foi observado comportamento semelhante. Em Asteloeca ujhelyii este comportamento foi considerado como competição ritualizada (Nascimento, 2003; Nascimento et al., 2004). As rainhas após a postura sempre fixavam o ovo, por exemplo, na colônia $\mathrm{C} 1\left(\mathrm{n}^{\mathrm{o}}=32\right)$, a duração média deste comportamento foi de 42,37 \pm 19,05 seg. e, em seguida, deixavam a célula. Assim sendo, elas não ficavam de guarda ou na frente da célula protegendo o ovo como observado em Pr. acutiscutis (Naumann, 1970), e em Metapolybia azteca (West-Eberhard, 1973). Nesse caso, em uma colônia monogínica a rainha ficou em frente à célula de 2 a 3 minutos e, em colônias poligínicas, entre 12 e 17 minutos. Provavelmente o comportamento de proteger o ovo botado relaciona-se com a competição por células para oviposição e com a oofagia que é comum em colônias de Metapolybia sp. e Polybia occidentalis (Forsyth, 1978).

Nas colônias de P. fraternus estudadas não foi detectado qualquer tipo de territorialidade entre as rainhas, uma vez que elas realizaram posturas, inspeção de células e fixaram ovos em todos os favos. De acordo com Simões (1977), não foi detectado territorialidade em Agelaia (=Stelopolybia) pallipes e Pr. exigua exigua. Isso tudo é muito diferente de Bombus atratus onde, na fase poligínica, ocorrem vários territórios delimitados pelas rainhas. A invasão territorial causa conflitos e até a eliminação de indivíduos (Zucchi, 1973). Não foi observada também a formação de corte em torno de uma rainha, diferente das complexas interações observadas entre rainhas e operárias de Meliponinae e Apis (Zucchi, 1993, inclusive referências). 


\section{C.4.2 - Posturas das rainhas.}

Em $P$. fraternus as rainhas realizam posturas tão logo as primeiras células tomem a forma de uma taça rasa. Isso também ocorre em Metapolybia azteca e Pó. occidentalis (Forsyth, 1978), sendo diferente de outras espécies onde a oviposição é retardada até que a construção do ninho seja completada (Richards \& Richards, 1951; Evans \& Eberhard, 1970). A postura das rainhas de $P$. fraternus é um processo divido em três etapas, iniciando pela inspeção na célula a ser botada, a postura e a fixação do ovo, similar a demais espécie de Epiponini estudadas. Rainhas de Agelaia (= Stelopolybia) pallipes, Protopolybia exigua exigua, Pr. acutiscutis apresentam os mesmos padrões de postura (Simões, 1977; Naumann, 1970). Também o comportamento de postura das rainhas de Po. occidentalis e de Metapolybia é muito similar (Forsyth, 1978).

Em $P$. fraternus, não houve diferença estatisticamente significante na duração das posturas das rainhas ou entre as posturas observadas durante as fases do ciclo colonial. A duração média de postura das rainhas de Agelaia (= Stelopolybia) pallipes $(\mathrm{n}=31)$ foi de $105 \pm 17$ seg. e de Pr. exigua exigua $(\mathrm{n}=32)$ foi de $106 \pm 36,3$ seg. (Simões, 1977). A duração média de 56 posturas de $P$. fraternus foi de 55,77 $\pm 16,54$ segundos. A duração média para posturas de rainhas de Metapolybia docilis foi de $2.37 \pm 1.24$ seg. E 26 posturas de rainhas de Pr. exigua tiveram duração de 123,00 \pm 50,63 seg., (Baio, 2002). Entretanto, entre rainhas de diferentes espécies de Epiponini, não foi detectada variação significante na duração das posturas.

\section{C.4.3 - Oofagia pelas rainhas.}

Em colônias de Epiponini, relatos de oofagia feito por rainhas em ovos de outras rainhas são escassos, provavelmente, devido às dificuldades impostas pelos métodos de observação utilizados. No entanto a detecção desse fenômeno é importante por ser ele considerado competitivo (oofagia diferencial, 
Heldmann, 1936; Pardi, 1942; Gervet, 1964), uma vez que na verdade o que ocorre é a substituição do ovo (West-Eberhard, 1978b).

A oofagia realizada pelas rainhas de $P$. fraternus foi observada durante o estabelecimento e pós-estabelecimento na colônia C1. Na colônia C2 durante o pós-estabelecimento a oofagia coincidiu com o período em que as rainhas estavam sendo agredidas e eliminadas gradativamente da colônia, possivelmente perdendo a dominância feromonal. É possível que a oofagia diferencial ocorra com mais freqüência e que não esteja ligada a um período de escassez de alimento. Nesta fase da colônia (pós-estabelecimento) as células geralmente contêm ovos e imaturos, porém células vazias são encontradas devido à emergência de novos indivíduos ou larvofagia.

A constatação de oofagia permite supor que existe uma competição entre rainhas principalmente durante o pós- estabelecimento da colônia o que, neste estudo, coincidiu com o desaparecimento ou eliminação de algumas rainhas. Durante o patrulhamento pelos favos as rainhas inspecionam dezenas de células e certamente reconhecem os ovos botados por outras rainhas. Estes podem ser comidos e substituídos e, desta forma, as rainhas garantem a produção de um número maior de indivíduos altamente aparentados.

Estudo de glândulas exócrinas em Polistes fuscatus revelou que a glândula de "Dufour" e a glândula do quinto esternito nas fêmeas dominantes são maiores e aparentemente mais ativas. A secreção da glândula de "Dufour", provavelmente, adere ao ovo durante a postura, sendo provável, também que tem a função de comunicar o "status" da poedeira e de prevenir a oofagia feita por subordinadas durante período de intensa competição reprodutiva (Downing \& Jeanne, 1983). Outro fato relacionado pode ser a necessidade fisiológica de postura pelas rainhas. Como seus ovários sempre têm ovócitos maturos, em ninhos onde há poucas células vazias elas teriam que comer o ovo de outra rainha para botar seu ovo no lugar. De acordo com West-Eberhard (1969), as fêmeas dominantes são mais eficientes em procurar e destruir ovos das competidoras. Isto provavelmente está relacionado com a grande 
quantidade de ovos maturos em seus ovaríolos. No lugar de cada ovo comido, invariavelmente, a rainha bota outro no lugar.

Oofagia diferencial é bem distinta de oofagia nutricional, na qual o ovo é usado indiretamente para alimentar larva. De acordo com Baio (2002), as intermediárias de Pr. exigua exigua após a postura comem seu próprio ovo. Em seguida elas anda pelo favo fazendo contato bucal com larvas e, supostamente, estariam alimentando os imaturos. Quando a primeira larva de Polistes dominulus eclode ela é alimentada com ovos (Heldmann, 1936, Roseler \& Roseler, 1989). Esse comportamento também foi observado em Polistes (Strassmann et al, 1983). De acordo com Jeanne (1972), provavelmente ovos são usados como alimento para a primeira larva que eclode em ninhos de Mischocyttarus drewseni, quando presas não são encontradas. Fundadoras principais em algumas espécies de Polistes impedem a oofagia diferencial pelas fundadoras associadas ficando de guarda depois da postura (Starr, 1991). Numa colônia poligínica de Metapolybia aztecoides uma rainha ficou três horas protegendo seu ovo (West-Eberhard, 1981, 1982). Esse comportamento difere muito das rainhas de $P$. fraternus. Durante os primeiros estágios de uma associação de fundadoras de Polistes, e antes da regressão dos ovários das auxiliares, algumas fêmeas em posição hierarquicamente inferior, podem botar, porém estes ovos são reconhecidos e invariavelmente comidos pela fêmea dominante (West-Eberhard, 1969; Pardi, 1942, Pardi, 1946). Esse fenômeno foi denominado de "oofagia diferencial" (Heldmann, 1936; Pardi, 1942; Gervet, 1964). Em várias espécies de Polistes se observou uma evidente competição entre as fundadoras, pois, durante patrulha pelos favos, ovos das fundadoras são mutuamente destruídos (Starr, 1991). O mesmo fenômeno também foi observado em Mischocyttarus drewseni (Jeanne, 1972). Em todos os casos, obviamente, estão envolvidos conflitos de interesse genético. Rainhas de Vespinae, assim como muitas espécies de Epiponini, evidentemente, produzem feromônio que inibem a reprodução de poedeiras sem que seja necessária a 
inibição física (agressões) (West-Eberhard, 1977a; Jeanne, 1980a, Akre \& Reed, 1983).

O comportamento de oofagia diferencial, é amplamente utilizado em Vespinae e Polistinae e é, provavelmente, mais freqüente entre os Epiponini, pois sendo altamente competitivo ele se encaixa no contexto da "Kin Selection" como observado por West-Eberhard (1975): “A rainha esta preparada para impedir a substituição do seu ovo por outro menos aparentado".

\section{C.4.4 - Eliminação gradual de rainhas nas colônias C1 e C2.}

Durante os estudos, nas colônias C1 e C2, apenas as rainhas realizaram posturas. No estabelecimento não foram observados atos agressivos entre rainhas, entre operárias e rainhas ou entre as operárias. Na colônia C2 durante o pós-estabelecimento, rainhas começaram a ser agredidas por operárias 78 dias após o estabelecimento. Essas agressões causaram sérios danos nas asas das rainhas impossibilitando-as de voar.

Não se observou operárias testando as rainhas antes de atacar como foi observado em Metapolybia aztecoides (West-Eberhard, 1978) e em Asteloeca ujhelyii (Nascimento, 2003). As agressões ocorriam enquanto as rainhas andavam pelos favos, ou quando faziam solicitação de alimento às operárias.

No entanto, mesmo sendo atacadas algumas rainhas permaneceram na colônia e realizaram posturas. É interessante notar que novas rainhas foram observadas somente depois do desaparecimento da colônia das rainhas "velhas" (identificadas por marcas) que foram observadas por até 237 dias.

De acordo com nossos resultados, a produção ou aparecimento de novas rainhas ocorre somente quando a colônia está órfã ou quando há poucas rainhas. Dados afins foram relatados por outros autores (West-Eberhard, 1978b; Strassmann et al., 1991, 2002; Queller et al., 1993). 
Na colônia C1 não foi observada nenhuma agressão de operárias às rainhas, ou conflitos entre rainhas. Nesse caso, somente as rainhas foram observadas realizando posturas e, elas desapareceram da colônia gradativamente. Algumas delas foram observadas por até 166 dias após sua identificação no início dos estudos. É interessante notar que nas colônias C1 e C2 as intermediárias não fizeram posturas, o que difere das colônias C3 e C5. Isso permite concluir que estas duas colônias possivelmente já tinham produzido enxames e estavam estabilizadas. Mas, possivelmente, havia intermediárias na população o que é muito comum nesta espécie (Mateus et al., 2004). Devido ao número de rainhas ativas nas colônias, as intermediárias não se manifestaram, provavelmente, por estarem sendo inibidas pelas rainhas.

Em algumas espécies de Vespinae e de Polistinae há evidências de que as rainhas inibem as operárias da competição direta via produção de feromônio (West-Eberhard, 1977; Jeanne 1980; Spradbery, 1991). Em Pa. colobopterus foram observadas agressões de operárias à operárias com desenvolvimento ovariano o que pode indicar um mecanismo controlador, impedindo a reprodução destes indivíduos (Herman et al, 2000; Henshaw et al., 2000).

Conflitos genéticos entre os membros de uma colônia motivam a agressão de operárias velhas à operárias jovens que tentam se reproduzir (Platt et al, 2004). Quando a colônia ainda tem rainhas, as operárias provavelmente agridem outras fêmeas na tentativa de impedir a reprodução destas (Strassmann et al, 2002). Porém, fêmeas inseminadas com ovários desenvolvidos, em outras palavras, fêmeas ativas, não são envolvidas em agressões (Herman et al., 2000). Por outro lado, rainhas com ovários pouco desenvolvidos podem ser agredidas (Platt et al, 2004). Os resultados de Herman et al., (2000) e Strassmann et al, (2002) sugerem que estas agressões visam inibir algumas rainhas da colônia. Desde que as operárias são capazes de reconhecer sua linhagem materna dentro da colônia (Strassmann et al., 1997), provavelmente, elas inibem rainhas jovens impedindo-as de se tornarem rainhas ativas (Forsyth, 1978). Fêmeas com ovários desenvolvidos sofrem muitas agressões, principalmente quando jovens. Estas se não forem 
suprimidas podem produzir machos, se copularem produzirão fêmeas (Platt et al., 2004). Não é do interesse das operárias permitir novas fêmeas reprodutivas na colônia desde que tenha rainhas viáveis (Strassmann et al., 2002). Como exposto acima, possivelmente as colônias C1 e C2 estavam estabilizadas; não foram observadas novas rainhas ou intermediárias botando. Possivelmente as rainhas inibiram o aparecimento de novas poedeiras via produção de feromônio.

\section{C.4.5 - Eliminação de rainhas de forma abrupta na colônia C3.}

Na colônia $\mathrm{C} 3$ os ataques às rainhas iniciaram-se 4 horas após a migração da população para o local do novo ninho. Entretanto, em $P$. fraternus o ataque era precedido apenas por um breve reconhecimento com as antenas, possivelmente, identificavam os compostos das glândulas exócrinas das rainhas. É interessante notar que mesmo havendo dezenas de intermediárias na colônia elas não foram atacadas ou expulsas da colônia, diferente do que foi observado por Platt et al., (2004).

No entanto, uma evidência concreta e até então não observada em outras espécies de Epiponini indica que antes do início dos estudos, possivelmente, já estavam ocorrendo conflitos internos na colônia, pois no lado externo do invólucro fora construída uma pequena câmara que abrigava operárias e intermediárias. Segundo Platt et al., (2004), fêmeas com ovários desenvolvidos sofrem agressões principalmente quando jovens. De acordo com Strassmann et al., (2002), não é do interesse das operárias permitir novas fêmeas reprodutivas na colônia desde que tenha rainhas viáveis.

A colônia C3 estava na fase de produção de machos, esta é outra indicação de possíveis conflitos e seleção de rainhas. De acordo com os resultados de Mateus et al., (2004), colônias de P. fraternus durante a produção de machos têm um elevado número de intermediárias e rainhas, possivelmente, entre este elevado número de indivíduos com ovários desenvolvidos ocorram rainhas jovens e não inseminadas. 
A principal agressora de rainhas desta colônia (C3) desempenhou várias tarefas. Durante o pré-enxameio ela foi escoteira e construtora. No entanto, as causas que levaram este indivíduo a atacar somente rainhas durante $o$ estabelecimento são desconhecidas. O mesmo ocorreu na colônia C5, durante o pré-enxameio. Rainhas foram atacadas por uma única operária.

O comportamento de mordiscar outros membros da colônia pelas operárias foi observado na colônia C3 logo após a remoção das intermediárias e rainhas e, na colônia C5, no início da fase monogínica. De acordo com o padrão de ovário e idade relativa dos indivíduos envolvidos, este comportamento não se relaciona com o controle de posturas. Possivelmente relação com o elevado número de indivíduos inativos na população. Segundo O’Donnell (2001), agressão entre operárias de Po. occidentalis possivelmente seja um mecanismo regulador de tarefas dentro da colônia. Comportamento similar também foi observado em Po. aequatorialis, Po. emaciata, Po. sericea e Pa. colobopterus (Strassmann et al., 1997; O’Donnell, 2001). Por outro lado, operárias de Pa. colobopterus reduzem a agressão em fêmeas com ovários desenvolvidos quando não há rainhas na colônia, permitindo a estas se tornarem rainhas (Strassmann et al., 2002: Platt et al., 2004).

\section{C.4.6 - A orfandade da colônia C3.}

A orfandade na colônia C3 refletiu-se na arquitetura do ninho. O tubo de entrada típico desta espécie não foi construído, mas tão somente uma pequena abertura. Apesar de inúmeros ovos nas células não foram observados indivíduos com síndrome comportamental de rainha.

Durante o estabelecimento da colônia C3 foram coletadas 26 rainhas e 72 intermediárias, estes valores estão de acordo com a fase de produção de machos (Mateus et al., 2004) em que ocorre um alto número de intermediárias e, semelhante ao verificado por Noll (2000) e Baio (2002) para as espécies com baixa diferenciação entre as castas. Nas espécies com alta diferenciação entre as 
castas não foram encontradas rainhas virgens em colônias que continham machos (Baio, 2002, Nascimento, 2003).

Na ausência de rainhas foi observado um elevado número de indivíduos não jovens com ovários desenvolvidos $(37,5 \%$ do total), as quais, se inseminadas, tornar-se-iam rainhas substitutas, como observado na colônia C5. Este resultado também sugere que em colônias estáveis (colônias C1 e C2) as rainhas, provavelmente, via feromônios, inibem as posturas das intermediárias.

A falta de machos em ninhos próximos, provavelmente, contribuiu para a não inseminação das futuras rainhas, sendo possível que entre as intermediárias poderia haver rainhas jovens e não inseminadas, considerando que quando a colônia foi parcialmente destruída para provocar o enxameio, ela estava produzindo machos. Outra possibilidade seria a de que qualquer fêmea da colônia que possa desenvolver ovário em uma fase da vida, na presença ou ausência de rainhas, pode ser inseminada e tornar-se rainha "substituta", como foi comprovado na colônia C5. Em uma colônia de Pa. colobopterus após remover todas as rainhas e indivíduos tentando realizar posturas, após 7 dias confirmou-se o aparecimento de uma rainha inseminada (Strassmann et al., 2002).

\section{C.4.7 - Eliminação de rainhas de forma abrupta na colônia C5.}

Pouco se conhece sobre os métodos de controle de rainhas ou inibição da reprodução entre as vespas enxameadoras (Jeanne, 1991; Spradbery, 1991). Segundo West-Eberhard (1977), rainhas de Metapolybia aztecoides são reconhecidas pelos demais membros da colônia. Presumivelmente, o reconhecimento é feito através de glândulas exócrinas localizadas na cabeça. $\mathrm{O}$ que podemos supor é que a rainha R3VD não foi atacada por operárias por ser 
feromonalmente reconhecida como a mais fértil ou dominante entre as demais rainhas.

As rainhas atacadas e eliminadas estavam ativas durante as fases anteriores, uma vez que realizaram posturas e interagiram com os demais membros da colônia, não tendo sido observadas agressões a elas. Além disso, elas tinham ovários desenvolvidos com muitos ovócitos maturos. Estes resultados diferem do que foi observado por Platt et al., (2004) e Hermann et al., (2000). Em Parachartegus colobopterus rainhas ativas e com ovários desenvolvidos não se envolveram em agressões, embora estes autores não mencionem as fases das colônias estudadas.

A fase de estabelecimento da colônia C5 iniciou-se com 5 rainhas. Curiosamente, durante o pré-enxameio algumas delas foram alvo de agressões feitas por uma operária. Durante os 6 primeiros dias do estabelecimento todas as rainhas presentes na colônia realizaram posturas, e as interações entre elas foram amigáveis. Essas rainhas tiveram que competir com várias intermediárias. Durante este período inicial do estabelecimento, a rainha R3VD foi mais ativa que as demais.

O número de células construídas durante os primeiros dias foi baixo. Diferentemente do que foi observado em outras colônias, foram observadas poucas forrageadoras de polpa e havia dezenas de operárias inativas na colônia. Provavelmente, devido a este fato, houve muita competição por células para postura e foram observadas várias oofagias feitas por intermediárias. No sétimo dia de estabelecimento, a rainha R3VD apresentou mudança radical no comportamento, provavelmente, devido à alta competição que estava ocorrendo entre as rainhas e intermediárias presentes na colônia. A partir desta mudança no comportamento da rainha R3VD as demais rainhas não foram mais observadas, uma vez que se refugiaram em folhas e galhos próximos do ninho. No entanto, as intermediárias continuaram na colônia e não foram agredidas. 
O comportamento de mordiscar foi mais intenso após a expulsão das rainhas, principalmente, para com as operárias inativas sob o invólucro. Estes resultados diferem do que foi observado por (Strassmann et al, 2002; Platt et al., 2004), e tem mais relação com as observações de O’Donnell (2001), ou seja, agressão entre operárias de Polybia occidentalis e P. fraternus, possivelmente, é um mecanismo de regular as tarefas dentro da colônia.

Em outras espécies de Epiponini estudadas nunca foi observada rainha eliminando rainha via agressão direta. Mas a rainha R3VD agrediu uma das rainhas quando esta retornou ao ninho, mordeu-a e prendeu-a pela base das asas. Logo as operárias também participaram da agressão. Nos dias que se seguiram a rainha R3VD deslocou-se muito agitada pela colônia, tocando os indivíduos, mordiscando e fazendo muita solicitação de alimento. Provavelmente este comportamento de patrulha é uma forma de controlar a presença de outras rainhas na colônia. Certamente uma rainha deve reconhecer outras rainhas devido aos produtos das glândulas exócrinas que provavelmente exalam diferentes odores em relação aos indivíduos não inseminados. A rainha só voltou à normalidade de seu comportamento quando as rainhas eliminadas que estavam próximas do ninho foram coletadas. Provavelmente, ela conseguia perceber a proximidade destas rainhas.

De acordo com alguns autores, as operárias são as principais responsáveis pela eliminação das rainhas inviáveis da colônia (West-Eberhard, 1978a; Forsyth, 1978, Hermann et al., 2000, Platt et al., 2004). As rainhas são às vezes perseguidas por outras rainhas até fora do favo, mas agressão ou ataque entre rainhas nunca foi observado (West-Eberhard, 1978a; Jeanne, 2003). Segundo Nascimento (2003) e Nascimento et al., (2004), em Asteloeca ujhelyii a solicitação agressiva das operárias e a competição reprodutiva entre as rainhas têm papel fundamental na redução no número de rainhas, ocasionando a monoginia funcional. Como não existe diferenciação morfológica de tamanho que favoreça as rainhas, ficou evidente que as rainhas perdem a "dominância química“ ao longo do ciclo. Isso pode, também, estar relacionado com a idade 
do indivíduo. Portanto em P. fraternus as rainhas agredidas fisicamente por operárias, são eliminadas do ninho.

Strassmann et al., (2002) confirma o que foi observado por West-Eberhard (1978a), isto é, devido à agressão de operárias algumas rainhas voltam a desempenhar tarefas de operárias. Infelizmente estes autores não mencionam se estes indivíduos estavam inseminados. Como em Parachartergus colobopterus não foi possível diferenciar uma rainha de uma operária dentro da colônia (Strassmann et al., 2002), pode estar havendo confusão entre rainha e intermediária.

Essas últimas afirmações não foram confirmadas em $P$. fraternus. Somente rainhas verdadeiras foram perseguidas e eliminadas do ninho de forma gradual ou são atacadas e expulsas da colônia por rainha e operárias. Jamais foi observada uma rainha verdadeira fazendo tarefa de operária. Constatamos entretanto, que as intermediárias da colônia C5 realizaram tarefas de operárias na fase anterior ao estabelecimento da colônia. Em colônias de Parachartergus smithii, por exemplo, em um mesmo intervalo de observação as intermediárias realizaram posturas e construíram invólucro ou maceraram polpa vegetal (S. Mateus não publ.).

\section{C.4.8 - Substituição da rainha na colônia C5.}

Na colônia C5 foi observado um caso autêntico de substituição da rainha por uma operária. A fêmea que se tornou rainha substituta foi observada por 192 dias, pois, quando foi constatada a orfandade da colônia, fazia 179 dias que ela tinha recebido o código de cores. Não era, portanto, um indivíduo jovem.

Esta fêmea foi observada realizando diversas tarefas ligadas à construção e manutenção da colônia. Essa rainha substituta deve ter copulado com macho da própria colônia, pois não ocorre esta espécie na área de estudos. Durante o estabelecimento esta fêmea não se manifestou como intermediária. Além disso, durante a fase monogínica, supostamente, a mais provável candidata a se tornar 
rainha substituta seria uma das intermediárias que restavam no ninho. Infelizmente não sabemos como aconteceu esta substituição, pois a colônia não estava sendo intensamente observada. Para uma fêmea comum, esta é uma idade relativamente alta. Simões (1977) constatou que a idade média de operárias de Pr. exigua exigua foi de 25,60 \pm 16,80 dias, e de A. (=Stelopolybia) pallipes de 21,94 \pm 8,5 dias. Rainhas de Pr. exigua exigua foram observadas até 377 dias de idade.

Strassmann et al., (2002) estudando Pa. colobopterus, chamaram de totipotência o aparecimento de uma fêmea inseminada após uma semana de remoção de todos os indivíduos que estavam realizando posturas na colônia. Não havia machos na colônia estudada. Em Pa. smithii foi observado uma operária tornar-se rainha substituta após o desaparecimento da única rainha da colônia (S. Mateus, não publ.). Em P. fraternus e, provavelmente, em outras espécies com baixa diferenciação morfológica entre as castas, onde a determinação de casta rainha é pós-ímaginal, todas as operárias teriam a possibilidade de se tornar rainha dentro de uma determinada faixa etária, pois todas podem desenvolver os ovários durante um período da vida. No entanto rainhas verdadeiras são produzidas na colônia e, de acordo com Queller \& Strassmann (1998) e Strassmann et al., (2002) a determinação não é genética e sim ambiental (pós-imaginal). Por outro lado se o indivíduo já nasce rainha, provavelmente, ela jamais se tornará uma operária como observado por (WestEberhard, 1978a; Herman et al, 2000; Strassmann, 2002, Platt et al, 2004).

As intermediárias presentes nas colônias C3 e C5 durante a eliminação de rainhas não foram agredidas, estes resultados diferem parcialmente do que foi observado por Platt et al., (2004) pois, conforme relatado, fêmeas com ovários desenvolvidos sofrem agressões principalmente quando são jovens. 


\section{C.4.9 - Sobre a identidade das intermediárias.}

As intermediárias são encontradas principalmente nas espécies de Epiponini onde a diferenciação entre as castas é pós-imaginal, e onde as diferenças morfológicas entre rainhas e operárias são quase inexistentes (Richards, 1971, 1978; Noll \& Zucchi, 2000, Noll et al., 1996, 2002, 2005; Baio, 2002; Mateus et al., 1997, 1999, 2004), síndrome Chartergellus (Noll, 2000; Noll et al., 2003). De acordo com Richards (1971) e Naumann (1970), as intermediárias podem ser produtoras de machos ou de ovos nutritivos; outros autores consideraram como sendo rainhas jovens e não inseminadas (Forsyth, 1978; West-Eberhard, 1978a; O`Donnell, 1998). Entretanto, temos que levar em conta qual é o tipo de diferenciação encontrada nas espécies mencionadas por estes autores, rainhas virgens raramente são distinguíveis de intermediárias, principalmente, nas espécies com baixa diferenciação entre as castas.

De acordo com os resultados de Simões (1977) e Baio (2002), intermediárias de Pr. exigua apresentam polietismo etário, onde além de botar ovos desempenham outras funções dentro da colônia. Em Meliponinae, na maioria das espécies, as operárias dentro de uma determinada faixa etária produzem ovos tróficos que são ingeridos principalmente pela rainha (Zucchi, 1993).

Neste trabalho, tivemos a oportunidade de conhecer um pouco mais sobre a identidade das intermediárias, que na espécie estudada, estão presentes em todas as fases do ciclo colonial e, às vezes, em maior número que rainhas (Mateus et al., 2004). Durante o pré-enxameio da colônia C3 havia algumas intermediárias entre as escoteiras que, posteriormente, foram observadas construindo invólucro e forrageando. A principal agressora de rainhas observada durante o estabelecimento foi uma escoteira. Durante o estabelecimento, também construiu invólucro e macerou polpa vegetal.

Na colônia C5 durante a fase de produção de operárias as intermediárias foram observadas realizando tarefas ligadas principalmente à construção do 
ninho, interação com adultos e cuidados com a prole. Diferente do que foi observado por Strassmann et al., (2002), as intermediárias não eram jovens.

As intermediárias que foram coletadas durante a postura não estavam inseminadas, portanto, não eram rainhas inibidas que estiveram realizando funções de operárias na fase anterior, como afirma West-Eberhard (1978) e Strassmann et al., (2002).

Estes resultados sugerem que em $P$. fraternus, possivelmente, existe polietismo etário, fêmeas com ovários desenvolvidos desempenham diferentes tarefas dentro da colônia, como observado em intermediárias de Pr. exigua exigua (Simões, 1977; Simões \& Zucchi, 1980; Baio, 2002). Entretanto, em situações como uma migração forçada, possivelmente ocorre uma mudança nas tarefas devido à urgência em atender as necessidades primárias da colônia.

A postura de ovos pelas intermediárias parece ser facultativa e oportunista. Durante o estabelecimento e pós-estabelecimento da colônia C5 as intermediárias não foram impedidas de botar. O mais interessante é que na fase de produção de operárias não se comportaram como intermediária, isto é, não botaram ovos. Provavelmente elas já tinham os ovários desenvolvidos, e devido ao número de rainhas presentes na colônia foram suprimidas por feromônios das rainhas. É preciso enfatizar que não foram observados atos agressivos sobre estes indivíduos durante a fase de produção de operárias da colônia, o que sugere ausência de operárias fazendo qualquer tipo de controle sobre elas. Durante o estabelecimento, suas atividades estiverem exclusivamente ligadas à postura, não foram observadas realizando funções de construtoras, competiram com as rainhas, botaram na presença das rainhas e realizaram oofagia em ovos de rainhas e de intermediárias.

De acordo com os resultados de Simões (1977), é possível que todas as operárias de Pr. exigua exigua, desenvolvam seus ovários numa determinada fase do seu ciclo de vida. Porém, como o autor não cita ter observado oofagia, ele sugere que deve ocorrer oofagia diferencial, pois é baixo o número de machos observado nas colônias. Outras observações (Baio, 2002) relatam postura e oofagia pela própria poedeira (auto-oofagia) em Pr. exigua. Em Agelaia (=Stelopolybia) pallipes os ovários das operárias não se desenvolvem (Simões, 
1977). Operárias de Pr. acutiscutis foram observadas realizando postura, entretanto, sempre após a postura comia o próprio ovo; é possível que em certas ocasiões estes ovos eram permitidos desenvolver-se produzindo machos, porém não é conhecida a origem dos machos nesta espécie, segundo Naumann, 1970, também podem ser produzidos por rainhas velhas durante a produção de novas rainhas. De acordo com Hastings et al., (1998) e Henshaw et al., (2000), machos são todos ou quase todos produzidos pelas rainhas.

Mas é preciso ressaltar que em Protopolybia e Agelaia a diferenciação entre as castas é pré-imaginal, intermediária é uma operária com ovário desenvolvido dentro de uma determinada faixa etária, diferente de $P$. fraternus em que intermediária pode tornar-se rainha em colônias órfãs.

A duração das posturas de intermediárias e de rainhas de $P$. fraternus (colônia C5) não foram estatisticamente diferentes. Algumas intermediárias ficaram protegendo o ovo após a postura por até 20 minutos o que diferiu do comportamento das rainhas que não protegeram seus ovos após a postura. Em uma colônia poligínica de $M$. aztecoides uma rainha foi observada por três horas protegendo seu ovo (West-Eberhard, 1981, 1986). A duração das posturas das intermediárias de Pr. exigua foi de 49,83 $\pm 25,05 \mathrm{seg}$. (n=18), e das rainhas foi de $123,00 \pm 50,63$ seg. ( $n=26$ ), diferença estatisticamente significante (Baio, 2002). Para a mesma espécie, Simões (1977) observou uma diferença significativa na duração de posturas de rainhas e intermediárias.

Estes resultados sugerem que as intermediárias de $P$. fraternus, na fase de estabelecimento, realizaram oofagia diferencial e possivelmente podem ser rainhas não inseminadas. Não houve diferença na duração da postura quando comparado com postura de rainhas, no entanto, não apresentaram síndrome comportamental de rainha.

Para as espécies onde a determinação de castas é pré-imaginal, fêmeas com ovários desenvolvidos e capazes de botar são consideradas armazenadoras de energia (Simões, 1977; Naumann, 1970; Shima et al., 1998). Estudos sobre o polietismo etário de $\mathrm{Pr}$. exigua exigua mostrou que as intermediárias botam ovos freqüentemente, e a fase de postura ocorre na classe de idade entre 6 e 30 dias, além de outras atividades que estes indivíduos estão envolvidos (Simões, 1977; Simões \& Zucchi, 1980). Em P. colobopterus machos são produzidos principalmente pelas rainhas, somente uma pequena fração é produzida por operárias, neste caso intermediárias (Henshaw et al., 2000). Em Brachygastra 
mellifica é alto o número de operárias com ovários desenvolvidos, provavelmente ocorre oofagia diferencial e os machos são todos ou quase todos produzidos pelas rainhas (Hastings et al., 1998). 


\section{D - CONCLUSÕES}

A partir dos resultados obtidos neste estudo pode-se concluir:

Os comportamentos observados em $P$. fraternus durante o pré-enxameio e migração foram semelhantes entre as colônias estudadas, e semelhante em alguns aspectos quando comparado com outras espécies de Epiponini.

As escoteiras de $P$. fraternus iniciam a busca pelo novo local do ninho logo após a destruição do ninho original. A população permaneceu no local do ninho original por um período variável. Após a escolha de um local para construir o novo ninho e a confecção do caminho químico, o sinal de partida é dado pelas escoteiras.

As escoteiras fazem o caminho químico usando principalmente folhas como substrato, nelas esfregam o abdômen deixando uma marca química. $P$. fraternus tem apenas glândulas da classe I nos esternitos gastrais, mas o caminho químico feito pelas escoteiras entre o ninho original e o novo local do ninho foi muito eficiente, não houve perda de indivíduos da população, exceto duas rainhas e os machos que não acompanham os enxames.

As escoteiras utilizam veneno para marcar o local do novo ninho e também para marcar o ponto final da migração; provavelmente o veneno também é utilizado para fazer o caminho químico associado com outros produtos glandulares.

A migração da população é difusa mas o deslocamento é massal; não ocorre formação de agrupamentos temporários como observado em outras espécies de Epiponini.

Em $P$. fraternus as primeiras coletas de polpa vegetal para a construção do novo ninho ocorre no ninho original antes da migração da população; são feitas por escoteiras que selecionaram o novo local do ninho e continuam após a migração. 
As escoteiras estão entre as operárias mais velhas da população, são flexíveis na realização de diversas tarefas antes e depois da migração, são capazes de forragear material de construção e água e de construir invólucro e favos. Entre as escoteiras da colônia C3 havia uma intermediária que realizou postura.

As rainhas permanecem no ninho original até o momento da migração. Raramente deixam o ninho. Foram observadas curvando o abdômen entre elas e para as operárias, fizeram solicitação de alimento para operárias.

A distância da migração, provavelmente, não tem relação com o tamanho da população e nem com o tamanho da área de forrageio. Possivelmente, a distância da migração está relacionada com a disponibilidade de substratos para nidificação e de recursos.

Durante o pré enxameio, após a remoção das estruturas dos ninhos, as forrageadoras de $P$. fraternus coletaram presas, isto mostra que os adultos também utilizam proteína animal como alimento.

As interações etológicas entre as rainhas, intermediárias e operárias foram geralmente amistosas, porém, isso parece depender da fase da colônia. Não foi detectado qualquer tipo de territorialidade entre as rainhas.

A postura das rainhas de $P$. fraternus é divida em três etapas, inspeção da célula, a postura e a fixação do ovo, similar as demais espécies de Epiponini estudadas. Não foi detectada diferença estatisticamente significante na duração das posturas das rainhas, nem mesmo diferenças entre as posturas ocorrendo nas diferentes fases do ciclo colonial.

As interações competitivas entre as rainhas e entre rainhas e intermediárias foram evidentes, principalmente, durante o estabelecimento das colônias.

A constatação de oofagia diferencial feita por rainhas em ovos de rainhas é importante por ser ela considerado altamente competitiva. Este fenômeno foi observado também durante o período em que algumas rainhas estavam sendo agredidas. Assim, podemos supor que algumas rainhas, possivelmente, perdem a dominância feromonal. 
Foi constatada a eliminação gradual de rainhas nas colônias C1 e C2 durante os estudos. Na colônia C1 não foi observada agressão às rainhas. No entanto, na colônia C2 as rainhas foram agredidas por operárias que danificaram suas asas seriamente ficando elas incapazes de voar. As rainhas permaneceram na colônia realizando atos comportamentais ligados à postura mesmo sendo agredidas. Não foram observadas posturas de intermediárias. Novas rainhas somente foram vistas realizando posturas após o desaparecimento ou eliminação das rainhas marcadas. Rainhas marcadas foram observadas por até 237 dias.

A eliminação de rainhas na colônia C3 ocorreu durante o estabelecimento e, no caso, uma única operária foi a principal agressora. Os ataques foram exclusivamente direcionados as rainhas. $\mathrm{O}$ ataque era precedido de um breve reconhecimento com as antenas, possivelmente, a agressora identificava os compostos das glândulas exócrinas das rainhas. No entanto, evidências concretas mostraram que já estava ocorrendo conflito interno na colônia. Do lado externo do invólucro fora construída uma câmara que abrigavam intermediárias (prováveis futuras rainhas) e algumas operárias.

A colônia C3 ficou órfã após a remoção das rainhas e intermediárias em postura. A orfandade da colônia refletiu-se na arquitetura do ninho, não sendo construído o tubo de entrada típico da espécie, mas, somente uma pequena abertura. O comportamento de mordiscar outros membros da colônia pelas operárias foi observado após a remoção das rainhas e intermediárias. De acordo com o padrão de ovário e a idade relativa dos indivíduos envolvidos não se obteve relação com o controle de posturas. Quando a colônia foi coletada não havia rainhas, porém, foi encontrado um grande número de intermediárias.

Na colônia C5 a eliminação de rainhas iniciou-se durante o préenxameio e continuou durante o estabelecimento. As agressões durante o préenxameio foram feitas por uma única operária, porém, nesta colônia uma rainha também participou da agressão e eliminação de outra rainha. Durante o estabelecimento as intermediárias realizaram posturas e competiram com as 
rainhas por célula para postura, fizeram oofagia em ovos de rainhas e intermediárias. Não foram observados atos agressivos direcionados às intermediárias. Na fase monogínica a convivência entre castas foi pacifica até onde observamos.

Na colônia C5 uma operária tornou-se rainha substituta. Esta fêmea foi observada por 192 dias. Ela realizou tarefas ligadas à construção e manutenção da colônia nas diferentes fases estudadas. Porém, não foi observada realizando posturas. Essa rainha copulou com macho da própria colônia, pois não ocorre esta espécie na área de estudos.

Intermediárias foram observadas nas colônias C3 e C5 durante o estabelecimento. Durante o pré-enxameio da colônia C3 elas foram escoteiras e, posteriormente, foram observadas realizando posturas e tarefas ligadas à construção do ninho. Na colônia C5, durante a fase de produção de operárias, elas estiveram ligadas a tarefas de construção do ninho, interação com adultos e forrageio. No entanto, durante o estabelecimento realizaram posturas e fizeram oofagia.

Ficou evidente a competição entre as intermediárias e rainhas para realização de posturas na fase de estabelecimento. Não foram observadas agressões direcionadas as intermediárias, tampouco foram impedidas de botar. Provavelmente, na fase anterior, elas foram inibidas por feromônios produzidos pelas rainhas. Algumas delas foram observadas por até 102 dias após receber a identificação por cores. 


\section{E - REFERÊNCIAS BIBLIOGRÁFICAS}

Akre, R. D. \& Reed, H. 1983. Evidence for a queen pheromone in Vespula (Hymenoptera: Vespidae). Can. Entomol. 115: 371-377.

Anderson, C. \& Ratnieks, F. L. W. 1999. Task partitioning in insect societies. I. Effect of colony size on queueing delay and colony ergonomic efficiency. American Naturalist. 154: 521-535.

Baio, M. V., Noll, F. B., Zucchi, R. \& Simões, D. 1998. Non-allometric caste differences in Agelaia vicina (Hymenoptera, Vespidae, Epiponini). Sociobiology 32 (3): 465476.

Baio, M. V. 2002. Diferenciação de castas e aspectos relacionados ao ciclo colonial de algumas vespas do Brasil. (Hymenoptera, Vespidae, Epiponini). Dissertação de Doutorado, Departamento de Biologia, FFCLRP-USP. Ribeirão Preto SP. - USP, $125 \mathrm{p}$.

Bourke, A. F. G. 1999. Colony size, social complexity and reproductive conflict in social insects. J. Evol. Biol. 12: 245-257.

Bouwma, P. E., Bouwma, A. M. \& Jeanne, R. L. 2000. Social wasp swarm emigration: males stay behind. Ethology Ecology \& Evolution 12: 35-42.

Bouwma, A. M., Bouwma, P, E., Nordheim, E. V., \& Jeanne, R. L. 2003. Adult mortality rates in young colonies of a swarm-founding social wasp (Polybia occidentalis). Jour. Zool. 260: 11-16.

Brockmann, H. J., \& Dawkins, R. 1979. Joint nesting in a digger wasp as an evolutionary stable preadaptation to social life. Behaviour 71: 203-245.

Carpenter, J. M. 1982. The phylogenetic relationships and natural classification of Vespoidea. (Hymenoptera). Syst. Entomol. 7: 11-38.

Carpenter J. M. 1991. Phylogenetic relationships and the origin of social behavior in the Vespidae. In: The Social Biology of Wasps (K.G. Ross \& R.W. Matthews, Eds.), Cornell University Press, Ithaca, NY. 7-32 pp.

Carpenter, J. M. 1993. Biogeographic patterns in the Vespidae (Hymenoptera): Two views of Africa and South America. In P. Goldblatt (editor), Biological relationships between Africa and South America, pp. 139-155. New Haven, CT: Yale University Press, ix $+630 p p$.

Carpenter, J. M. 2004. Symonymy of the Genus Marinbonda Richards, 1978, with Leipomeles Möbius, 1856 (Hymenoptera: Vespidae: Polistinae), and a New Key to the Genera of Paper Wasps of the New World. American Museum Novitates. Number 16. 16 pp.

Carpenter, J. M. \& Rasnitsyn, A. P. 1990. Mesozoic Vespid. Psyche 97: 1-20. 
Castellón, E. G. 1982. Comportamento e causas da migração de Synoeca surinama L. (Hymenoptera, Vespidae), na Amazônia Brasileira. Revta. Bras. Ent. 26(1): 71-74.

Chadad, R. 1979. Early warming cues for social wasps attacked by army ants. Psyche 86: $115-123$.

Downing, H. A. \& Jeanne, R. L. 1983. Correlation of season and dominance status with activity of exocrine glands in Polistes fuscatus (Hymenoptera: Vespidade). Jour. Kansas Entomol. Soc. 56: 387-397.

Downing, H. A. \& Jeanne R. L. 1985. Communication of status in the social wasp Polistes fuscatus (Hymenoptera: Vespidade). Z. Tierpsychol. 67: 78-96.

Downing, H. A., 1991. The function and evolution of exocrine glands. In: The Social Biology of Wasps (K.G. Ross \& R.W. Matthews, Eds.), Cornell University Press, Ithaca, NY. pp. 540-569.

Drumond, M. S. 1986. Aspectos bionômicos e eto-evolutivos da Vespa Zethus (Zethoides) miniatus Saussure, 1858 (Hymenoptera, Eumenidae). Dissertação de Mestrado, FFFCLRP - USP. Departamento de Biologia, 159 p.

Ducke, A. 1906. Sobre as vespidas sociaes do Pará (1º Supplemento.). Boletim do Museu Goeldi 3: 652-698.

Evans, H. E. \& West-Eberhard, M. J. 1970. The Wasps. University Michigan Press, Ann. Arbor, Michigan. 265pp.

Ezenwa, V. O., Henshaw, M. Queller, D. C. \& Strassmann, J. E. 1998. Patterns of buzz running, a swarm initiation behavior, in the neotropical wasp, Parachartergus colobopterus, Insectes Sociaux, 45: 445-455.

Fagen, R. M. \& Goldman, R. N. 1977. Behavioral catalogue analysis methods. Animal Behaviour 25: 261-274.

Francescato, E., Turillazzi, S., \& Dejean, A. 1993. Swarming behaviour in Polybioides tabidus (Hymenoptera: Vespidae). Actes Coll. Insectes Soc. 8: 121-126.

Francescato, E., Bandini Tosi, A., \& Turillazzi, S. 1994. Caste dimorphism in Polybioides tabidus and raphigastra. Abstracts of the $12^{\text {th }}$ Congress International Union for the Study of Social Insects, p. 424. Paris, Sorbone.

Forsyth, A. B. 1978. Studies on the behavioral ecology of polygynous social wasps. Ph. D. Dissertation, harvard. University, 226p.

Forsyth, A. B. 1981. Swarming activity of polybiine social wasps (Hymenoptera: Vespidae: Polybiini). Biotropica. 13 (2): 93-99.

Gastreich, K. R., Strassmann, J. E. \& Queller, D. C. 1993. Determinants of high genetic relatedeness in the Swarm-founding wasp, Protopolybia exigua. Ethol. Ecol. and Evol. 5: 529-539. 
Gervet, J. 1964. Le comportment d' oophagie différentielle chez Polistes gallicus L. (Hymen. Vesp.). Insectes Soc. 11: 343-382.

Hamilton, W. D. 1963. The evolution of altruistic behavior. Amer. Nat 97: 354-356.

Hamilton, W. D. 1964a. The genetical evolution of social behaviour I. 3. Theor. Biol. 7: $1-16$

Hamilton, W. D. 1964b. The genetical evolution of social behaviour I. J. Jheor. Biol. 7: $17-52$

Hamilton, W. D. 1972. Altruism and related phenomena, mainly h the social insects. Annu. Rev. Ecol. Syst. 3: 193-232.

Hansel, M. H., Samuel, C. \& Furtado, J. I. 1982. Liostenogaster fiavolineata: social life of the small colonies of an Asian tropical wasp: Proc. Ninth. Congr. IUSSI. Boulder, Colorado, 192-195 pp.

Hastings, M. D. Queller, D. C., Eischen, F., \& Strassmann, J. E. 1998. Kin selection, relatedness and worker control of reproduction in a large-colony Epiponine wasp, Brachygastra mellifica. Behavioral Ecology 9 (6): 573-581.

Heldmann, G. 1936. Über das Leben auf Waben mit mehrerem überwinterten Weibchen von Polistes gallica L. Zentralbl. 56: 389-400.

Henshaw, M. J., Strassmann, J. E., Quach, S. Q. \& Queller, D. C. 2000. Male production in Parachartegus colobopterus, a neotropical, swarm-founding wasp. Ethology, Ecology and Evolution, 12: 161-174.

Herman, R. A., Queller, D. C. \& Strassmann, J. E. 2000. The role of queens in colonies of the swarm-founding wasp Parachartegus colobopterus. Animal Behaviour, 59: 841848.

Hölldobler, B. \& Wilson, E. O. 1977. The number of queens: an important trait in ant evolution. Naturwissenchaften 64: 8-15.

Howard, K. J., Smith, A. R., O’Donnell, S., \& Jeanne, R. L. 2002. Novel method of swarm emigration by the epiponine wasp, Apoica pallens (Hymenoptera: Vespidae). Ethology Ecology and Evolution 14: 365-371.

Hughes, C. R., Queller, D. C., Strassmann, J. E., Solis, C. R., Negrón-Sotomayor, J. A. \& Gastreich, K. R. 1993. The maintenance of high genetic relatedness in multi-queen colonies of social wasps. In: Queen Number and Sociality in Insects (L. Keller, Ed.), Oxford University Press, Oxford. pp. 153-170.

Hunt J. H., Jeanne R. L. \& Keeping M. G. 1995. Observations on Apoica pallens, a nocturnal Neotropical social wasp (Hymenoptera: Vespidae, Polistinae, Epiponini). Insectes Sociaux. 42: 223-236. 
Hunt, J. H \& Amdam, Gro. V. 2005. Bivoltism as an Antecedent to Eusociality in the Paper Wasp Genus Polistes. Science. 308: 264-267.

Jeanne, R. L. 1970. Note on bate (Phylloderma stenops) praying upon the brood of a social wasp. Jour. Mamal. 51: 624-625.

Jeanne, R. L. 1972. Social biology of the neotropical wasp Mischocyttarus drewseni. Bull. Mus. Comp. Zool. 144 (3): 63-150.

Jeanne, R.L., 1975a. The adaptiveness of social wasp nest architecture. Quart. Rev. Biol. 50:267-287.

Jeanne, R.L., 1975b. Behavior during swarm movement in Stelopolybia areata (Hymenoptera: Vespidae). Psyche 82:259-264.

Jeanne, R. L. 1979. A latitudinal gradient in rates of ant predation. Ecology. 60: 12111224.

Jeanne, R. L. 1980. Evolution of social behavior in the Vespidae. Annual Review of Entomology. 25: 371-395.

Jeanne, R. L. 1981. Chemical communication during swarm emigration in the social wasp Polybia sericea (Olivier). Animal Behaviour. 29: 102-113.

Jeanne, R. L. \& Post. D. C. 1982. Richards' gland and associated cuticular modifications in social wasps of the genus Polybia (Hymenoptera: Vespidae: Polistinae: Polybiini). Insects Sociaux. 29: 280-294.

Jeanne, R. L., Downing, H.A., \& Post, D.C. 1983. Morphology and function of sternal glands in polistine wasps (Hymenoptera: Vespidae). Zoomorphology 103: 149164.

Jeanne, R. L. 1986. The organization of work in Polybia occidentalis: The costs and benefits of specialization in a social wasp. Behav. Ecol. Sociobiol. 19: 333-341.

Jeanne R. L. 1991. The swarm-founding Polistinae. In: The Social Biology of Wasps (K.G. Ross \& R.W. Matthews, Eds.), Cornell University Press, Ithaca, NY. 191231pp.

Jeanne, R. L. 1995. Non-size-based morphological castes in a social insect Naturwissenschaften 82: 296-298.

Jeanne, R. L. 2003. Social complexity in the Hymenoptera, with special attention to the wasps. In: Tomonori Kikuchi, Noriko Azuma, \& Seigo Higashi (Eds.) Genes, Behaviors and Evolution of Social Insects, pp. 81 130. Proceedings of the XIVth Congress of the IUSSI, Sapporo, Japan, 2002. Hokkaido University Press, Sapporo. 
Kudô, K., Tsujita, S., Tsuchida, K., Goi, W., Yamane, Sô. Mateus, S., Itô, Y., Myiano, S., \& Zucchi, R. 2005. Stable relatedness structure of the large-colony swarmfounding wasp Polybia paulista. Behav. Ecol. Sociobiol. 58: 27-35.

Kukuk, P. F. 1994. Replacing the terms 'primitive' and 'advanced': new modifiers for the term 'eusocial'. Anim. Behav. 47: 1475-1478.

London, K. B. \& Jeanne, R. L. 1998. Envelopes Protect Social Wasps' Nests from Phorid Infestation (Hymenoptera: Vespidae, Diptera: Phoridae). Journal of the Kansas Entomological Society 71 (2): 175-182.

Machado, V. L. L. 1972. Aspectos da biologia de Protopolybia pumila (Saussure, 1863) (Hymenoptera: Vespidae). Dissertação de mestrado. ESALQ - USP. 83p.

Machado, V. L. L 1974. Aspectos biológicos de Protopolybia exigua var. exjgua (Saussure, 1854) (Hymenoptera - Vespidae). Tese de doutorado: ESALQ - USP. 105p.

Mateus, S. \& Noll, F. B. 1997. Nectarinella xavantinensis, a new neotropical social wasp (Hymenoptera: Vespidae; Polistinae). Journal of the New York Entomological Society. 105\{1-2): 45-49.

Mateus, S. Noll, F. B. \& Zucchi, R. 1997. Morphological caste differences in neotropical swarm-founding polistinae wasps: Parachartergus smithii (Hymenoptera: Vespidae). Journal of the New York Entomological Society. 105(3-4): 129-139.

Mateus, S. Noll, F. B. \& Zucchi, R. 1999. Caste differences and related bionomic aspects of Chartergellus communis, A Neotropical Swarm-founding Polistinae Wasp (Hymenoptera: Vespidae: Polistinae: Epiponini). Journal of the New York Entomological Society. 107(4): 390-405.

Mateus, S. Noll, F. B. \& Zucchi, R. 2004. Caste Flexibility and Variation according to the Colony Cycle in the Swarm-founding Wasps, Parachartergus fraternus (Gribodo) (Hymenoptera: Vespidae: Epiponini). Journal of the Kansas Entomological Society: Vol. 77, No. 4, pp. 470-483.

Maschwitz, U. W. J. \& Kloft, W. 1971. Morphology and function of the venom apparatus of insects-bees, wasps, ants, and carterpillars. In Bücherl E. E. (Eds.): Venomous Animals and Their Venoms: pp. 1-60. Academic Press, New York and London.

Matsuura, M., 1991. Vespa and Provespa. In: The Social Biology of Wasps (K.G. Ross \& R.W. Matthews, Eds.), Cornell University Press, Ithaca, New York. 232-262 pp.

Matsuura M. 1999. Size and composition of swarming colonies in Provespa anomala (Hymenoptera, Vespidae), a nocturnal social wasp. Insectes Sociaux 46: 219-223.

Maynard Smith, J. 1964. Group selection and kin selection. Nature. 201: 1145-1147. 
Michener, C.D. 1969. Comparative social behavior of bees. Annu. Rev. \&it. 14: 299-342.

Michener, C. D. 1990. Classification of the Apidae. University of Kansas Science Bulletin 54: 75-153.

Naumann, M. G. 1970. The nesting behavior of Protopolybia pumila in Panama (Hymenoptera, Vespidae). Kansas, 182p Ph. D. Thesis. University of Kansas, Lawrence.

Naumann, M. G., 1975. Swarming behavior: evidence for communication in social wasps. Science. 189: 642-644.

Nascimento, F. S. 2003. Diversidade da organização social nos Epiponini (Hymenoptera, Vespidae, Polistinae). Dissertação de Doutorado, Departamento de Biologia, FFCLRP-USP. Ribeirão Preto SP. - USP, 95 p.

Nascimento, F. S., Tannure-Nascimento, I. \& Zucchi, R. 2004. Behavioral mediators of cyclical oligogyny in the Amazonian swarm-founding wasp Asteloeca ujhelyii (Vespidae, Polistinae, Epiponini). Insectes Sociaux. 51: 17-23.

Noda, S. C. M., Shima, S. N. \& F. B. Noll. 2003. Morphological and physiological caste differences in Synoeca cyanea (Hymenoptera, Vespidae, Epiponini) according to the ontogenetic development of the colonies. Sociobiology. 41: 547-570.

Noirot, C. \& Quennedey, A. 1974. Fine structure of insect epidermal glands. Annu. Rev. Entomol. 19: 61-80.

Noll, F. B. 1995. Diferenciação inter-castas e sua variação conforme o ciclo de desenvolvimento em colônias de algumas espécies de Polybia (Hymenoptera, Vespidae, Epiponini). Dissertação de mestrado, FFCLRP - USP.

Noll F. B., Mateus S, \& Zucchi R. 1996. Morphological caste differences in neotropical swarm-founding polistinae wasps. V- Protopolybia exigua exigua (Hymenoptera: Vespidae). Journal of the New York Entomological Society 104 (1): 61-68.

Noll, F. B., Simões, D. \& Zucchi, R. 1997. Morphological caste differences in the neotropical swarm-founding Polistine wasps: Agelaia m. multipicta and A. p. pallipes (Hymenoptera Vespidae). Ethology Ecology \& Evolution 9: 361 - 372.

Noll, F. B. \&. Zucchi, R. 2000. Increasing caste differences related to life cycle progression in some Neotropical swarm-founding polygynic wasps (Hymenoptera: Vespidae: Epiponini). Ecol. Ethol. Evol. 12(1): 43-65.

Noll, F. B. 2000. Uma análise da evolução das castas nos Epiponini (Hymenoptera: Vespidae), Dissertação de Doutorado, Departamento de Biologia, FFCLRP-USP. Ribeirão Preto - USP, 217 p. 
Noll, F. B. \& Zucchi, R. 2002. Castes and the influence of the colony cycle in swarm founding polistine wasp (Hymenoptera, Vespidae, Epiponini). Insectes sociaux. 48: 01-13.

Noll, F. B., Wenzel, J. W. \& Zucchi, R. 2004. Evolution of Caste in Neotropical Swarmfounding Wasps (Hymenoptera: Vespidae: Epiponini). Americam Museum Novitates, Number 3467, 24 pp.

O'Donnell, S. 1998. Reproductive caste determination in eusocial wasps (Hymenoptera: Vespidae) Annu. Rev. Entomol. 43: 323-346.

O’Donnell, S. 2001. Worker Age, Ovary Development, and Temporal Polyethism in the Swarm-Founding Wasp Polybia occidentalis (Hymenoptera: Vespidae). Journal of Insect Behavior. Vol. 14 No. 2, 201-213.

Page, R. E. \& Laidlaw, H. H. 1988. Full sisters and super sisters: a terminological paradigm. Anim. Behav. 36: 944-945.

Pardi, L. 1942a. Ricerche sui Polistini. V. La poliginia iniziale di Polistes gallicus (L.). Boll. Ist. Entomol. Univ. Bologna. 14: 1-106.

Pardi, L. 1946. Ricerche sui Polistini. VII. La "dominazione" e il ciclo ovarico annuale in Polistes gallicus (L.). Boll. Ist. Entomol. Univ. Bologna. 15: 25-84.

Platt, T. G., Queller, D. C. \& Strassmann, J. E. 2004. Aggression and worker control of caste fate in a multiple-queen wasp, Parachartergus colobopterus. Animal Behaviour, 67: 1-10.

Queller, D. C., Negrón-Sotomayor, J., Strassmann, J. E. \& Hughes, C. R. 1993. Queen number and genetic relatedness in a neotropical wasp, Polybia occidentalis. Behav. Ecol. 4: 7-13.

Queller D. C. \& Strassmann J. E. 1998. Kin selection and social insects. Bioscience 48(3): 165-175.

Ratnieks, F. L. W. \& Anderson, C. 1999. Task partitioning in insect societies. Insectes Sociaux. 46: 95-108.

Richards, O. W. \& Richards, M. J. 1951. Observations on the social wasps of South America (Hymenoptera, Vespidae). Transactions of the Royal Entomological Society of London 102: 1-170.

Richards, O. W. 1971. The biology of the social wasps (Hymenoptera, Vespidae). Biol. Rev., 46: 483-528.

Richards O. W. 1978. The social wasps of the Americas, excluding the Vespinae. London: British Museum (Natural History), VII + 580 pp.

Röseler, P. -F. \& Röseler, I. 1989. Dominance of ovariectomized foundresses of the paper wasp Polistes gallicus. Insectes Sociaux. 36: 219-234. 
Saito, F., Murakami, T. \& Kujima, J. 2004. Cryptically dimorphic caste differences in a Neotropical, swarm-founding paper wasp genus, Parachartergus (Hymenoptera: Vespidae). Entomological Science 7, 359-368.

Sakagami, S. F., Beig, D., Zucchi, R. \& Akarira, Y. 1963. Occurrence of ovary developed workers in queenright colonies of stingless bees. Rev. Bras. Biol. 23: 115-129.

Sakagami, S. F. \& Yoshikawa, K. 1968; A new ethospecies of Stenogaster wasps from Sarawak, with a comment on the valne of ethotogical characters in animal taxonomy: Ann. Zool. Jap., 41(2): 77-83.

Sakagami, S. F., Zucchi, R., Yamane, S., Noll, F. B., \& Camargo, J. M. F. 1995. Morphological Caste Differences in Agelaia vicina the Neotropical Swarm Founding Polistinae wasp with the largest colony size among social wasp (Hymenoptera; Vespidae) Sociobiology 28 (2): 207-223.

Silva, D. L. N., Zucchi, R., \& Kerr, W. W. 1972. Biological and Behavioural aspects of the reproduction in some species of Melipona (Hymenoptera, Apidae, Meliponinae). Anim. Behav. 20 (1): 123-132.

Simões, D. 1977. Etologia e diferenciação de casta em algumas vespas sociais (Hymenoptera, Vespidae). Dissertação de doutorado, FMRP-USP. Depto. de Genética e Matemática aplicada a biologia, 182p.

Simões, D. \& Zucchi, R. 1980. Bionomics of Protopolybia exigua exigua (De Saussure) IAge polyethysm and life-table (Hymenoptera: Vespidae: Polibiini). Naturalia, São Paulo. 5: 79-87.

Simões, D., Noll, F. B., \& Zucchi, R. 1996. Duration of Protopolybia exigua exigua (de Saussure) nests and related aspects as influenced by phorid fly infestation (Vespidae, Polistinae, Epiponini). Sociobiology 28: 121-129.

Schremmer F. 1972. Beobachtungen zur Biologie von Apoica pallida (Olivier, 1791), einer neotropischen sozialen Faltenwespe (Hymenoptera: Vespidae). Insectes Sociaux. 19: 343-357.

Shima, S. N., Yamane, S. \& Zucchi, R. 1994. Morphological Caste Differences in Some Neotropical Swarm-founding Polistinae Wasps I. Apoica flavissima (Hymenoptera, Vespidae). Jpn. J. Ent., 62(4): 811-822.

Shima, N. S., Noll, F. B., Zucchi, R. \& Yamane, S. 1998. Morphological caste differences in the neotropical swarm-founding Polistine wasps IV: Pseudopolybia vespiceps, with a preliminary considerations on the role of intermediate females in the social organization of the Epiponini (Hymenoptera, Vespidae). J. Hym. Res. 7(2): 280-295.

Shima, N. S., Noll, F. B. \& Zucchi, R. 2003. Influence of the colony cycle on physiological and morphological caste variation in the perennial neotropical 
swarm-founding social wasp, Protonectarina sylveirae (Hymenoptera, Vespidae, Epiponini). Sociobiology 42 (2): 449-466.

Smith, A. R., O'Donnell, S. \& Jeanne, R. L. 2001. Correlated evolution of social structure and sternal glands in eusocial wasps (Hymenoptera: Vespidae). Evolutionary Ecology Research 3: 331-344.

Smith, A. R., O'Donnell S., \& Jeanne R. L. 2002. Evolution of swarm communication in eusocial wasps (Hymenoptera: Vespidae). Journal of Insect Behavior 15: 751-764.

Solís, C. R., Hughes, C. R., Klingler, C. J., Strassman, J. E. \& Queller, D. C. 1998. Lack of kin discrimination during wasp colony fission. 1998. Behavioral Ecology 9:172176.

Spradbery, J. P. 1991. Evolution of queen number and queen control. In: K. G. Ross \& R. W. Matthews (editors), The Social Biology of wasps: 336-388. Ithaca, NY: Cornel University Press.

Starr, C. K., 1990. Holding the fort: colony defense in some primitively social wasps. In: Insect Defenses, Adaptive Mechanisms and Strategies of Prey and Predators (D.L. Evans and J.O. Schmidt, Eds.), State University of New York Press, Stony Brook. pp. 421-463.

Starr, C. K. 1991. The Nest as the Locus of Social Life. In: K. G. Ross \& R. W. Matthews (editors), The Social Biology of wasps: 520-539. Ithaca, NY: Cornel University Press.

Strassmann, J. E. \& Meyer, D. C. 1983. Gerontocracy in the social wasp, Polistes exclamans. Animal Behaviour, 31: 431-438.

Strassmann, J. E., C. R. Hughes, D. C. Queller, S. Turillazzi, R. Cervo, S. K. Davis, \& K. F. Goodnight 1989. Genetic relatedness in primitively eusocial wasps. Nature 342: 268-270.

Strassmann J. E., Queller D. C., Solis C. R., \& Hughes C. R. 1991. Relatedness and queen number in the neotropical wasp, Parachartergus colobopterus. Anim. Behav. 42: 461470 .

Strassmann, J. E., Solis, C. R., Hughes, C. R., Goodnight, K. F., \& Queller, D. C. 1997. Colony life history and demography of a swarm founding social wasp: Behav. Ecol. \& Sociobiol. 40: 71-77.

Strassmann J. E., Goodnight K. F., Klingler, C. J. \& Queller, D. C. 1998. The genetic structure of swarms and the timing of their production in the queen cycles of neotropical wasps. Molecular Ecology 7: 709-718.

Strassmann, J. E., Sullender, B. W. \& Queller, D. C. 2002. Caste totipontency and conflict in a large-colony social insect. Proc. R. Soc. Lond B. $269: 263-270$.

Turillazzi, S. 1991. The Stenogastrinae. In: The Social Biology of Wasps In: K.G. Ross \& 
R.W. Matthews, Eds., Cornell University Press, Ithaca, New York. pp. 74-98.

Wenzel, J. W. 1987 Ropalidia formosa, a nearly paper wasp from Madagascar (Hymenoptera, Vespidae). Jour. Kansas Ent. Soc. 60(4) : 549-556.

Wenzel, J. W., 1991. Evolution of nest architecture. In: The Social Biology of Wasps In: K.G. Ross \& R.W. Matthews, Eds., Cornell University Press, Ithaca, New York. pp. $480-519$.

Wenzel, J. W. 1993. Application of the biogenetic law to behavioral ontogeny: a test using nest architecture in paper wasps. Jour. Evol. Biol. 6: 229-247.

Wenzel, J. W. 1998. A generic key to the nests of hornets, yellowjackets, and paper wasps worldwide (Vespidae: Vespinae, Polistinae). American Museum Novitates 3224: 1-39.

Wenzel, J. W. \& Carpenter, J. M. 1994. Jn: P. Eggleton, \& R. Vane-Wright (eds.), Comparing methods: adaptive traits and tests of adaptation. Phylogenetics and Ecology, pp. 79-101. Academic Press, London.

Wheeler, D. E. 1986. Developmental and physiological determinants of caste in social Hymenoptera: evolutionary implications. American Naturalist. 128: 13-34.

Wheeler, D. E. 1991. The developmental basis of worker castes polymorphism in ants. American Naturalist 138: 1218-1238.

West-Eberhard, M. J. 1969. The social biology of polistine wasps. Misc. Publ. Mus. Zool. Univ. Michigan 140: 1-101.

West-Eberhard, M. J. 1975. The evolution of social behavior by kin selection. Quart. Rev. Biol. 50: 1-33.

West-Eberhard, M. J. 1973. Monogyny in "polygynous" social wasps. Proc. 7th Int. Cong. Int. Union Study Soc. Insects, pp. 396-403.

West-Eberhard, M. J. 1977. The establishment of reproductive dominance in social wasp colonies. Proc. 8Th Int. Cong. Int. Union Study Soc. Insects, pp. 223-227.

West-Eberhard, M. J. 1978a. Temporary queens in Metapolybia wasps: nonreproductive helpers without altruism? Science. 200: 441-443, 1978a.

West-Eberhard, M. J. 1978b. Polygyny and the evolucion of social behavior in wasps. Jour. Kansas Entomol. Soc., 51(4): 832-856, 1978 b.

West-Eberhard, M. J. 1981. Intragroup selection and the evolution of insect societies. In Natual Selection and social behavior (ed. R.D. Alexander \& D.W. tinkle), pp. 3-17. Chiron Press, New York.

West-Eberhard M. J. 1982. The nature and evolution of swarming in tropical social wasps (Vespidae, Polistinae, Polybiini), pp. 97-128. In: Jaisson P., Edit. Social insects in the tropics, Vol. 1. Paris: Université de Paris-Nord. 
West-Eberhard, M. J. 1986. Dominance relations in Polistes canadensis (L.), a tropical social wasp. Monit. Zool. Ital. (N.S.) 20: 263-281.

West-Eberhard, M. J. 1987. Observations of Xenorhynchium nitidulum (Fabricius) (Hymenoptera, Eumeninae), a primitively social wasp. Psyche 94: 317-323.

West-Eberhard, M. J. 1989. Scent-trail diversion, a novel defense against ants by tropical social wasps. Biotropica. 21: 280-281.

West-Eberhard, M. J. 1991. Sexual Selection and Social Behavior. Man and Beast Revisited, M.H. Robinson and L. Tiger.: 159-172.

Wilson, E. O. 1971. The insect societies. Belknap Press. Harv. Univ. Press. Camb. Mass., 548p.

Yoshikawa, K., Ohgashi,. R. \& Sakagami, S.F. 1969. Preliminary report on entomology of the Osaka City University Sth. Expedition to Southeast Asia 1966. Nature and Life SE Asia, 6: 153-182.

Zucchi, R. 1973. Aspectos bionômicos de Exomalopsis aureopilosa e Bombus atratus incluindo considerações sobre a evolução do comportamento social (Hymenoptera, Apoidea). Tese de Doutoramento 172pp. Faculdade de Filosofia Ciências e Letras de Ribeirão Preto - USP.

Zucchi, R., Yamane, S. \& Sakagami, S. F. 1976. Preliminary notes on the habits of Trimeria howardi, a neotropical communal masarid wasp, with description of the mature larva (Hymenoptera: Vespoidea). Insecta Matsumurana. 8: 47-57.

Zucchi, R., Sakagami, S. F., Noll, F. B., Mechi, M. R., Baio, M. V., Mateus, S. \& Shima, S. N. 1995. Agelaia vicina, a swarm-founding Polistinae with the largest colony size among wasps and bees (Hymenoptera, Vespidae). Journal do the New York Entomological Society. 103 (2): 129-137

Zucchi, R. 1993. Ritualized dominance, evolution of queen-worker interactions and related aspects in stingless bees (Hymenoptera: Apidae). 207-249 pp. Irr. T. Inoue \& S. Yamane (eds.). Evolution of Insect Societies.

Zucchi, R., Silva-Matos, E. V., Nogueira-Ferreira, F. H., \& Azevedo, G. G. 1999. On the cell provisioning and oviposition process (POP) of the stingless bees Nomenclature reppraisal and evolutionary considerations (Hymenoptera, Apidae, Meliponinae). Sociobiology, 34: 65-86. 